


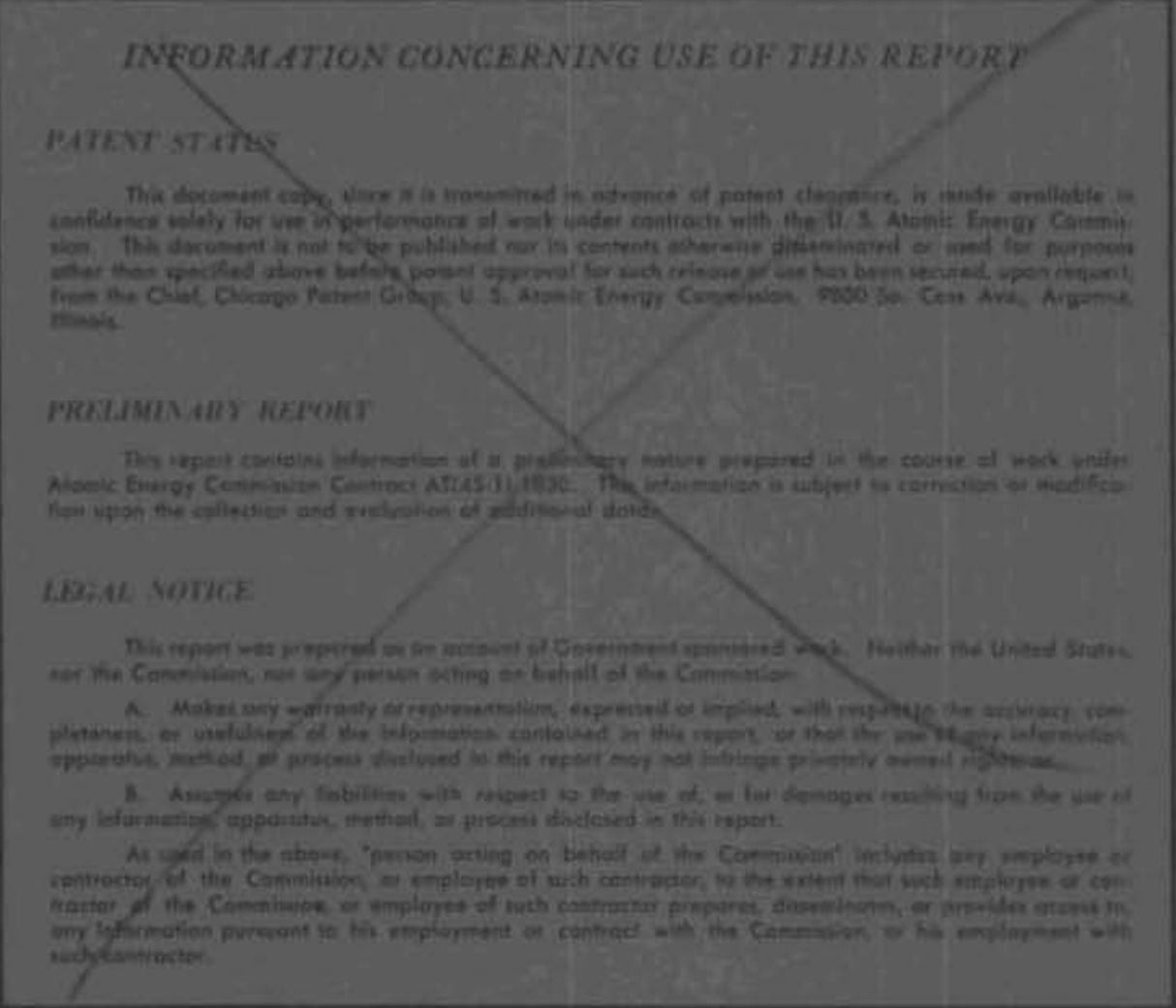

\section{PACIFIC NORTHWEST LABORATORY

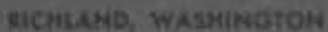 \\ operated by}

BATTELLE MEMORLAL. INSTITUTE

for the

UNITED STATES ATOMIC ENERGY COMMISSION UNDER CONTRACT AT(45-1)-1830 


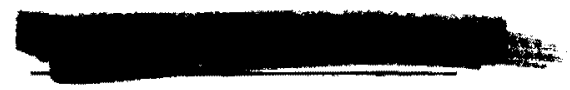

BNWL -1246

33679000616385

FAST FLUX TEST FACILITY

MONTHLY INFORMAL TECHNICAL PROGRESS REPORT

OCTOBER 1969

E. R. Astley

Project Manager

C.P. Crabuel

by C. P. Cabe11

November 7,1969

BATTELLE MEMORIAL INSTITUTE

PACIFIC NORTHWEST LABORATORIES

RICHLAND, WASHINGTON 99352 
1 


\title{
FAST FLUX TEST FACILITY \\ MONTHLY INFORMAL TECHNICAL PROGRESS REPORT \\ OCTOBER 1969
}

\begin{abstract}
This report was prepared by Battelle-Northwest under Contract No. AT(45-1)-1830 for the Atomic Energy Commission, Division of Reactor Development and Technology, to summarize technical progress made in the Fast Flux Test Facility Program during October 1969.
\end{abstract}




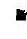

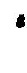

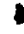




\section{CONTENTS}

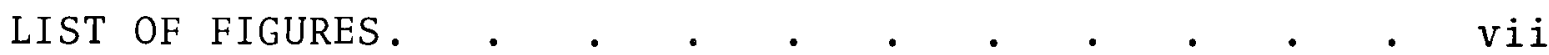

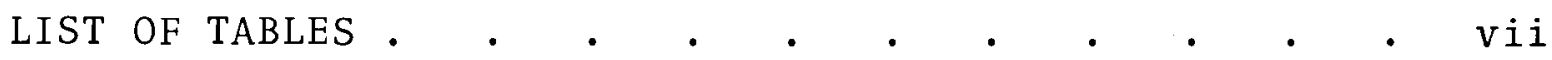

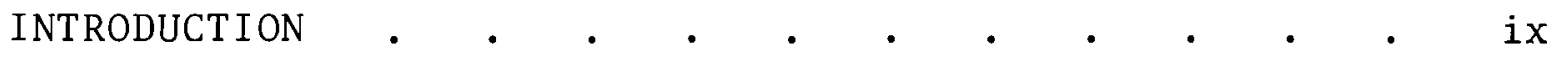
CHAPTER I.

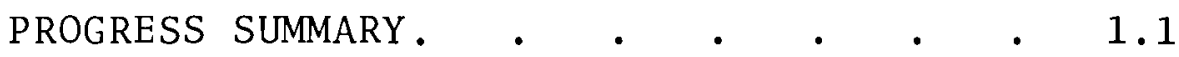

A. Structure, Site, Utilities . . . 1.1

B. Components . . . . . . . . 1.1

C. Instrumentation and Controls. . . 1.1

D. Sodium Technology . . . . . 1.2

E. Core Design . . . . . . . 1.2

F. Fuels and Materials. . . . . 1.3

G. Fue1s Recycle . . . . . . 1.3

H. Physics . . . . . . . . 1.4

I. Safety Containment Response . . . 1.4

CHAPTER II. PLANT DESIGN • • • • • • • • • • $\quad 2.1$

A. Overa11 Plant Design. . . . . 2.1

B. Structures, Utilities, and

Containment . $. \quad . \quad . \quad . \quad . \quad .9$

CHAPTER III. COMPONENTS.$\quad \cdot \quad \cdot \quad \cdot \quad \cdot \quad \cdot \quad \cdot \quad \cdot \quad 3.1$

A. Reactor Components . . . . . 3.1

B. Heat Transport Components . . . 3.5

CHAPTER IV. INSTRUMENTATION AND CONTROLS. • • • 4.1

A. FFTF I\&C Systems. • . • . . 4.1

B. Development of Sensors and Related

Equipment $. \quad . \quad . \quad . \quad . \quad . \quad 4.6$

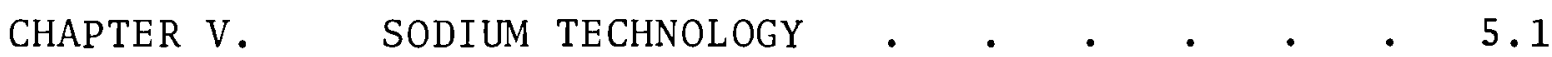

A. Analytical Methods for Sodium

and Cover Gas . $\quad . \quad . \quad . \quad . \quad . \quad 5.1$

B. Coolant and Gas Technology

Development . . . . . . 5.3

C. Operation of Sodium Facilities . . 5.7

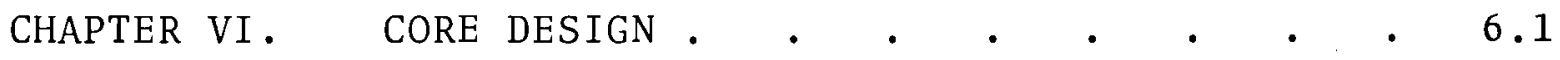

A. Core Mechanics Conceptual Design,
Development, Testing. $\quad$. $\quad$. $\quad 6.1$ 
B. Core Process Technology. . . . 6.9

C. Irradiation Test Facilities. . . 6.14

D. Other Core Design . . . . . 6.20

CHAPTER VII. FUELS AND MATERIALS EVALUATION . . . 7.1

A. Fuels and Materials Evaluation. . 7.1

B. Materials Technology . . . . 7.13

CHAPTER VIII. FUELS RECYCLE . • . . • .

A. Fuel Technology. $. \quad \cdot \quad . \quad . \quad .8 .1$

B. Cladding Technology. . . . .8 .4

C. Fuel Pin Technology. . . . $\quad$. 8.5

D. Fuel Subassembly Technology..$\quad$. 8.8

CHAPTER IX. PHYSICS..$\quad \cdot \quad \cdot \quad \cdot \quad \cdot \quad \cdot \quad \cdot \quad \cdot 9.1$

A. Core Physics . $\quad . \quad$. $\quad . \quad$. $\quad .9 .1$

B. Radiation and Shielding. . . . 9.10

CHAPTER X. SAFETY . . . . . . . . . . 10.1

A. Plant Safety Analysis . . . . 10.1

B. Analysis of Hypothetical

Accidents . . . . . . 10.2

APPENDIX A AUTHOR CODES FOR FFTF PERIODIC

TECHNICAL REPORTS • . • . • • . . A.1 


\section{LIST OF FIGURES}

\begin{tabular}{|c|c|c|}
\hline $6 . \mathrm{A} .1$ & Simulated Core Mode1 SCM P1an & 6.5 \\
\hline $6 . \mathrm{A} .2$ & Simulated Core Mode1 SCM Evaluation & 6.6 \\
\hline $6 . \mathrm{D} .1$ & Advanced Core Study Oxide Fuel & 6.25 \\
\hline $6 . \mathrm{D} \cdot 2$ & Advanced Core Study Carbide Fue 1 & 6.26 \\
\hline $6 . \mathrm{D} .3$ & Advanced Core Study Required Reactor Changes & 6.27 \\
\hline $7 . A .1$ & $\begin{array}{l}\text { Iron, Nickel, and Chromium Composition } \\
\text { of Deposits in Fuel Crack Versus Distance } \\
\text { from Cladding }\end{array}$ & 7.6 \\
\hline $7 . A .2$ & $\begin{array}{l}\text { Iron-to-Nicke1 and Chromium-to-Nicke } 1 \\
\text { Ratios in Deposits in Fuel Crack Versus } \\
\text { Distance from Cladding }\end{array}$ & 7.6 \\
\hline $9 . A .1$ & FTR- 2 Radial Reactor Rates, ${ }^{238} \mathrm{Pu}$ & 9.3 \\
\hline $9 . \mathrm{A} .2$ & FTR-2 Radial Reaction Rates, ${ }^{238} \mathrm{U}$ & 9.4 \\
\hline .A. 3 & Radia1 Reaction Rates, ${ }^{10} \mathrm{~B}$ & 9.5 \\
\hline
\end{tabular}

\section{LIST OF TABLES}

2.I Current Design Data 2.1

6.A.I Calculated Results of Thermal Distortions 6.7

6.A.II 2-MW Closed Loop Testing Requirements 6.16

6.D.I Advanced FFTF Core Characteristics 6.21

6.D.II Reactor Changes Required for Advanced Cores 6.22

6.D.II Ful1 Performance Oxide Fueled Core 6.23

6.D.IV Full Performance Carbide Fueled Core 6.24

7.A.I Summary Status of Irradiation Experiments Conducted Under Task FP-6

7.2

7.A.II Measurement and Analysis of Fission Gas from $B N W-1-1,1-2,1-3$ and $1-5 \quad 7.4$

7.A.III Iron, Nicke1, and Chromium Content of Metalic Deposits Not in Cracks in Fue 1 Pin PNL 1-6-F

7.A.IV Irradiation History and Postirradiation Properties of Specimens from PNL-59 Series Fue 1 Pins

7.A.V GETR Capsule Calculated Performance 7.8 
BNWL -1246

9.A.I Fue1 Edge Worths, FTR-2 on ZPPR

9.2

9.A.II Calculated Characteristics and Values of Material Compositions

9.7

9.A.III Summary of Uncertainties in FTR Design Parameters

9.9 


\section{FAST FLUX TEST FACILITY \\ MONTHLY INFORMAL TECHNICAL PROGRESS REPORT \\ October 1969}

INTRODUCTION

Contents of this report are arranged and presented in a new format recently developed for FFTF periodic technical reports. The new format identifies, for each item of work reported,

(1) The applicable LMFBR program plan element,

(2) The FFTF system supported by the work, and

(3) The BNW organization responsible for performance and/or management of the work.

The titles of the nine LMFBR program plan elements are used as the titles for the nine chapters in the body of the report. Each chapter is further subdivided to show specific FFTF systems and programs. Chapter II (Plant Design) presents design data for all systems, and covers progress reporting for the electrical, structures and site systems. Chapter III (Components) gives progress reporting for the reactor vessel, nuclear controls, fuel handling, heat transport and sodium, and gas systems. Chapter IV (Instrumentation and Control) covers the corresponding FFTF systems. Chapter V (Sodium Technology) presents technical information to support design of the heat removal, irradiation testing, and the sodium and gas systems. Chapter VI (Core Design) covers the core and irradiation testing systems. Chapter VII (Fuels and Materials) gives technical information to support design of process equipment throughout the plant. Chapter VIII (Fuel Recycle) covers fuel development and the fuel examination system. Chapter IX (Physics) and Chapter $X$ (Safety) provide technical information supporting the design of the entire FFTF. 
To identify the BNW organization responsible for the performance and/or management of the work, a special 3-digit "Author Code" is listed immediately after the name of each author of each item in the report. 
CHAPTER I . PROGRESS SUMMARY

A. STRUCTURE, SITE, UTILITIES

Drilling at the FFTF site to investigate load-bearing properties of the soil has been completed. Drilling required for seismic investigations of the underlying basaltic bedrock is continuing.

B. COMPONENTS

Westinghouse was directed to increase the reactor vessel diameter from 17 to $20 \mathrm{ft}$ to permit use of a rotating plug fixed arm in-vessel fuel handling machine and separated instrument tree. The procurement documents for the reactor vesse1, head, and guard vessel are being revised to reflect the change.

The fuel duct material has been selected as $20 \%$ cold worked Type 316 SS. Contract negotiations for the fabrication of prototype fuel ducts are in progress.

Progress review meetings for IHX design study contracts with Babcock \& Wilcox, FW and WARD have revealed no insurmountable problems associated with the IHX concepts being developed for FFTF service conditions.

\section{INSTRUMENTATION AND CONTROLS}

An alpha-particle counting system, presently in use on the Hanford Atomic Project, has been chosen to monitor airborne plutonium collected on filters. This system discriminates plutonium in the presence of ${ }^{220} \mathrm{Rn}$ and ${ }^{222} \mathrm{Rn}$ by using a coincidence counting circuit.

DRDT has requested that the reference design for System 95 provide in-core neutron detector thimbles capable of being cooled to $300^{\circ} \mathrm{F}$. A study is in progress to meet this requirement. 
Resistance measurements on chrome1-alumel thermocouples which had been exposed to $\sim 3 \times 10^{21}$ nvt (fast) at EBR-II showed a negligible change in resistance in the thermal element leads.

\section{SODIUM TECHNOLOGY}

Installation of the remote flowthrough sampler was completed and sodium flow tests started. Four samples were taken successfully.

Significant amounts of ${ }^{54} \mathrm{Mn}$ were found by gamma scanning an irradiated pipe from EBR-II. These results confirm previous BNW radioisotope transport loop predictions.

\section{E. CORE DESIGN}

The formulation for the BEAM Creep Code has been completed, documented, and is being published. The general solutions developed will provide the required behavior prediction for FFTF fuel ducts.

A Study Group was established at BNW to evaluate the effect on core structures of the total reactor environment including thermal, mechanical, and structural effects from neutron induced swelling, in-reactor creep, and stress relaxation. The results of the study are being assembled into a report.

Studies are continuing to evaluate the independence requirements for the safety systems, and to define core radial restraint requirements. Fabrication of the CCTL Mark II Subassembly is in progress.

A preliminary study of an advance core for the FFTF was completed. Two fuel compositions - oxide and carbide - were described for full performance cores.

Testing requirements for the $2-\mathrm{MW}$ modular closed loops were defined to include $1400^{\circ} \mathrm{F}$ maximum sodium temperature 
at test specimen; $1200^{\circ} \mathrm{F}$ maximum sodium hot leg temperature; $400^{\circ} \mathrm{F}$ minimum cold leg temperature; $400^{\circ} \mathrm{F}$ maximum hot $1 \mathrm{eg}$ to cold leg $\triangle \mathrm{T}$; and a maximum flow rate of $\sim 290 \mathrm{gpm}$ sodium.

F. FUELS AND MATERIALS

Creep-rupture tests were made at $1100^{\circ} \mathrm{F}$ on solution treated ( $1950^{\circ} \mathrm{F} / 1 \mathrm{hr}$ ) Type 304 and 316 SS. For Type $304 \mathrm{SS}$ irradiation reduces both the rupture life and minimum creep rate. For Type 316 SS irradiation reduces the rupture life and increases the creep rate.

Nondestructive examination of EBR-II capsules showed negligible swelling in $\mathrm{B}_{4} \mathrm{C}$ and a small amount of swelling in Ta.

A remote re-encapsulation of a mock-up PNL-1 fuel pin was successfully accomplished in the 324 Building Shielded Materials Facility. This work is in preparation for re-encapsulation of a PNL-1 fuel pin previously irradiated in EBR-I I .

Intergranular failure of cladding was NOT observed in a fuel pin which had been irradiated in GETR to a burnup of $50,000 \mathrm{MWd} /$ tonneM average.

Subassemb1y PNL-2 (X032) which was discharged from EBR-II at an estimated burnup of $47,000 \mathrm{MWd} /$ tonneM was successfully disassembled and the capsules neutron radiographed. The neutron radiographs indicate cladding integrity has been retained in all 19 fuel pins. One pin, deliberately made with thin ( 0.010 in.) cladding, appeared to be bowed to an appreciable extent.

\section{G. FUELS RECYCLE}

A method has been developed for quantitative analysis of fuel pellet homogeneity through electron microprobe scanning. Availability of the new analysis method has in 
turn led to the development of an improved homogeneity specification for fuel pellets. Typical mixed oxide pellets fabricated by the BNW process readily meet the new homogeneity specification.

Approximately $5200 \mathrm{ft}$ of high quality cladding tubing has been received from one vendor who has been authorized to begin production on the balance of the $30,000-\mathrm{ft}$ order of tubing.

The criticality control program is completed and is in functional operation in the Fuel Fabrication Demonstration Facility. An extensive training program is underway to indoctrinate technicians in the use of the system.

H. PHYSICS

It was concluded that count rates in the 2 -in. diameter $235_{\mathrm{U}}$ chambers, located in the FTR reflector, will be sufficient at full shutdown $(\mathrm{k}=0.9)$ to make adequate subcritical reactivity assessments. Also, it was concluded that safety rod movements from $k=0.9$ will be an adequate scheme for establishing the neutron sensitivity of the sensors. Hence, an extraneous source in FTR is not a necessary requirement.

The predicted completion data for the FTR-2 Critical Experiments program is November 19, 1969.

The FTR-3 Critical Experiment program will follow the completion of the FTR-2 program.

I . SAFETY CONTAINMENT RESPONSE

A DBA energy release of $4000 \mathrm{MW}-\mathrm{sec}$ and a fuel vapor release of $200 \mathrm{~kg}$ was compared to a DBA energy release of $8000 \mathrm{MW}-\mathrm{sec}$ and $790 \mathrm{~kg}$ of fuel vapor reported previously. The reduced spray of fuel vapor into the cavity atmosphere reduced the initial pressure peak to 24 psig as compared to 50 psig. 
The reduced value of excursion energy about doubled the time delay for initiation of boiling of the sodium pool on the floor of the cavity. The secondary pressure peak during the boil off of sodium from the cavity and its condensation in the cells remains the same, about 18 psig.

The consequences of a hypothetical pool fire in the main containment vessel were calculated for the case of a severe excursion accident with no machinery dome. Sphere internal pressure rose rapidly to a peak of $24.0 \mathrm{psig}$ in $8.5 \mathrm{~min}$; air temperature was $1060{ }^{\circ} \mathrm{F}$ while sphere steel temperature was $120^{\circ} \mathrm{F}$. An ultimate maximum temperature of about $650^{\circ} \mathrm{F}$ for the sphere steel was indicated.

A draft of the PSAR was completed in October for submission to the CCB. However the Commission requested a 2 months delay in portions of the PSAR for re-evaluation of the basis for containment. 


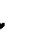

.

.

,

$\mathbf{x}$

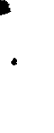




\section{CHAPTER II. PLANT DESIGN}

(See Appendix A for List of Author Codes Used in this Report) A. OVERALL PLANT DESIGN

This section is presented in the form of Table 2.I as follows.

\section{TABLE 2.I. Current Design Data}

Summary of Principal Concept Characteristics and Data as of 10/16/69 - W. M. Noble (952)

Reactor Systems (31000)

\section{Genera1 Plant Data}

1. Core Arrangement

2. Design life

3. Peak flux

4. Total power, initia1

5. Reactor coolant

6. Core volume

7. Total reactor flow

8. Reactor pressure drop design maximum

9. Reactor bulk inlet temperature initial

$$
\text { ultimate }
$$

10. Reactor bulk outlet temperature initial core

years
$\mathrm{n} / \mathrm{cm}^{2}-\mathrm{sec}$
$\mathrm{MW}_{\mathrm{t}}$

liters

$$
\text { vertical }
$$

20

1

$7.2 \times 10^{15}$

400

sodium

1033

$$
\mathrm{ga} 1 / \mathrm{min}
$$

42,240 initial 43,290

psi

145

${ }^{\circ} \mathrm{F}$

600

750

1

design maximum and ultimate

${ }^{\circ} \mathrm{F}$

850

1050

11. Core temperature rise average initial

$$
\text { ultimate }
$$

design maximum

12. Reactor cover gas
300

350

400

argon

\footnotetext{
(a) 1-Baseline data.

2 - Current accepted reference design value.

3 - Contractor assumed design values.
} 
TABLE 2.I. (contd)

Units Values Status (a)

Physics Data

1. Delayed neutron fraction

0.003

2

2. Neutron 1ifetime

seconds

$4.0 \times 10^{-7}$

3. Doppler

$\mathrm{T}(\mathrm{dk} / \mathrm{dt})$

$-0.004$

4. Power density, peak

MW/1 iter

0.75

2

5. Power distribution (peak/ average)

radial

1.40

2

axial

1.24

2

tota1

1.74

2

Core (3103)

1. Number of core lattice positions

2. Number of driver fue 1 subas semb 1 ies

3. Number of in-core safety rods

4. Number of in-core control rods

5. Number of peripheral control rods

6. Equivalent core diameter

7. Active core height 
BNWL - 1246

TABLE 2.I. (contd)

Units Values Status(a)

8. Radial reflector

material nicke1

9. Reflector thickness axia1 inches

6

2

radial

rows

3

2

10. Fuel pin heat transfer area

$f t^{2}$

2980

11. Core coolant velocity, maximum

12. Direction of coolant flow

upward

13. Radial in-reactor shield

- Materia1

- Configuration

- Thickness

rows

14. In-core open test positions

- Number with contact instrumentation

- With proximity instrumentation *

1

- Power

- Coolant flow rate

- Test assembly length

Same as driver fue 1 as semb $1 y$

* One open test position will have superior accessibility. Driver fuel positions can be used as open test positions with limited accessibizity. 
TABLE 2.I. (contd)

\begin{tabular}{lll} 
Units & \multicolumn{1}{c}{ Values } & Status (a) \\
- coolant & $\begin{array}{l}\text { Same as } \\
\text { driver fuel } \\
\text { assembly }\end{array}$ \\
- test assembly cross & $\begin{array}{l}\text { Same as } \\
\text { driver fuel } \\
\text { assembly }\end{array}$
\end{tabular}

Driver Fuel (31037)

1. Fuel composition 18 to 26 wt\%

$\mathrm{PuO}_{2}$

74 to

$82 \mathrm{wt} \% \mathrm{UO}_{2}$

2. Cladding material

Type 316 SS 1

3. Linear heat generation

rate, average (at $90 \%$

total power $\mathrm{kW} / \mathrm{ft} \quad 7.0$

4. Overpower factor

1.20

2

5. Peak linear heat generation at overpower (at $90 \%$

total power)

$\mathrm{kW} / \mathrm{ft}$

14.6

2

6. Target burnup, average

MWd/tonneM $\quad 45,000$

2

7. Cladding heat

transfer

coefficient

\section{$\mathrm{Btu} / \mathrm{hr}-$}

${ }^{\circ} \mathrm{F}-\mathrm{ft}^{2} \quad 37,500$

2

8. Maximum fuel temperature (steady state)

${ }^{\circ} \mathrm{F}$

4230

2

9. Fuel assembly

length

feet

12

2

10. Fuel geometry

Hexagonal

pin cluster 


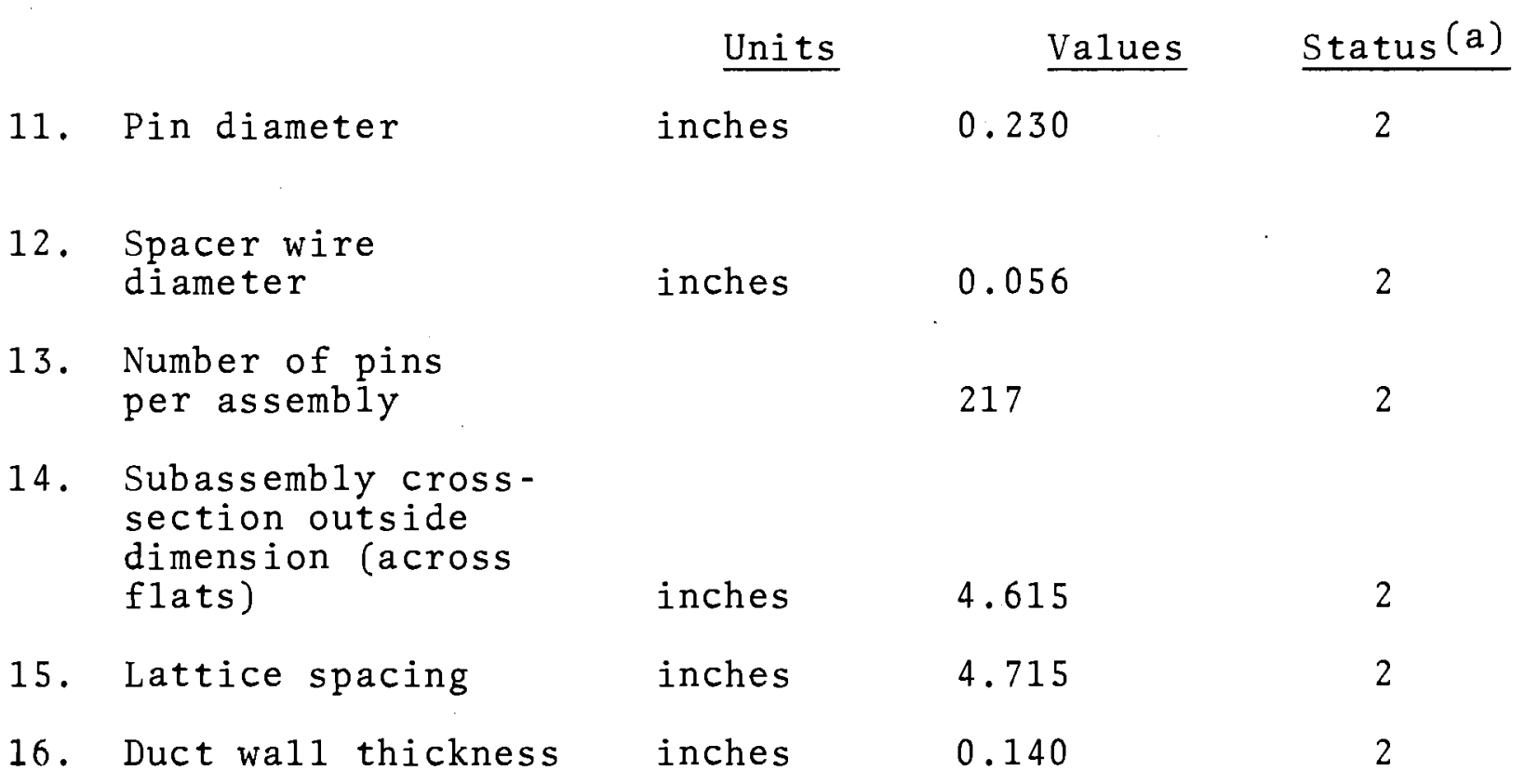

Vessels and Shields (3104)

1. Reactor Vesse1 (31045)

$\begin{array}{llll}\text { - Diameter feet } & 20 & 2\end{array}$

$\begin{array}{llll}\text { - Height feet } & 50 & 2\end{array}$

- Wall thickness inches 2

- Wa11 fluence, tota1 $\left(\right.$ at $\left.1000^{\circ} \mathrm{F}\right)$ nvt $2 \times 10^{22} 2$

- Material 304 SS 1

2. Cover Shield

- Material

low a11oy

steel

- Thickness

feet of stainless stee 1 


\section{TABLE 2.I. (contd)}

\begin{tabular}{|c|c|c|}
\hline Units & Values & Status (a) \\
\hline $\begin{array}{l}\text { feet of } \\
\text { thermal } \\
\text { baffling }\end{array}$ & 1.5 & 2 \\
\hline $\begin{array}{l}\text { feet of cellular } \\
\text { stainless steel }\end{array}$ & $\begin{array}{l}1.5 \\
\text { argon, } \\
\text { helium } \\
\text { or } \mathrm{Na}\end{array}$ & 2 \\
\hline
\end{tabular}

Heat Transport System (32000)

1. Primary loops

- Number

3

- Primary 10op material

304 SS

- Primary loop flow (per loop) (initial) gal/min

14,080

- Pipe size OD $\times$ wall thickness inches

$20 \times 0.375 \quad 2$

2. Primary pumps

- Number

3

- Design flow rate

$\mathrm{ga} 1 / \mathrm{min}$

14,500

1

- Design pump head

feet

500

- Available net positive suction head

feet

51

1

- design temperature

${ }^{\circ} \mathrm{F}$

1050

- Speed control

wound rotor motor with 1 iquid rheostat 


\section{TABLE 2.I. (contd)}

$\underline{\text { Units }} \underline{\underline{\text { Values }} \quad \underline{\text { Status (a) }}}$

- Motor power

brake

HP

1800

2

rated

HP

2500

2

3. Intermediate heat exchangers

- Number 3

- Type

vertical shell and tube 1

- LMTD

initial

${ }^{\circ} \mathrm{F}$

85

1

ultimate

${ }^{\circ} \mathrm{F}$

99.1

- Capacity

$$
\text { initial }
$$

MW

133

1

ultimate

MW

157

1

Irradiation Testing

System (33000)

\section{Test Facilities}

1. Closed loops (33030)

- Number of positions

6

2

- Location

$$
\begin{aligned}
& 2 \text { adjacent to } \\
& \text { core center } \\
& 1 \text { at mid- } \\
& \text { radius } \\
& 3 \text { at core } \\
& \text { periphery }
\end{aligned}
$$

(1)

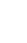


TABLE 2.I. (contd)

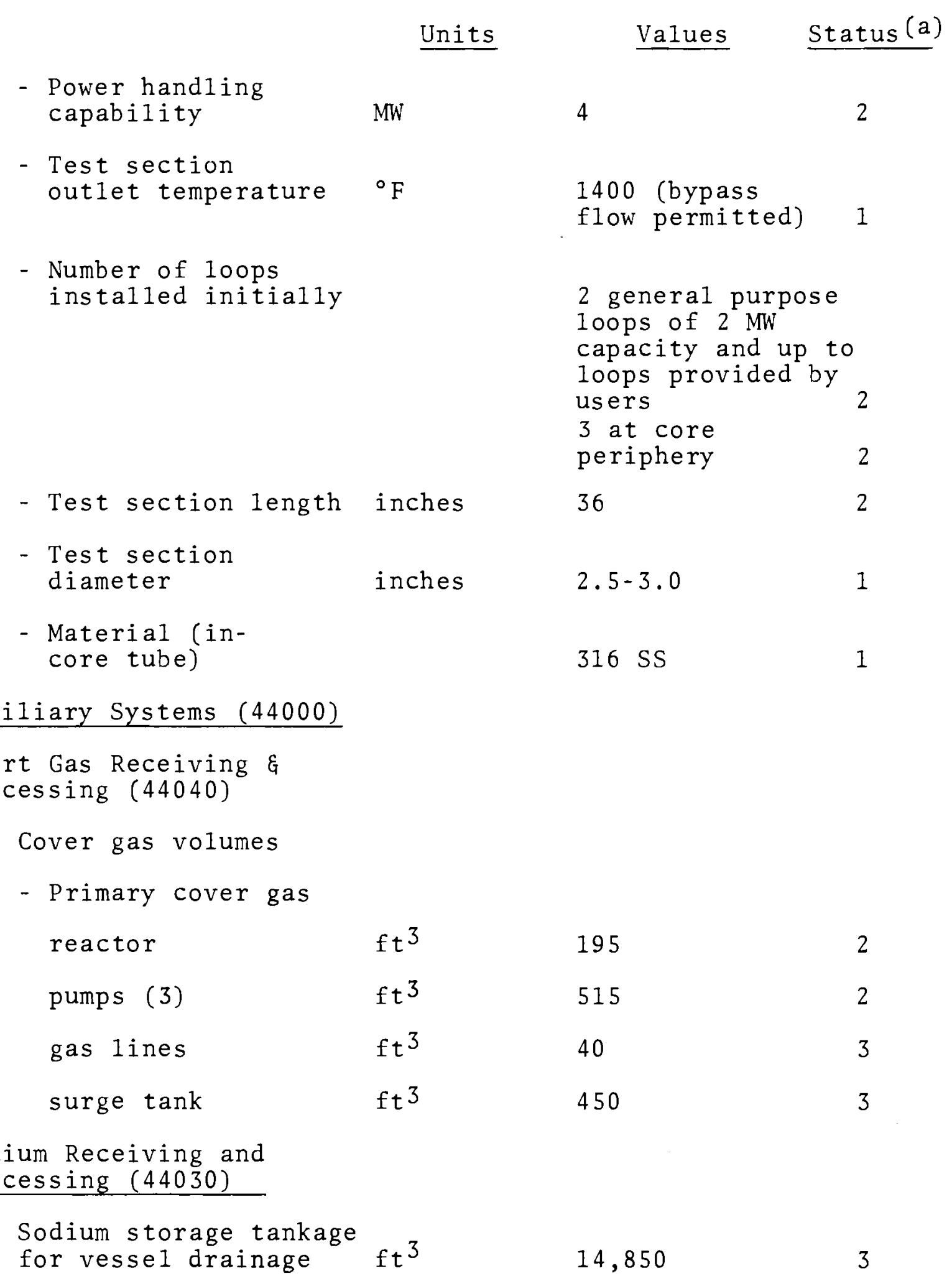


B. STRUCTURES, UTILITIES, AND CONTAINMENT

1. Structures and Containment

a. FFTF Site Investigation

E. M. Johnston (940)

The FFTF site investigation is in progress; Hatch Drilling Company is employing two drilling rigs to expedite the work. Drilling to $\sim 220 \mathrm{ft}$ (required to investigate the load-bearing properties of the site) has been completed. Drilling to bedrock at $\sim 500 \mathrm{ft}$ is continuing in order to make a seismic investigation.

b. Containment

The revised RFP for the containment vessel has been rewritten by Bechtel, and the revised document is being distributed for final review.

2. Utilities

E. M. Johnston (940)

Bechtel was requested to prepare a plan of action for prospective FFTF use of a Savannah River Plant Transformer, four Hanford 13.8 to $2.4 \mathrm{kV}$ transformers, as we 11 as $230 \mathrm{kV}$ transmission line material and $13.8 \mathrm{kV}$ switch gear also available at Hanford. 


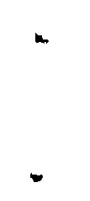




\section{CHAPTER III . COMPONENTS}

(See Appendix A for Author Codes Used in this Report)

A. REACTOR COMPONENTS

1. Fuel Ducts

W. F. Brown (AOO)

[Work sponsored by J. C. Tobin (960)]

a. Duct We1ding Development

The conceptual design for the automatic duct welding system has been completed. Detail design is approximately $50 \%$ complete. Hardware fabrication for the duct fixture has been started.

\section{b. Wear Pad Attachment}

Studies were continued on the resistance welding of aged Incone 178 to stainless stee1. Two series of welds were made on aged Inconel 718, $0.060 \mathrm{in}$. thick, to annealed Type $304 \mathrm{SS}$, 0.143 in. thick. One series was directed to the study of the effects of current, time, weld pressure, forge pressure and time of forge application on cracking in welds with fused nuggets. The second series was directed to the study of the effects of these same variables on the tensile shear strengths of spot weld.diffusion bonds. Preliminary evaluation of the results indicates that the extent of cracking was reduced in the second series, but that cracking still occurs when nuggets are of sufficient size to tear out of the Inconel 718 during tensile shear testing. The tensile shear strength for samples which show nugget tear was $6,000 \mathrm{lb}$, while the highest tensile shear strength for the diffusion bonded samples was 5,000 $1 \mathrm{~b}$.

Two 12 in. long hexagonal duct test sections have wear pads assembled and are ready for welding. Since it appears that spot diffusion bonds can be achieved with satisfactory strengths with no cracking and other defects, this approach will be used on the test sections. The test sections will then be subjected to thermal cycling and other tests to determine the feasibility of this attachment procedure. 


\section{c. Duct Procurement Activities}

R. N. Johnson (962)

Duct procurement contract negotiations are substantially complete with the two vendors selected for the fabrication of prototype fuel ducts. The costs and schedules established were based upon fabricating the ducts from Type 304 SS in the solution-treated condition. The choice of material and condition has been re-evaluated. However in the light of new stainless steel swelling information available, the choice of the duct material has been changed to Type 316 SS in the $20 \%$ cold worked condition. The vendors have indicated that the change may involve a slight increase in cost and schedule.

2. Reactor Vesse1

\section{a. Reactor Vessel Design}

O. W. Priebe (912)

Westinghouse revised the equipment specifications for the reactor vessel, head, guard vessel and associated equipment to conform to BNW requirements prior to proceeding with design efforts by the vessel supplier. Subsequently, the vessel diameter was changed from the reference $17-\mathrm{ft}$ diameter to $20-\mathrm{ft}$ diameter. This change will require revisions to the specifications and drawings and approval of BNW and the AEC.

Westinghouse submitted an evaluation of several potential problem areas associated with the use of Type 304 SS for the reactor vessel and established a plan of action. A reactor cavity work plan was also presented to conform with establishing cavity requirements for Bechtel Corporation.

A summary of engineering work performed by WARD was also received of the efforts on the reactor vessel, head, guard vessel and associated equipment since configuration selection in February of 1969. 
Babcock and Wilcox are devoting their conceptual study work on novel reactor vessel head designs and vessel support systems. Babcock and Wilcox plans to have potential candidate head designs available for review by November 1 .

b. Caustic Stress Corrosion

G. R. B10om (AOO)*

Tests are being conducted to estimate the potential for caustic stress corrosion cracking in the FFTF reactor guard vesse1. This Type 304 SS vessel, which will be exposed to a high temperature $96 \% \mathrm{~N}_{2}-4 \% \mathrm{O}_{2}$ atmosphere with traces of water. vapor, must be capable of recovering from four sodium spills without replacement. There are no caustic cracking data for these service conditions.

Preliminary tests used Type 304 SS fuel cladding samples in room air to approximate the actual conditions. Sensitized and unsensitized samples were painted with a 75 wt $\% \mathrm{NaOH}$ solution, pressurized internally to 800 psi with argon, and heated to $600,800,1000$, and $1200^{\circ} \mathrm{F}$ in air. The unsensitized samples were exposed for $120 \mathrm{hr}$ without failures. The sensitized samples have undergone $100 \mathrm{hr}$ of exposure without failure and will be exposed for an additional $20 \mathrm{hr}$. After exposure, the samples will be examined visually for oxidation, burst tested, and examined metallographically.

3. Nuclear Control Components

H. C. F. Ripfe1 (811)

a. $\quad \underline{C D D}$

RDT approval for the Nuclear Control Components Conceptual Design Description was received. Resolution of RDT comments is in progress.

* Reported by W. R. Wykoff 
b. Control Rod Driver Conceptual Studies

J. C. Noakes (914); W. S. Kelly, and

J. R. McBride $(\mathrm{COO})$

Results of survey of scram assist devices were issued. Final drafts of decelerator studies, drive line disconnects, stepping motor drives, and seal study were submitted for publication. Preparation of the electromechanical latch report is in progress.

\section{c. Roller Nut CRDM Testing at LMEC J. C. Noakes (914)}

The test plan was approved and the drive was shipped to LMEC. Wear testing of the drive mechanism in argon gas was approved and preparations are underway to modify the contract with Todd Shipyards to perform the test at Galveston, Texas.

\section{d. CRDM Prototype Procurement P. K. Telford (914)}

The draft issue of the technical input for the prototype roller nut drive procurement was received from Westinghouse, reviewed, and discussed to achieve a compatible 6-part format. 4. Other Reactor Components
a. Reactor Hardware Alignment Study B. G. Smith (914); F. R. Reich, and W. J. Coleman (MOO)

The final state-of-technology report describing the basic measurements and typical instruments required in the alignment and placement of reactor hardware in the FFTF and planned facilities has been completed. Review of the document will be performed during the month of October. 
b. Removable Driver Fue1 Instrument Assemb1y

R. F. Gilmore (914); and J. R. McBride (COO)

A description of the simulated test hardware, the test set up, and testing results were reported last month. The tests that were performed with the guide tube mounted in the vertical position showed that it was possible to insert the simulated instrument assembly unassisted into the guide tube and withdraw it with a force only slightly in excess of the assembly's weight.

Additional tests have been performed with the guide tube mounted in the horizontal plane. These tests gave results simular to those of the vertical tests.

c. IVHM Concept

E. J. Ruane (912)

A project decision was made that the In-Vessel Handling Machine (IVHM) will be separated in function from that of the Instrument Tree. The IVHM will be a rigid arm rotating plug design. Westinghouse is proceeding on this basis for the conceptual design, development planning, and testing for these components .

B. HEAT TRANSPORT COMPONENTS

1. Concept

a. CSDD Status

J. P. Petrek (923)

CSDD-51 is stil1 under review by Westinghouse.

b. Hybrid Simulation of the Reactor and Heat

Transport System

R. D. Benham (MOO); and A. L. Gunby (822)

The simulation of the reactor and primary hydraulics for pipe rupture studies has been completed on the Hybrid-2 machine. This program is identical to that employed on the 
UNIVAC 1108 machine with the time-consuming, DYNASAR general purpose code. The hybrid simulation operates well and will be compared in detail with the slower, more expensive code during the next report period. Large cost savings in pipe rupture computations are expected.

\section{Pumps}

W. Babcock (923)

The final report for the Westinghouse Phase II Low Capacity Pump Study was received and is being evaluated.

The project proposal for pumps was completed and is being circulated for approval. Technical documents required for the RFP are completed.

3. Piping

M. W. Cook (923)

The first draft of the C. F. Braun Piping Design Guide has been received and is currently being reviewed by BNW and Bechtel. Comments will be assembled and submitted to LMEC early in November.

Bechtel is proceeding with a piping layout and design. Results to date indicate that the primary pump inlet can possibly use a 28-in. pipe, but since this is marginal, a $30-$ in. pipe may be required.

A Bechtel study indicates an HTS piping cost reduction of only $\$ 37,500$ resulting from the temperature reduction from 1200 to $1050^{\circ} \mathrm{F}$. However, this is based only on the reduced piping length. Further savings are probable.

4. Sodium Valves

C. R. Nash (923)

The report describing Procedures and Results for Selection of Prospective Exhibit-C Primary-Valve Concept for Preliminary Design has been received from Aerojet-General Corporation and. 
is being reviaved. By means of rating sheets and through discussions in formal coordination and selection meeting, AGC selected three concepts of asolation valves and two concepts of check valves considered most pronising for the preIiminary design phase of the FFT main heat transport system. They note that no single valve concept studies met all of the requirements set fox the evaluation. The isolation ralve concepts selected are the rapered rotating-1irt-plug type the wedge-gate type, and the coaxial poppet type. The check valve concepts selpowed are the swinging gate type and the wedga gate true (pover-operated and system-pressure-sequenced). The concepts were selected by rating each ot the proposed concepts on iss relative capability to meet the work statement require ments.

The RDT Standard, Isolation Valves for Liquid Sodium Service, and an accompanying commentary were received and are beling reviewed.

5. Lmermedate Heat Exchangers

asign

L. A. Whingery $(923)$

The Work Scope for the Westinghouse (WARD) LMBBR Low capacity Inx wesign study has been modified to: (a) delete superfluous work of a nature that overlaps with the paral1e1 Babcock and Wilcox and Foster-Wheeler (TW) design studies, (b) redirect individual work tasks for more direct respon siveness to prow needs, and (c) improve the completion schedule data. It is presenty estimated that a draft of the final WARD report will be avaliable about November 15. 
Progress revicw meetung on ThX design sudy contracts have been held during the pas nonth with Babcock and Wilcox, WW, and WARD. Progress of all three contractors is proceeding essentially in accordarce with Work plan commtments. Final reports are scheruled for issuance on the following dates:

\section{Tsistaree of}

\section{Final Report}

$\begin{array}{lr}\text { Babcock and Wilcox } & 11-15-69 \\ \text { Fosterwheeler } & 12-31-69 \\ \text { Westinghouse } & 1-15-70\end{array}$

Results of wok promermed to date by the three desigra study contractors have reveared no insurmountable problems associated with the IHX concepts being developed for the FFrm service conditions.

An THX standard specification, together with FFr ordering data, is belng assembled by W (RPD) and is scleduled wor submittal in arats rom by November 1, 1969. A BNW/LMBC/RDT/W (RPD) task force review of the procurement speculdication documents is tentatively schedulad tor the week of November 3.

b. Simulation of FFIF THX

A. L. Gunby $(82)$

A study of LHX simulation approaches has been completed, extending the work reported previously. 1 The objective was to determine the Iimitations of current hybrid computer modeling for expected flow and temperature tramsitents. As before. detailed models of the THK destan of March, was9. (1660 tubes) were studied using the DNNASA code. The following areas were studied: (1) the effect of using average temperatures for material properties, (2) the effect of using constant

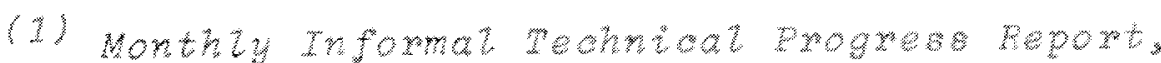
july, 1969, BNWL-1264, p. 8.1. 
walues for material propertas, (3) the offect of lumping netal wh sodium, aud (4) the effect of varying the number of axial nodes.

Mverage remperatures. Results for outhet temperature responscs showed that there was negligible difference between the two aprosenes.

Constant properies. Again, results for outet temperature responses showed neglagibue diderence (1ess than 1 o at an points an time following transient intiation).

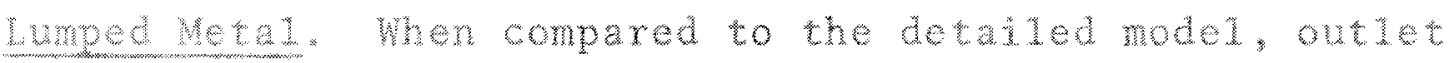
temperature tramstonts were again shown to be negligibly diflerent.

Munber of Nodes. Using the detaled nodel, the rumber of a subject to the temperature and flow imput transients, with outret resurts as expected. Accuracy increases and themal

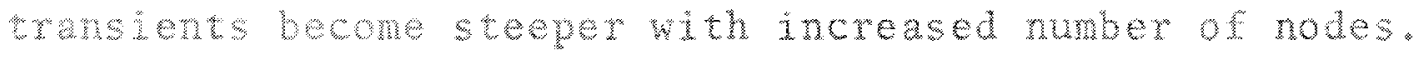
Mowever, for the pumposes of hybrid simulation control studies, oporator training, and system themal transtont check), a 4 - node model wath lumped netal and constart propatios is satisfactory.

6. Coobant and Gas Systems

R. V. DuLin $(925)$

a. System 91 - sodium Receiving and processing

Bechtel is revising System 81 schematics to reflect reduced weactor Hrs secondary storage capability and improvem ments resulting from conceptual study efrorts.

b. System 82 - Inert Gas Receiving and processing

Harvard Air Cleaning Laboratory is performing conceptual study of a bed for holdup of gases from falled and vented fuels. 
Information is also being prepared by Bechtel and Westinghouse to support a decision an plant design provisions for failed and vented fuel.

\section{c. System 83 - Auxiliary Heating and Cooling}

Further study is proceeding by Bechtel and Westinghouse to determine reactor cavity cooling requirements for this system.

\section{d. System 84 - Decontamination and Cleaning}

A conceptual description of a system to be used for decontamination of systems and components has been completed and is undergoing technical review.

\section{e. System 85 - Chemical Analysis Facility}

Guidelines for completion of a conceptual design for this facility have been provided to Bechtel. Basically, the facility would consist of a remote sampling cave in containment, and pneumatic transfer of samples to an analytical 1aboratory outside containment. This laboratory would be equipped with either remote shielded coves or shielded gloveboxes for radioactive sodium analysis. 
BNWL-1246

CHAPTER IV. MSTRUMENTATION AND CONTROLS

(sef Mppendix A for List of Author Codes Used in this Report.)

A. FFTF IRC SYSTEMS

(PBS 50,000)

1. Syster 91 - Contral Control and Data Harding system

籍. Control Koom Mockup*

M. D. ravickson (Moo)

The Phileo-fore D-30 Display system has been installed. Work 15 proceding on its interface with the Digital Equipment Corporation PDP/g computer. At present the PDP/9 computer wil Wrate correctly on the D-30 Display system in both the high and low sped modes. But it is not yet possible to transmit information on the -30 screen back to the computer. This problem is beling corrected.

During this month, two memoranda were

" "TrTh Multiplexer Evaluation," Computer Systems Development Meno $69-12$.

" "Diagram Generaturan on the Philco-Ford D-30 Color Display". Computer systoms Development Memo $69-11$.

b. System support*

6. Mastir (MOO)

Work is contining on the development of the real-time system sombre in many areas. A Task compiler/assembler program is besmg developed which wil permit use of the real-time system by personnel who are wot familisu with the detalis of system operation.

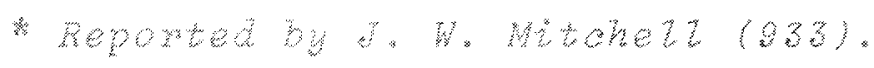


BNWL -1246

2. System 92 - Reactor and Vessed Instrument System

M. O. Rankin $(933)$

The CSDD for this system is awating DRVW approval.

3. System 93-Mant Instrumentation System

M. O. Ravkin $(933)$

Studies are in progress to reduce the number of wire runs from the transucers to the control room.

4. System 94 - puel Falure Monitoring system

a. Desigr Study - Ession Gas netector Evaluation W. Das 1032$)$

A draft of a BNW design study on the comparative gamma detection sensitivity of om tubes, gamua energy spectroscopy, and charged-wire detectors was sent to RD on October 8. Before a rinal chotee of the zamma decection method can be made, the coolart fissile contanination rate and the assumed rission gas rate of release twom a ruptured fuel pin must be defined. These two values determine the background and the signal strengths.

b. Gas DIsengagement Studies at ANL

E. Sowa (ANL) and M. J. Rieb (932)

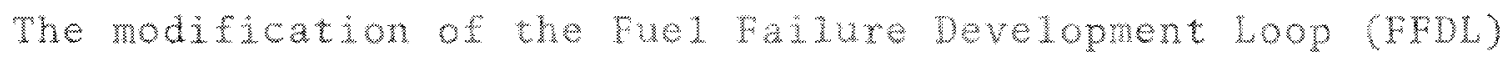
has progressed on schedule. The lower section of the out-ofvessel gas disengagex was recelved from the shops and welded into the loop in october, and the remaning parts were delivered. Capsules contanimg ${ }^{85}$ Krewe oudered from the Chemical anglneering section.

c. Concept Evaluation

R. R. Derusseau $(924)$

A task force was assembled to evaluate the cuel fallure location subsystem concept presented wh CSDD-94. The task 
force has completed this evaluation, considered alternative concepts, and presented their conclusions and proposals to department management. An early decision is expected to be made on whether to proceed with the reference sampling line concept or with altemative concepts. The status of the CSDD will be dependent upon this decision.

d. Fission Gas Samping Development

R. R. Derusseau (924)

The sample line development task, $121 \mathrm{FS}-\mathrm{A}$, has received ner approwal to build a water mockup of the sample line. The initial Work Rlan for both the water mockup and the sodium prototype loops was completed and sent to RDT for information. Westinghouse has submitted the design sketches to be used in constructing the water mockup and in designing the sodium prototype sampling line.

The development task 121 SS-C proceeded with testing a modtice model of the fission gas concentrator vortex generator). The origaral W model was successful in concentrating the gas near the generator surface, but dispersed it again before it reached the sample pickup point. The model was then modified to remove a water-gas sample from the generator surface. Early results indicate that the removal efficiency was significantly increased over the test results prior to the modification.

5. System $95-$ Fix Monitoring and Control System

a. CSDD Revision

L. W. Mcclellan (932)

Work has started on revision of CSDD-95. 
BNW -1246

b. Neutron Detector Thimble Design

L. W. McClel1an (932)

DRDT has requested that the reference dosign for system 95 provide in-come neutron detector thinblos wapable of being cooled to 300 \% An FWR project analyses of neutron detectow thimble cooling design 1 s being performed jointly by the Engineering Department and by the Reactor and punt Technology Department. These amalyses will evaluate the feasibility of thimble cooling and wil establish the requirenents and methods for cooling the assemby (including sensors and cables) to 300 F or less.

6. System 96 - Radiation Monitoring system

a. Plutonimin Monitorerig

M. O. Ramkin (933)

An alphampratcle comting system, preserty in use on the Hancord Atomic Project, has been chosen for monicoring a plutonium collected on filters. This system discriminates plutonium in the preseree of ${ }^{220} \mathrm{Rn}$ and ${ }^{22} \mathrm{Rn}$ by using a coincidence counting circuit.

7. System $99-$ Plant protection system

C. H. Strong $(043)$

a. CSDD

The CSDD for this gystem has been reviewed by the Technical Evaluation Board and submittea to the FFT Consiguration Control board.

b. Pant protection System Relidbilty Analys o. B. Monteith (821)

Some preliminary evaluations have beon made on the probability of spurious responses (calse scrams) of the pps resulting rrom equipment failures. An indtial result cor a typical 
Instrunentation subsystem is about 0.0004 false trips per year. Based on the present nominal number of so such subsystems, the expected spurious scram rate for the pPS instrumentation is about 0.02 per year. These early results do not include the effect of failures in the ac or do power supplies, the safety chrous, nor the rod release circuits.

8. Controd Analysis

a. Aarvey $(823)$

A simplified dynamic model of the FFT was simulated on the hybra computer for control studies. A simplifued transfer function detemined from mexsurements on a detailed hybrid simulation was used to represent each portion of the dynamic operations of the facility. Various types of control schemes will be studied. The model (SSYM) offers two advantages over the detaled stmulation; 1 leaves nore amplifiers free for simulating controllers and it can be operated in a faster time scale.

The multivarable-representation of the FFT has been determined so that monitored and controlled parameters appear as discrete values. A1so, the blocks were determined co yield the maximum accuracy with the simplest transforms.

S5M has been programmed on the analog computer. The rrequewey responses of the individual blocks in SSYM have been compared with those of the detalled simulation and good agreement has been achieved. The frequency response of the overall systems will be compared to ensure that SSM is an accurate representation of the ErT. 
BNWL -1246

\section{B. DEVELOPMENT OF SENSORS AND RELATED EQUIPMENT}

1. In-Reactor Thermocouples

a. Efrect of Irradiation on Resistance

N. C. Hoitink (Moo), N. S. porter (Moo), R. C. Neddle (Moo),

J. L. Jackson (AOO), and D. C. Thompson (931)

Resistance measurements on eleven 1/16 in. OD 30-in. 1ong chromel-alume1 themocouples which had been exposed to $\varsigma_{3} \times 10^{21}$ nvt (fast) at EBR-II showed a maximum change in resistance in the thermal element leads of less than 2 . This change in resistance is considered within the cxperimental error in the measuremert.

2. Pressure Sensors for Sodium Service

R. D. Crosicr (Coo), K. O. Creok (932), and M. O. Rankin (933)

a. Sodium pot Tests

Temperature testing of the following pressure tratisducers in sodium pots has continued during this reporting period:

- Consolidated Electrodynamics Corporation, Mode1 4-361-001 $S / N 2260$ (rated at 600 p and 250 psia) is being tested at $875 \circ \mathrm{F}$.

- Kaman Nuclear, Mode1 K-1900 S/N 1099 (mated at $1000^{\circ} \mathrm{F}$ and 30 psia) is being tested at $725^{\circ} \mathrm{F}$.

- Consolidated Controls Corporation, Mode1 41M7130A S/N 1442 (rated at $900^{\circ} \mathrm{F}$ and 30 psia) 15 being tested at $825{ }^{\circ} \mathrm{F}$.

Data from these tests have not yet been reduced for evaluation.

3. Low-Leve1 Neutron Fiux Instrumentation

a. Coaxial Cable Noise Level Tests

C. N. Jackson (MOO), N. C. Hoitink (MOO), N. S. Porter (Moo),

R. C. Weddle (Moo), and D. C. Thompson (931)

Low-level signals from high voltage neutron detectors are frequently obscured by "breakdown pulse noise" when coaxial 
cables supplying high voltage to the detectors are heated. Cable noise tests were made on a neutron detector wherein 19 feet of two coaxial cables were heated to $900^{\circ} \mathrm{F}$ while polarized with 400 volts. (one coaxial cable is used for high voltage supply, while the other is used for signal.) Compared to the conventional single cable configuration, noise generation in the double cable configuration was reduced by a factor of $10^{4}$. In these tests the detector was not heated. Temperatureinduced noise in single cable chambers has been a significant deterrent to high temperature operation.

\section{Reactor Envirommental Effects on Signal Cables* \\ $y$. L. Stringer (MOO)}

Experimental work on this task has been completed. A final BNWL report will be issued on all work that has not been previously reported. This report entitled Induced current and Electrical Conductivity Measurement Techniques by J. L. Stringer is expected to be issued in November as BNWL-1148. 5. In-Core flowmeter

a. Technical Support of ANL Flowmeter Development R. L. Brown (MOo) and M. J. Rieb (932)

This task is directed toward providing in-depth technical support for the primary flowmeter development effort at ANL.

During this reporting period specific procedures were proposed to ANL for the construction of several copper-wound developmental probes to accelerate the selection of the reference flowmeter probe geometry. The use of copper wire, which is readily available in a wide range of sizes, should make possible the early selection of wire size and coil form geometry. How ever, it appears that neither the copper wire nor tho nickelclad silver wire presently being used at ANL for probe

* Reported by D. G. Thompon (931). 
development purposes will be suitable for the cinal design. Information is being complied on other conductor naterials in search of nonmagnetic materials with low resistivity and an adequate high-temperature lifetime.

\section{Al Sodium Temperature and Flow Rate Probe \\ W. Dalos (932)}

The FFtF project will support a short term effort on the development of the AI Reactor Core parameter Probe (RCPP). The RCPP 1 s a device which can be inserted into a fuel duct to measure sodium temperatures and flow rates. At present, a memo purchase order (MPo) to support this work is being processed through the BNW Purchasing office. 
BNWL -1246

CHAPTER V. SODIUM TECHNOLOGY

(See Appendix A for List of Author Codes Used in this Report.)

A. ANALYTICAL METHODS FOR SODIUM AND COVER GAS*

R. L. Dition (AOO)

1. Remote Sample Development

The objective of this activity is to develop and proof test remotely operable samplers for the highly radioactive sodiun from the FETF.

The first attempt to sample the Small Components Evaluation Loop with the remotely operable bypass sampler was made. Before a full flow was established, a sodium leak was detected at the outlet conoseal. The flow was immediately stopped and no fire or damage resulted. Possible causes for the leak were investigated thoroughly before a second sampling attempt was made. This investigation revealed the most probable source of the difficulty was in the Conoseal clamping mechanism. For succeeding samples, standard Conoseal nuts were used to fasten the sample section to the sampler. With this change the next four samples have been taken without incident. About $11 / 2 \mathrm{hr}$ are necessary to leak check the sampler and preheat the lines. Flow can be easily controlled with the bypass valve. A standard operating procedure and operating check list have been prepared and used.

\section{Carbon Analysis}

Testing of the Manco guillotine as an extruder for carbon sample preparation has been completed and the device has been placed in routine use. Evaluation of the component concentrator for the trapping of traces of $\mathrm{CO}_{2}$ has been completed and the device placed in routine use. The carbon sample load has

* Reported by W. R. Wykoff (922) 
been high during the report period. Plans have been made to attach an Electron Technology Inc. helium difusion purifier to the train.

3. Laboratory for the Analyses of Alpha Contaminated Sodum

Final drawings of the air atmosphere glovebox have been completed and a cost estimate obtained with delivery scheduled for November. Roon 312 is being vacated by its present occupants and room modification plans are under development.

4. New Analytical Methods

A method for measuring calcum in sodum is being evaluated and proof cested. It involves co-precipitation of calcium with strontum oxalate followed by atomic absomption analysis of the redissolved precipitate.

A new method for measuring halogens (exclusive of $P$ ) in metallic sodium is also being evaluated. It employs a mercury complexometric titration after isolating the halogens by an amalgamation technique similar to that which is used for oxygen determinations.

5. The Analysis of Carbon Species

A precision gas chromatograph is in place and scouting experiments on carbon species measurements have started.

Initial experiments have been directed coward isolating elemental carbon. Carbon spiked sodium samples have been dis solved in either methanol or water unside an enclosed glass vessel under an inert atmosphere or vacum. The resulting solutions containing carbon particles were filtered turough Gelman olass (no binder) micron cilters, and then combined with oxygen in a standard carbon apparatus.

The blank associated with the 1.0-in. Gelman filters were found to be equivalent to about 5 micrograms of carbon. Degassing methods for lowering the blank are being considered. 
The reaction $\mathrm{C}_{(\mathrm{s})}+2 \mathrm{OH}^{-}+\mathrm{H}_{2} \mathrm{O}+\mathrm{CO}_{3}^{-}+2 \mathrm{H}_{2}(\mathrm{~g})$ reportedly interferes th aqueous dissolutions. No evidence of this has been observed in the present experiments.

\section{B. COOLANT MNO GAS TECHNOLOGY DEVELOPMENT \\ 1. Selection and Testing of In-Line Instruments* \\ R. L. Dilion ( 000$)$}

The objectives of this task are to conduct ficld tests of currenty avaliable in-1ine sodium impurity instuments and to develop mo indine instrunent system for the analysis of sodium in petp primary sodium systems.

\section{a. Carbon Meter}

Tests on the united Nuclear carbon meter continued this month. The carbon meter response to $\mathrm{Na}_{2} \mathrm{C}_{2}$ injections is being evaluated.

A calculated 10 pprn $\mathrm{C}$ equivalent $\mathrm{Na}_{2} \mathrm{C}_{2}$ was placed upstream of a cine screen in a flowthrough injection tube on the BWW Na purification loop (SPL) and produced a 10-fold increase in the carbon meter flux. It is clear that all this $\mathrm{Na}_{2} \mathrm{C}_{2}$ did not dissolve at once for the meter was still producing a high rux after one week. Yet the plux fell wapidly each time the source was valved off. The cause of this falloff is uncertain and is besug investigated.

\section{b. Oxysen Meter}

The Unuted Nuclear oxygen meter on the Sodium purification Loop produced ateady voltage (subject to the previousiy reported amoying corrections for ambient and sodium temperatures) which did not change during the carbide addition mentioned above.

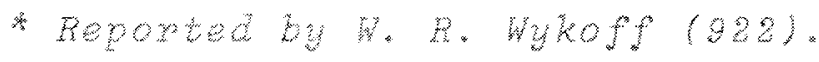


A trip was made to Brookhaven National Laboratory to discuss the changes in the reference electrode construction being worked on by BN. BNL proposes replacing the Cu/Cuo electrode with either sodim/solium oxide or aix. They prefer to operate cells containing these electrodes at $400^{\circ} \mathrm{C}$ rather than $315^{\circ} \mathrm{C}$ as used for the cu/cuo.

\section{Deconsaninasion}

R. I. Dision (AOO)

The obiectives of this task are to screen possible decontamination soutions for effectiveness. A piece of pipe from the dismantied Radioisotopes r ransport Loop $3000 \mathrm{hr}$ of service

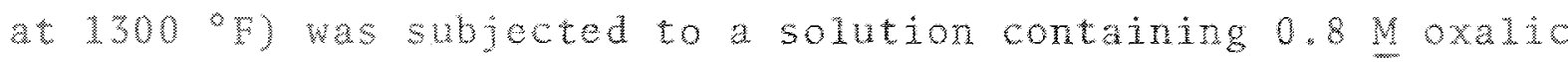
acid, $0.2 \mathrm{M} \mathrm{HF}$ and $0.015 \mathrm{MH}_{2} \mathrm{O}_{2}$ in the acid deconamination 1oop. Decontamination and we cunction of time. After 8.5 hr of exposure to the solution at about $95^{\circ} \mathrm{C}$, the decontamination factor was 2 for 60 Co and 6.7 tor 54 Mn: calculated uniform penetration of the pipe was 1. $31 \mathrm{~min}$

These decontamination factors are well below the values sought (DP of 100 to 200). The test is contuming to determine 重等 Ionger exposure will improve the DF.

3. Sodium Erosion Tests

A. $\mathrm{Webb}(954)$

The $\mathrm{T}-\mathrm{t}$ test series, which includes $\mathrm{T}-1 \mathrm{~B}$ (now at LMC

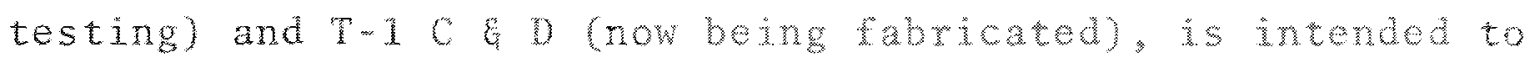
explore sodium crosion effects at high velocity in the wel duct tip/receptacle area. The T-1 B test apparatus consists of five modules having sodium velocities ranging from 30 to $70 \mathrm{ft} / \mathrm{sec}$; the T-1 D test apparatus is a follow-on test consisting of two modules having sodium velocities of 90 and

* Reported by W. R. Whopf (922). 
$100 \mathrm{ft} / \mathrm{sec}$; the T-1 C assembly consists of testing one of the T-1 D modules in water for hydraulic similitude purposes prior to the sodium test. In the series, the annular space between the fuel duct tip and the mating receptacle on the lower tubesheet will be tested as well as the fuel duct/receptacle seat. High velocity sodium has been found by other investigators to erode stainless steels under certain conditions.

Fabrication of the T-1 C and D test apparatus was begun in September but was suspended pending configuration changes. The work has been resumed with most machining operations completed and piping preparation beginning in early october.

During preparatory activities at LMEC, metallic particles were discovered in the $\mathrm{T}-1$ B Test Apparatus header piping. The headers were examined carefully and subsequent cleaning which included vibration, vacuuming, and swabbing was successfully accomplished on October 9, 1969. LMEC was authorized to resume preparatory activities, with $\mathrm{T}-1$ B testing to be initiated on October 24, 1969.

\section{Development of Power Controllers* \\ R. L. Dillon (A00)}

The development of low cost power controllers is continuing. Presently the controllers are rated at $3.6 \mathrm{kVA}$ and required about 16 in. $^{2}$ in panel area and are equipped with an ammeter. The objectives are to improve the controllers by:

- Reducing the area to $\sim 5 \mathrm{in}^{2}$ and maintain the $3.6 \mathrm{kVA}$ rating and amperage indication

- To add a temperature-indicating function and maintain the 16 in. $^{2}$ area, the $3.6 \mathrm{kVA}$ rating, and the amperage indication, and

* Reported by W. R. Wykoff (922). 
- To increase the kVA rating to $22 \mathrm{kVA}$ and maintain the area $>20$ in. ${ }^{2}$, and provide amperage and temperature indications.

The necessary components have been ordered and detailed design is underway. The assembly and evaluation will begin as soon as possible. It is believed that these controllers may have a place on reactor systems, in addition to testing facilities.

\section{Chemistry of Large Sodium Systems*}

R. L. Dillon (AOO)

The objective of the Chemistry of Large Sodium Systems program is to develop methods and equipment for the control of sodium quality in FFTF. This program consists of development tasks for the definition of problems and development of solutions in the areas of in-line instrumentation, cover gas sampling and analysis, sodium purification, and sodium sampling. These tasks will result in prototypes of reactor equipment which are to be developed utilizing the Prototype Applications Loop (PAL) for component testing and later the Sodium Chemical Technology Facility (SCTF) for large scale development and testing.

\section{a. Prototype Applications Loop}

The funding for the fabrication of the PAL has been approved and the initial preparations have begun. The PAL is the first major sodium system to be fabricated under the new Q/A guidelines set forth in BNWL-MA-64; therefore, there will be considerable emphasis on Q/A procedures. The PAL will be fabricated to the Leve1 3 standards specified in BNWL-MA-64. A CPM network describing the design and fabrication tasks and the interaction with Q/A has been prepared.

* Reported by W. R. Wykoff (922). 
b. Project BCE-042 Sodium Chemical Technology Facility

The SCTF has been conceived to provide the basic isothermal forced convection sodium loop required for the study of the chemistry of large sodium systems and for evaluation and development of FFTF and LMFBR purification, analytical, and sampling equipment. The basic loop includes a 1500 gal capacity sodium reservoir and a 2 -in. piping system flowing sodium up to $200 \mathrm{gpm}$ and $1200^{\circ} \mathrm{F}$.

The SCTF is to be funded as a capital equipment project, which is currently in the proposal stage. Rewriting and resubmission of the project proposal has been necessitated by an AEC ruling that the original site, the proposed $190 \mathrm{FA}$ Building, was unacceptable. A feasibility study of the 335 Building showed that SCTF occupancy is compatible with other building functions if the building is modified by providing a pit below and a mezzanine area above floor level to create a 3-level working space.

Accordingly, the SCTF design criteria, preliminary project proposal, and the cost estimate have been rewritten and revised to reflect 335 Building occupancy. A rough draft of the design criteria has been circulated for comments, returned comments incorporated, and the criteria document is being prepared for circulation and approval within BNW.

c. OPERATION OF SODIUM FACILITIES

1. Small Component Evaluation Loop (SCEL)

J. D. Berg (954)

A decision was made to replace the failed pump (reported last month) in this facility with the EM pump that was removed from the Small Heat Transport Loop during upgrading in April. Although the replacement pump (MSA style VI) is smaller than the failed pump, it does have the capacity to supply sodium to 
the remote sampler loop facility which is now connected to the SCEL. Following this installation, the SCEL and remote sampler loop sodium transport lines were preheated and charged with sodium and flow established in the SCEL and through the sampler loop bypass line. An attempt to establish flow through one leg of the sampler was aborted when sodium leaked from one of the mechanical seals in the sample leg. The sampler loop has been frozen off while the sample tube connectors are being modified to prevent leakage. During the interim, the SCEL is operating at $10 \mathrm{gpm}$ and $600^{\circ} \mathrm{F}$ bulk sodium temperature.

2. Small Heat Transfer Loop

J. D. Berg (954)

The 7-pin loose wire wrap fuel cluster was installed in this loop for continuation of the fretting corrosion test. Following system preheat and sodium purification, the loop was increased to test conditions of $1150^{\circ} \mathrm{F}, 19.5 \mathrm{gpm}(\simeq 31 \mathrm{fps})$ by 9-7-69. This test assembly has now accumulated $1530 \mathrm{hr}$ of exposure, of which 530 were accumulated during this report period.

The 7-pin electrically heated simulated fuel assembly, which was removed from this loop on 8-29-69, was cleaned and returned to test sponsors for disassembly and examination. For this cleaning effort, a new procedure was used to minimize the potential of damaging the delicate thermocouples within the test section duct. The new procedure employed hot oil, Dowanol, and water cleaning without submerging the test assembly. This method of cleaning proved to be very satisfactory.

The activities below are being conducted prior to the next 7-pin, electrically heated, simulated fuel assembly test to ensure reliable data: 
a. Thermocouple and RTD Calibration

In-place calibration of the test section inlet and outlet thermocouples and resistance temperature detectors (RTDs) is required. To accomplish this, a dummy test section has been fabricated. This test section contains inlet and outlet thermocouple wells which will house "S" (Platinum, Platinum--10\% Rhodium) type thermocouples for calibration of the in-place RTDs and type "K" (Chrome1--Alumel) thermocouples. The "S" type thermocouples have been calibrated against freeze point standards by the BNW Standards Laboratory.

b. Shielding of Signal Leads

To reduce the noise problem on signals going to the data acquisition system only shielded leads will be used. Shielding of the present leads to the data acquisition system is $70 \%$ complete.

\section{Static Sodium Pots}

J. D. Berg (954)

Pressure transducers in static pots 1,3 , and 4 continued without difficulty throughout this report period. It is significant to report that the transducer in pot 3 has now accumulated $\simeq 6000 \mathrm{hr}$ of exposure. The Taylor pressure transducer in static pot 2 was removed, cleaned, and returned to the test sponsor.

\section{Sodium Purification Loop}

J. D. Berg (954)

This loop has continued operation without interruption with direct reading $\mathrm{O}_{2}$ and carbon probes in service. Loop conditions are being maintained at $600^{\circ} \mathrm{F}$ and $0.5 \mathrm{gpm}$. 
5. Modifications to Fission Product Control Screening Loop* R. L. Dillon (AOO)

A cold trap has been fabricated and installed in the Fission Product Control Screening Loop. The Pressure Piping Completion Record has been approved. The manufacturer supplied the wrong type of variable speed motor for cooling the cold trap. Arrangements have been made with Purchasing to correct this error and the replacement motor will be installed as soon as it arrives.

6. Facilities Additions

a. Project BAP-027 FFTF Sodium Facilities Building K. D. Hayden (954)

Construction work has nearly been completed on the Sodium Facilities Building ( 335 Building). The $100 \mathrm{ft}$ by $60 \mathrm{ft}$ building and the personnel area were accepted from the Fixed Price Contractor on 9-19-69 with exceptions.

J.A. Jones personnel have installed two motor control centers in the building and have completed the outdoor switchgear and transformer installation. The relocation of the Small Components Test Loop from the 314 Building to the 335 Building has been initiated.

b. Project BCP-035 Building Mezzanine Addition

This project is being carried out to provide space for location of sodium development facilities. Completion is expected prior to the end of calendar year 1969.

* Reported by W. R. Wykoff (922). 
c. Project BAP-032 LMFBR Core Segment Development Facility K. D. Hayden (954)

Design effort by Vitro is continuing on the LMFBR Core Segment Development Facility. The architectural and structural drawings are essentially complete. Continued effort is being applied to incorporate appropriate stress analysis into the design of the sodium vessels and piping.

It is intended to proceed on a separate bid package for the pit and steel-lined caisson. This bid award is scheduled to be awarded about the middle of November, 1969.

d. Project BCE-037 Fast Reactor Thermal Engineering Facility K. D. Hayden (954)

The design of the Fast Reactor Thermal Engineering Facility is about $30 \%$ complete. Design Criteria Revisions 1 and 2, providing for substituting an EM or centrifugal free surface pump in the primary loop instead of the excess CANEL pump and for relocating the loop and test section outside Building 3718 , were prepared and all approvals have been received.

BNW Quality Assurance Requirement 4-10 for "Construction Quality System Requirement" and Quality Assurance clauses have been prepared for application by the construction contractor during the FRTEF construction phase.

In compliance with BNWL-MA-64, BNW Manual for Design Construction of Systems and Equipment Containing Liquid Alkali Metal, Paragraph 5.6, Physics and Engineering Division has established a design safety review committee. A preliminary review meeting was held on October $14,1969$. 
BNWL - 1246

e. $\frac{\text { Cover Gas Evaluation Loop (CGEL) }}{\text { R. L. Dillon et al. (AOO) }}$

The Cover Gas Evaluation Loop is an isothermal sodium loop of about 40 gallon capacity for the study of sodium cover gas interactions and the testing of cover gas and sodium analysis instruments.

Construction of the Cover Gas Evaluation Loop has been completed and the system was successfully pressure tested and leak checked. The Pressure Piping Completion Record has been approved. However, extensive modifications have been requested to meet up-dated experimental requirements. The functional requirements are being prepared and detailed design for the modifications will begin shortly after receipt of the functional requirements.

Initial startup of the CGEL is planned for late November.

The first model of an in-line instrument package system is being designed for the CGEL and will contain an oxygen, carbon, and plugging meter. New bypass loops for two oxygen meters, one carbon meter and an oscillating plugging meter, with the necessary temperature and flow controls will be built for the CGEL package.

* Reported by W. R. Wykoff (922). 


\section{CHAPTER VI. CORE DESIGN}

(See Appendix A for List of Author Codes Used in This Report.)

A. CORE MECHANICS CONCEPTUAL DESIGN, DEVELOPMENT, TESTING

1. Reactor Core Hardware Development P1an

J. F. Wett (913)

a. Reactor Hardware Test Program

L. R. Bese1 (913)

The objective of this work is to identify the areas of the current FFTF reactor core design which warrant developmental testing prior to their incorporation into the reactor plant and to prescribe such tests along with the recommended test facilities.

A discussion of the potential problem areas where testing is warranted has been prepared for all core subassemblies. Future plans are to group these problems according to test facility requirements and to identify the test priority which should be followed. Overall test procedures will then be developed for each facility.

b. Mechanical Core Mockup L. R. Bese1 (913)

A mechanical core mockup has been suggested as a component which will be needed for FFTF hardware development. A study has been started to define more precisely the type of mockup needed for each of the components which would be assembled to form the Mechanical Core Mockup. The determinations are being made on the basis of the tests which would be performed with each of the components. The interaction of the tests proposed for the various components is also being examined to arrive at a logical sequence for assembling the complete mockup, since much testing can and should be done during the assembly phase. 
2. Core Support Structure

D. J. Oakley (913)

Design analysis on the core support structure was redirected from a $17-\mathrm{ft}$ internal diameter vessel to a $20-\mathrm{ft}$ internal diameter. The initial drawings show that the core support structure is $20 \mathrm{ft}$ in diameter, and approximately $4-\mathrm{ft}$ thick.

Design criteria are being developed for the design of the core support structure. The limitation of core plate motion is established, since it implies a movement of the control rods with respect to the core. The following limits are established:

\begin{tabular}{|c|c|c|}
\hline Condition & $\begin{array}{l}\text { Reactivity } \\
\text { Limit, } \phi \\
\end{array}$ & $\begin{array}{c}\text { Core Plate } \\
\text { Motion Limit, } \\
\text { in. }\end{array}$ \\
\hline $\begin{array}{l}\text { S1ow Oscillations (frequency } \\
<1 \text { cps) }\end{array}$ & 1 & \pm 0.020 \\
\hline $\begin{array}{l}\text { Operating Transients (e.g., } \\
\text { startup) }\end{array}$ & 5 & \pm 0.100 \\
\hline $\begin{array}{l}\text { Accident Conditions (no } \\
\text { fuel melting) }\end{array}$ & 50 & \pm 1.0 \\
\hline $\begin{array}{l}\text { Shock Wave (e.g., check valve } \\
\text { slam) }\end{array}$ & 50 & \pm 1.0 \\
\hline
\end{tabular}

Stress determination will be based upon this ASME Code, Section 3 properties and intent.

Design drawings of the core support structure have been started, but are not complete. Based upon the structure shown, a steady state deflection of approximately 0.015 in. is calculated.

The sodium erosion tests of the hydraulic balance and fue 1 assembly seat, $T-1 B$ and $T-1 D$, are not in operation. (See also Chapter VB paragraph 3.) Test $T-1 B$ is at LMEC and has been delayed by loop operational difficulties. The test section 
had seal caps on the ends of the headers, which prior to loop installation had to be cut off. Upon removal of the seal caps, metal chips were found inside the headers. A procedure for additional inspection and cleaning the test section has been worked out and is being conducted.

Test T-1D is in fabrication. However, the design of the fuel assembly seat may have to be modified to match the design that is being developed and shown on the core support drawings.

3. Radial Restraint Design and Development

a. Computer Code Development Support

L. R. Bese1 (913)

The object of this effort is to provide experimental data for evaluation of two finite element computer codes for swe11ing and creep analysis of FTR driver fuel ducts. The two codes involved are the AXICRP computer code and the CRASID computer code. The latter one is under development.

The material characterization experiment, involving creep bending of a square bar of stainless steel at a temperature of $1200^{\circ} \mathrm{F}$, is underway. Calibration tests and bend tests to check out and calibrate the instrumentation were completed. Strain gages have been affixed along the length of the bar to monitor possible strain variations with temperature. A minimum test period of $1000 \mathrm{hr}$ is planned.

Scheduled testing of the hexagonal duct (the pure bend creep test) depends on the timely delivery of the required oven and installation of additional electrical power to the test site. 
b. Core Restraint Development

L. R. Bese1 (913)

The core restraint development and test program is to provide experimental data for design input, and development information necessary to demonstrate that the core restraint devices and systems are capable of meeting the design requirements within the constraint of the design and safety criteria. This effort is to include interfacing with such other core components as the instrument tree and IVHM.

As agreed with Westinghouse in a meeting on September 9, the simulated core model is to be constructed to evaluate experimentally kinematic and structural design problems related to core restraint, duct insertion and withdrawal, and preferred fuel management schemes. A project proposal for the simulated core model is being prepared so that detail design and procurement of materials can be initiated. Scope drawings are presently in progress to define the model and associated systems more precisely.

c. Simulated Core Model

G. R. Waymire, W. U. Jackson (811)

Restraint Development. Based on the agreements reached with Westinghouse concerning development testing in support of the radial restraint as noted in last month's report, conceptual drawings of a full core simulator have been completed as supporting information for the Simulated Core Mode1 (SCM). The design utilizes simulated ducts fabricated from tubing with simulated stiffness. The contact pad area will be mocked-up with hexagonal stock attached to the tubes. Loading is afforded by a system of hydraulic jacks at the three loading elevations. Core support will utilize a tubesheet with prototypical seat configuration. Plan and elevation views are shown in Figures 6.A.1 and 6.A.2, respectively. 


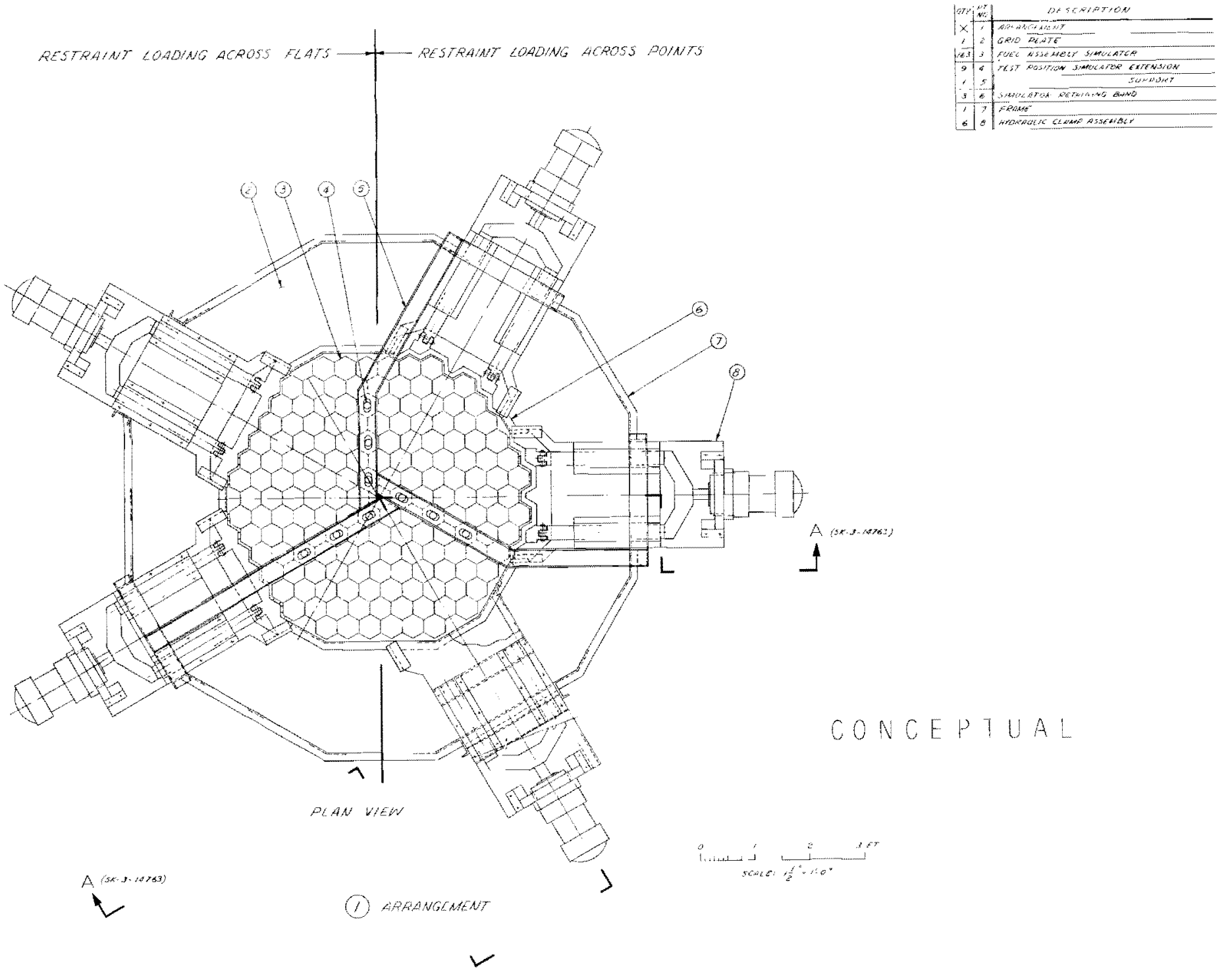

$S K-3-14762$

FIGURE 6.A.1. Simulated Core Model plan 


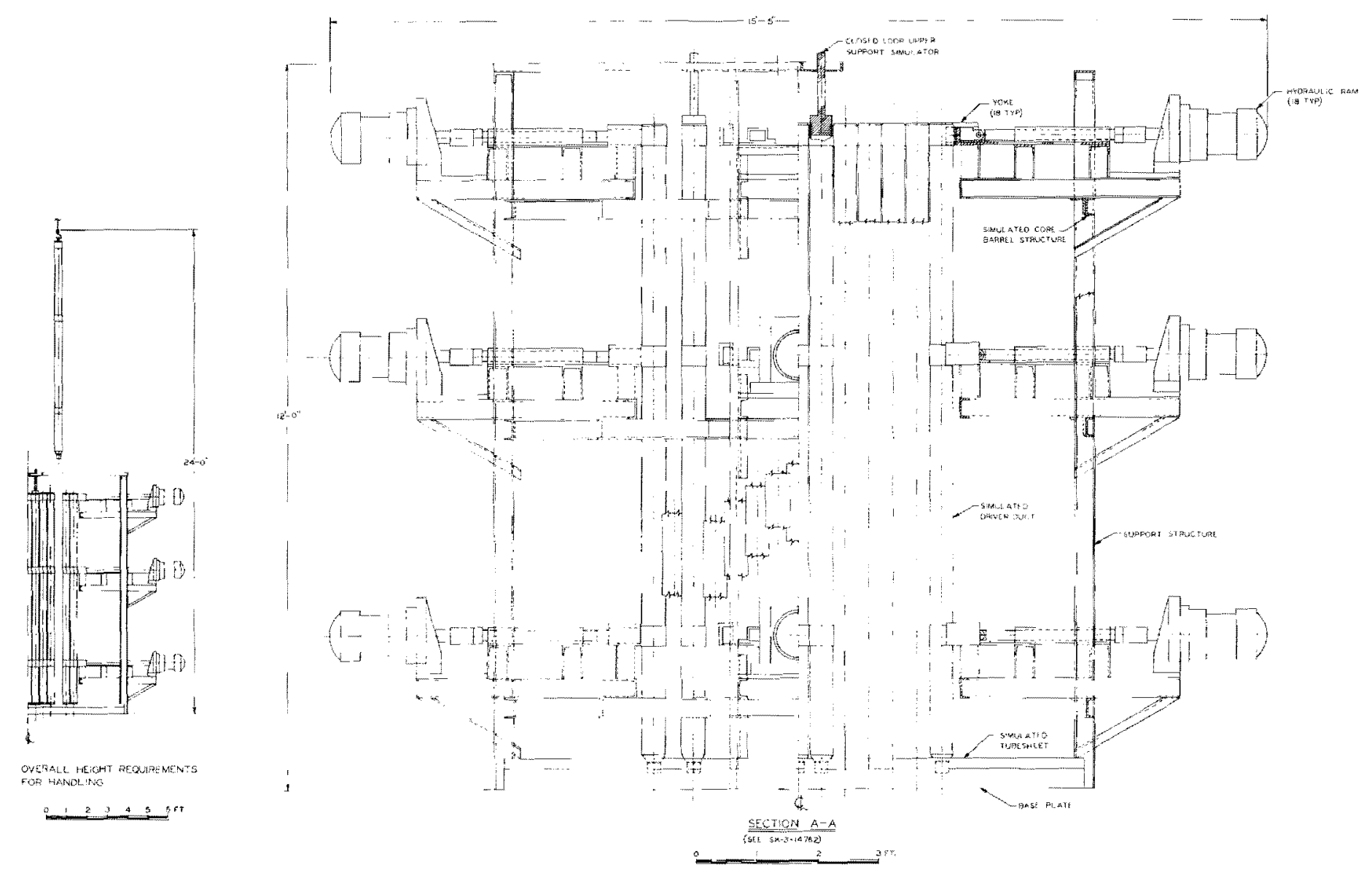

$S K-3-14763$

FIGURE 6.A.2. Simulated Core Model SCM Evaluation 
4. Core Structural Analys is

R. J. Jackson (832)

The Core Structures Study Group has completed its definition of the reactor environment and identification of the major core component design problems facing the RPD. The definition of the reactor environment included detailed maps of the temperatures, fluences, and metal swelling throughout the core. Resultant structural changes caused by metal swelling and thermal distortion were calculated. Ducts, closed loops, and control assemblies lengthening, dilating and bowing, and interactions were predicted by use of elastic theory. A brief summary of the results are presented in Table 6.A.I. The structures report is being prepared.

TABLE 6.A.I. Calculated Results of Thermal Distortions Component Impact of Swelling on Performance

Driver Ducts

- Dilation leading to contact between Rows 1 , 2 , and 3 for Type 304 SS after about 220 days.

- Duct bending is largest in Rows 5 and 6 .

- Duct top deflection during refueling is almost entirely restrained by the reflectors in Rows 7,8 , and 9 .

- Length increase can be accommodated by design changes in the instrument tree.

Control Rods - Large diametral clearances are required between the guide tube and inner duct for adequate control rod life.

Closed Loops - Closed loop dilatation and bending causes contact between it and adjacent ducts at about 320 days in Rows 5 and 6 (approximately 40,000 MWd/tonneM burnup in these rows) using the preferred CW Type 316 SS.

- A crushing interference fit from differential swelling is predicted between the flow tube and the flow tube line. 
BNWL- 1246

\section{Creep Code Development \\ W. H. Sutherland (COO)*}

A general finite element analysis procedure has been defined which will permit the creep analysis of FFTF fuel as sembly ducts, or any other statically indeterminate beam with arbitrary cross-section. This formulation is sufficiently general to include all of the RPD code specifications (WARD-FRA-25) with the exception of the plasticity capability. Furthermore, the incremental procedure employed for creep analysis has the potential to be generalized to include plasticity.

The creep formulation and documentation has been completed. Generalization of the incremental procedure to include plasticity is projected completion early in the fourth quarter of the fiscal year.

6. Core Concept

a. Reactor Core CSDD

G. R. Waymire (811)

Formal comments received from RDT concerning the Reactor Core CSDD have been reviewed. As a result of this review, most of the requested changes are being incorporated through the BNW approval chain. Several comments concerned the nonbaseline sections of the document and will be changed by Westinghouse at a later date.

* Reported by L. M. Finch (810) 
b. Concept Evaluation

D. Marinos, G. R. Waymire, and A. J. Anthony (811)

The Westinghouse concept evaluation report is complete and has been transmitted internally for comments. The report compares the reference concept and the Westinghouse concept, with variations on both. Specific comparisons include

- Cost, and

- Availability.

Potential problem areas are also identified.

B. CORE PROCESS TECHNOLOGY

1. Hydraulic Core Mockup - Studies

H. Leigh (954), and D. L. Ballard, P. M. Jackson,

J. Spalek, G. W. Riedeman, L. R. Sweetin (COO)

a. Dispersion of Gas Bubbles

The one-third size hydraulic model of the FFTF piped inlet arrangement was operated to study the effects of large gas volumes entering the inlet chamber. Colored movies and black and white still photographs were taken to record observations on the efficiency of the plenum and basket assembly in dispersing gas bubbles. A slug of air (approximately 630 in. ${ }^{3}$ ) was dumped through one downcomer, with the inlet elbows at $221 / 2$ degrees from axial position. This volume was well dispersed in the inlet plenum. The gas bubbles were broken up (diameter sized between $1 / 8$ and $1 / 4$ in.) as they passed into the basket and were uniformly distributed to all core flow channels. A second test condition involved bleeding a small but unmeasured air flow into one downcomer. Again, bubbles were quite uniformly distributed over the core.

b. U1trasonic Measurements of Relative Air Content

The first on-line ultrasonic measurements of relative air content in the outlet model outlet pipe have been performed. 
These measurements were done before on-line void fraction calibration data were available. However, the initial on-1ine measurements yielded the following important information:

- The success of the ultrasonic measurements of air content (in bubble form) in the 10-in. pipe of the outlet mode1, at flow rates up to $3600 \mathrm{gpm}$, confirmed experimentally the applicability of the ultrasonic pulse-transmission technique for on-line gas entrainment measurements.

- Hydraulically induced mechanical vibrations in the pipe holding the transducers have no adverse effect on the ultrasonic measurements .

Observed changes in the velocity of sound in water induced by changes in water temperature, also have no effect on the gas content measurements.

- Also, under the normal operating conditions with sma11 and gradual temperature changes, the different thermal expansions of the Lucite and stainless steel transducer mounts induce no adverse results. However, in a system with fast, large temperature changes, thermal expansion would misalign the transducers so that remounting and recalibrating would be necessary.

c. Scale Model of Hydraulic Core Mockup

H. Leigh (954)

The contract for the HCM Scale Model with Atkins and Merrill, Inc., is in place and the initial meeting with them has been held. The contract for the model was based on a onehalf scale model of a 17 -ft diameter vessel, and the piping system and vessel support design are essentially complete with the required pipe on order. Because of schedule and cost constraints, the decision has been made to retain the model size of $8.5 \mathrm{ft}$ diameter after the recent FTR concept diameter change from 17 to $20 \mathrm{ft}$, with the result that the model scale will be 0.425 to 1.0 rather than 0.5 to 1 . The model designer 
will proceed on this basis after BNW receives sufficient information from Westinghouse to proceed productively on the mode1 design.

Overall design for the HCM facility is $80 \%$ complete and construction is $60 \%$ complete.

2. Sodium Flow Testing

a. Mark I Sodium Flow Test

T. J. Bennett (913)

The rough draft of the final report for the Mark I sodium flow test has been written. The purpose of this test was to evaluate the effect of sodium flow through a candidate (dispersed core) fuel bundle for the FFTF driver fuel. This bundle consisted of 217 pins, each 0.25 in. in diameter, and wrapped with $0.030-i n$. wire wrap on a 12-in. pitch. Both pins and cladding were made with Type 304 SS.

b. Mark I I Sodium Flow Test

(1) Engineering Test Plan [T. J. Bennett (913)]. The Engineering Test Plan for the Mark II sodium flow test has been approved by BNW management and is being sent to Argonne National Laboratory for concurrence. The Mark II bundle simulates the driver fuel for the vertical core concept. The test plan calls for the 217-pin bundle $(0.230-i n$. diameter pins wrapped on a 12 -in. pitch with $0.056-$ in. wire wrap) to be tested for $9000 \mathrm{hr}$ at 1100 to $1150{ }^{\circ} \mathrm{F}$ with a sodium flow rate of $525 \mathrm{gpm}$. Cladding and wrap are constructed of Type $316 \mathrm{SS}$.

(2) Subassembly Fabrication [D. E. Blahnik, R. B. Baker, and R. L. Myers (732)]. Development of a welding procedure for lower end cap closure welds was completed with satisfactory results for the modified lower end cap design. The operating procedure for welding the lower end cap was written. Approximate 1 y $75 \%$ of the lower end caps were welded. 
An operating procedure for loading the pins was written and loading started. One hundred and fifty pins were loaded through the upper reflector, including the 40 pins to be fully characterized. Five pins were rejected because of the difficulty (pellet jamming) of using the specified small pelletto-cladding gap.

A decision was made to expand the duct $0.054-i n$. beyond the theoretically tight bundle size. Using actual pin dimensions, the theoretically tight bundle measures 4.303-in. across flats. Therefore, the duct is being expanded to an inside flat to flat measurement of 4.357 in. Measurements of the wire and cladding $O D$ were made to verify the cross flats bundle size. Duct nosepiece sections must be modified slightly for welding.

The lower spacing grid was redesigned to increase its strength for the projected test conditions. The new design requires fabrication of a new set of grid plates.

The design of the upper grid and upper end cap was not resolved.

$$
\text { c. Loose Wire Wrap } 7 \text {-Pin Assembly }
$$

After a pump failure in the SCTL loop (Sma11 Components Test Loop-BNW), the 7-pin bundle containing loose and broken wire wraps (three with $0.020-$ in. 1ooseness, three with $0.030-$ in. looseness, and one broken wire wrap at the inlet end of the assembly) was transferred to the Heat Transfer Loop No. 1 . To date this assembly has been exposed to about $1600 \mathrm{hr}$ of $1150^{\circ} \mathrm{F}$ sodium. The sodium flow velocity through this assembly is 31 feet per second. This 7 -pin bundle will be removed from the HTL-1 loop after $2000 \mathrm{hr}$ of testing, inspected, and reinstalled in the SCTL 1oop. 
3. Bypass Flow Cooling of Driver Assemblies

D. C. Kolesar (832)

A modified version of the COBRA II code was used to predict the extent of driver duct cooling induced by bypass flow. The bypass flow is through the gaps between assemblies. The ducts were modeled by a slit approximation. (1) The power distribution was characteristic of assemblies located at the outer periphery of the core. The hydrodynamic effects of the wire spacers were not considered. The core flow rate and therefore core thermal balance was allowed to change slightly as the bypass flow was increased.

It was found that increasing the bypass flow rate may cause the duct temperatures to be reduced significantly. However, the temperature gradient through the wall is insensitive to this flow.

4. Fue 1 Performance Analysis

a. Dimensional Analyses of Typical FTR Fuel Pins

R. D. Leggett (750), E. O. Ballard (750),

D. C. Bullington (750), F. E. Bard (750), and

K. R. Merckx (AOO)

An analysis of the expected deformations in 0.230 in. OD FTR fuel pins was completed using the most recent equations for cladding swelling for cold worked Type 316 SS, the latest estimates of pin powers and burnups in the FTR and the computer codes, SINTR, EXPAND, DEFORM, PECT-I and CYGRO. It was assumed that a $91 \%$ dense mixed oxide fuel pellet, 0.194 in. in diameter operated with an initial (cold) 6-mil diametral fuel-cladding gap at the following reference power levels:

1. C. L. Wheeler, EFTE Monthly Informal Technical Progress Report, BNWL-990, Battelle-Northwest, Richland, Washington, January 1969. 
- $4.8 \mathrm{~kW} / \mathrm{ft}$ (minimum)

- $8.7 \mathrm{~kW} / \mathrm{ft}$ (average)

- $12.2 \mathrm{~kW} / \mathrm{ft}$ (maximum)

- $14.6 \mathrm{~kW} / \mathrm{ft}$ (20\% overpower)

An arbitrary incubation period of $4 \%$ BU was assumed before the fuel and cladding interacted and, the fuel was assumed to swell as a function of burnup rate and temperature. Maximum diameter increases of about $5.4 \%$ and $3.7 \%$ were predicted for the $20 \%$ overpower pin and low power pin, respectively, at $80,000 \mathrm{MWd} /$ tonneM.

b. Hybrid Computer Simulation

R. D. Leggett (750), R. L. Fish (722),

and C. R. Cole (MOO)

Equations describing fission gas release, pressure buildup, 2-zone and 3-zone sintering and thermal flux radial power profiles were programmed into the hybrid computer and are in the final stages of debugging.

c. Additions to the SINTR Computer Code

E. O. Ballard (750)

SINTR (a simple fuel restructuring, one dimensional, steady-state heat transfer computer code) was revised to include calculations such as fission gas generation as a function of axial position, cladding fluence, and swelling.

C. IRRADIATION TEST FACILITIES

1. Closed Loops [4 MW Closed Loop Ce11 Size Assessment (AI)] M. A. Voge1 (924)

Atomics International under the Technical Direction of Westinghouse completed an assessment of the cell size required for a 4-MW special purpose 10op. It was established that the Primary Heat Transport System cell should be $14 \times 18 \times 42 \mathrm{ft}$ deep and the purification cell $14 \times 14 \times 12 \mathrm{ft}$ deep. The 
bases for this study were the requirements outlined in BNWL-500, Vol. 61, Conceptual System Design Description for the Closed Loops, except that the components were derated from 6 to $4 \mathrm{MW}_{t}$. The above cell dimensions were determined by three principal considerations:

- Number and size of components

- Space to accommodate bends to relieve pipe stresses

- Space to provide both completely remote and contact maintenance.

The study also recommended that a shield wall between the heat transport and purification cell is not required from the consideration of maintenance.

The above information was transmitted to Bechtel to serve as design bases for the closed loop structures within containment.

2. 2-MW Simple Unitized Modular Closed Loop (AI)

M. A. Vogel (924)

BNW provided testing requirements to Westinghouse to serve as a basis for developing the 2-MW loop concept. These are given in Table 6.A.II. Atomics International under the Technical Direction of Westinghouse completed an interim concept definition for a 2-MW simple unitized modular closed loop.

The loop concept definition is not yet complete. Simplification was attained by deleting some components, by relying on contact maintenance and by redefining components on the basis of the 2 -MW heat dissipation requirement. The loop concept was unitized to the extent that the entire primary heat transport system package can be preassembled and installed as a unit. Modularization has been provided to permit remote removal of any one of five primary system modules from the cell in the event of major, nonremovable contamination. 


\section{TABLE 6.A.II. 2-MW Closed Loop Testing Requirements}

Test Conditions

in Primary system

Maximum $\mathrm{Na}$ temperature leaving test

Maximum heat generation (test + structura1)

Maximum $\mathrm{Na}$ hot leg temperature

Maximum $\mathrm{Na}$ cold leg temperature

Maximum $\mathrm{Na}$ flow rate

Minimum $\mathrm{Na}$ flow rate

Maximum $\Delta \mathrm{T}$ (hot leg versus cold leg)

Maximum test $\Delta \mathrm{P}$

Minimum cold leg temperature
Value or Criteria $1400^{\circ} \mathrm{F}$

Achieved by internal bypassing and reducing to heat generation of test compatible with maximum flow capability

$2 \mathrm{MW}$

$1200^{\circ} \mathrm{F}$

$1150^{\circ} \mathrm{F}$

$200{ }^{\circ} \mathrm{F} \Delta \mathrm{T}$ minimum

at $2 \mathrm{MW}(\sim 290 \mathrm{gpm})$

$10 \%$ of maximum

To define control range

$400{ }^{\circ} \mathrm{F}$

$100 \mathrm{psi}$ at $200^{\circ} \mathrm{F}$ $\Delta \mathrm{T}(290 \mathrm{gpm})$

To define design pump head higher head will be available at lower flow

$600{ }^{\circ} \mathrm{F}$ at $2 \mathrm{MW}$ Lower temperature permitted at less than $(145 \mathrm{gpm}) \quad 2 \mathrm{MW}$ 
3. Prototype Loop Test Planning

M. A. Vogel (924), and J. C. Moore (COO)

Test plans were prepared for the Prototype Closed Loop. These plans included objective, scope, justification, method and expected results for the following type of tests:

- Preoperational testing

- Steady state testing

- Transient testing

- Remote maintenance testing

- Accelerated life tests

- Decontamination testing

These test plans were based on the former 6-MW 100 p concept. Plans will be revised to reflect the $2-M W 100 p$ concept after concept definition is completed.

4. Technical Program Management

BNW-Westinghouse negotiations relative to scope of work and schedule for performing Prototype Closed Loop design under Contract BDR-619 are continuing.

BNW representatives participated in a Westinghouse review of Atomics International work on closed loop rescoping studies.

5. Closed Loop Mechanica1 Seal Closure Program

R. Kolowith (914), and M. R. Kreiter, E. F. Antal,

S. K. Meyers, J. V. Thompson ( $\mathrm{COO})$

The objectives of this task are to; (a) provide experimental test data verifying the principles of operation of a creep compensating connector assembly, (b) provide experimental test data for each of six specified seal concepts being considered for FFTF closed 1oop nozzle closure application, (c) establish a reference clamping device design and seal(s) 
for subsequent reliability testing, and (d) provide technical guidance and evaluation in the development of a commercially available instrumentation connector.

\section{a. Test on NDA 4-Point Seal}

The first seal performance data has been recorded on this program. Proof pressure and leakage tests have been completed on one NDA 4-point seal. This seal concept was developed by Nuclear Development Associates and described in their report, Design Development Tests of Some Components for the $10 \mathrm{MW}$ SDR, (Doc. No. NDA-84-21, May 25, 1969). Three seals with a cross section similar to that described by NDA, but 1 arger in diameter were fabricated from Armco Ingot Iron. The load versus deflection curve at $18,0001 \mathrm{~b}$ loading indicated that the sea 1 seated properly and that the spool was securely latched in the nozzle. The seal contained 375 psig helium with no structural deformation evident after the test.

A room temperature leak rate test was conducted. A leakage rate of $3.2 \times 10^{-4} \mathrm{~atm} \mathrm{~cm}^{3} / \mathrm{sec}$ was measured at a pressure differential of 250 psi across the seal. There was no indication of clamp failure at any time during the test. Visual examination of the connector assembly after disassembly revealed no indications of connector failure.

A NDA report gives leak rates of $2 \times 10^{-6} \mathrm{~atm} \mathrm{~cm}^{3} / \mathrm{sec}$ and $2 \times 10^{-7}$ atm $\mathrm{cm}^{3} / \mathrm{sec}$ at $15 \mathrm{psi}$ differential for two different seals. Extrapolation of $B N W$ data gives a leak rate of $4 \times 10^{-7} \mathrm{~atm} \mathrm{~cm}^{3} / \mathrm{sec}$ at that pressure.

b. Pressure Transient Test

Available funding forces indefinite suspension of preparation for the pressure transient test. 
6. Closed Loop Tube Hardware Weld Closure Studies

J. W. Kolb (914), L. J. Rousseau (COO)

The design for the proof of principle prototype remote welder has been completed. The procurement of critical items for the assembly is $90 \%$ complete. Fabrication of the structural portion of the head assembly is in progress. Final modifications to the environmental test chamber have been completed. The chamber will be relocated to the BNW weld laboratory where proof of principle testing will be performed.

The automatic weld power supply and programmer has passed acceptance testing and is being prepared for weld testing.

7. Closed Loop Tube Remote Cutter

R. F. Gilmore (914)

An evaluation of development test results and reliability study has been completed for the selection of the proof of principle cutter test machine. The Side Mill Cutter remote machine has been chosen for fabrication, while development work on the Multiple Tooth tool concept will continue as a ready backup.

The design for the proof-of-principle machine is $65 \% \mathrm{com}-$ plete. The procurement of critical long lead components is $80 \%$ complete. Demonstration tests of the remote cutter are scheduled for December 1969.

8. Closed Loop Me1tdown

R. E. Keyes (812)

An analysis was made of the feasibility of retaining the melt of a $4-\mathrm{MW}$ test in the bottom of the in-reactor test section. The results were included in section 17 of the PSAR. The results revealed that for an 0.7-in. thick tantalum cup at the bottom of the test section, and an external flow of $\sim 20 \mathrm{gpm}$, melt through did not occur. 
BNWL - 1246

D. OTHER CORE DESIGN

1. Advanced Core Studies

L. M. Finch, G. R. Waymire, and A. J. Anthony (810)

In conjunction with the core analysis section, an advanced core study has been completed. The report appraises the likely candidates for the second generation core of the FTR and defines the reactor components that are replaced during a second generation core installation.

Although a large number of potential fuels were examined as possible candidates, the prime incentives for advanced cores and state of the art ruled out all but three candidates for this initial study. Primary incentives included:

- Improved neutron flux

- Improved thermal performance

- Improved economics

- Improved availability.

Table 6.D.I. outlines the advanced core characteristics, while Table 6.D.II assesses the required component changeouts needed for each candidate fuel.

The characteristics of the full performance oxide and carbide cores are delineated in Tables 6.D.III and 6.D.IV, respectively. The fuel assemblies and tentative core maps for these concepts are shown conceptually in Figures 6.D.1 and 6.D.2.

The changes in the internal component dimensions which promulgate the changeouts noted in Table 6.D.II are shown in Figure 6.D.3. 
IABLE 6.D.I.

ADVANCED FFTF CORE CHARACTERISTICS

\begin{tabular}{|c|c|c|c|c|}
\hline $\begin{array}{l}\text { CANDIDATE } \\
\text { ADVANCED FUEL } \\
\end{array}$ & INCENTIVE FOR USE & $\begin{array}{l}\text { CONTRIBUTING CHARACTERISTIC } \\
\text { CORE OR FUEL }\end{array}$ & ADVANCED DESIGN FEATURE & $\begin{array}{l}\text { ADVANTAGE TO } \\
\text { LMFBR PROGRAM }\end{array}$ \\
\hline \multirow[t]{6}{*}{$\begin{array}{l}\text { MIXED OXIDE } \\
(U-P) O_{2}\end{array}$} & $\begin{array}{l}\text { GREATER NEUTRON FUX } \\
\text { FOR TESTS } \\
{\left[0.9 \times 10^{16} \text { NEUTRON }\right.} \\
\left.\mathrm{Cm}^{2}-S E C\right] .\end{array}$ & $\begin{array}{l}\text { - HIGHER LINEAR POWER RATING-FUEL PIN } \\
\text { - HIGHER CORE POWER DENSITY }\end{array}$ & $\begin{array}{l}\text { - DECREASE LENGTH OF FUEL REGIOY } \\
\text { - DECREASE LATTICE SIZE } \\
\text { - DECREASE NUMBER OF FUELASSEMBLIES } \\
\text { - INCREASED COOLANT VELOCITY } \\
\text { - HIGH TEMPERATURE FUEL CLAD MATERIAL } \\
\text { - IMPROVED FUEL CONDUCIIVITY } \\
\text { - REDUCED OVERPONER FACTOR } \\
\text { - IMPROVED CORE INSTRUMENTATION }\end{array}$ & $\begin{array}{l}\text { - IMPROVED BREEDING RATIO } \\
\text { - HIGH POWER DENSITY }\end{array}$ \\
\hline & SAFETY & $\begin{array}{l}\text { - ASSURED CORE SUPPORT INTEGRITY } \\
\text { - IMPROVED CORE INSTRUMENTATION }\end{array}$ & $\begin{array}{l}\text { - SMA LLER FUEL ASSEMBLIES } \\
\text { - IMPROVED CORE SUPPORT } \\
\text { - INCREASED SHIELDING FOR CORE SUPPORT } \\
\text { STRUCTURE } \\
\text { - IMPROVED INSTRUMENT 'TREE" DESIGN } \\
\text { - RADIATION RESISTANT MATERIALS } \\
\text { - IMPROVED CONTROL ARRANGEMENT }\end{array}$ & IMPROVED SAFETY \\
\hline & TEST ACCESSIBILLTY & REDUCED HEAD AREA CONGESTION & $\begin{array}{l}\text { - IMPROVED TEST LOOP ARRANGEMENT } \\
\text { - REDUCED IEST LOOP SIZE }\end{array}$ & IMPROVED TEST DATA \\
\hline & FUEL ECONOMY & IMPROVED FUEL BURNUP & $\begin{array}{l}\text { - RADIATION DAMAGE RES I STANT CLAD AND } \\
\text { STRUCTURE } \\
\text { - REDUCED TEMP. AND STRAIN GRADIENTS - } \\
\text { REDUCED METAL SWELLING } \\
\text { - INCREASE LENGTH ABOVE CORE FOR EXTENDED } \\
\text { FISSION GAS PLENA }\end{array}$ & IMPROVED FUEL CYCLE COST \\
\hline & PLANT AVAILAB ILITY & $\begin{array}{l}\text { - IMPROVED FUEL LIFE } \\
\text { - HIGH INIEGRITY CORE COMPONENTS } \\
\text { - IMPROVED CONTROL MATERIAL LIFE }\end{array}$ & $\begin{array}{l}\text { - SEE ABOVE } \\
\text { - INCREASED NUMBER OF REP LACEABIE } \\
\text { COMPONENIS TO INCUIDE CORE SUPPORT } \\
\text { AND RESTRA INT }\end{array}$ & $\begin{array}{l}\text { - PLANT AVAILABILITY } \\
\text { - ACCELERATED ACCUMULATION } \\
\text { OF LMFBR DATA }\end{array}$ \\
\hline & LMFBR PROTOTYPICALITY & $\begin{array}{l}\text { EVOLUT IONARY IMPROVEMENT OVER INITIAL } \\
\text { CORE FOR FFFF }\end{array}$ & HIGHER POWER DENSITY FUEL & $\begin{array}{l}\text { PROTOTYPE OR } \\
\text { DEMONSTRATION UNIT FUEL }\end{array}$ \\
\hline \multirow[t]{7}{*}{$\begin{array}{l}\text { MIXED CARB IDE } \\
\text { (U-P)C }\end{array}$} & $\begin{array}{l}\text { GREATER NEUTRON FLUX } \\
\text { FOR TESTS } \\
{\left[1.25 \times 10^{16} \text { NEUTRONi }\right.} \\
\left.\mathrm{cm}^{2}-\mathrm{SEC}\right]\end{array}$ & $\begin{array}{l}\text { - HIGHER LINEAR POWER RATING-FUEL PIN } \\
\text { - HIGHER CORE PONER DENSITY } \\
\text { - IMPROVED FUEL THERMAL CONDUCTIVITY }\end{array}$ & $\begin{array}{l}\text { - DECREASE LENGTH OF FUEL REGION } \\
\text { - DECREASE LATIICE SIZE } \\
\text { - DECREASE NUMBER OF FUELASSEMBLIES } \\
\text { - INCREASE COOLANT VELOCITY } \\
\text { - HIGH TEMPERATURE FUEL CLAD MATERIAL } \\
\text { - IMPROVED FUEL CONDUCTIVITY } \\
\text { - IMMPROVED CORE INSTRUMENTATION } \\
\text { - REDUCED IN-CORE CONTROL } \\
\text { - REDUCED COOLANT PRESSURE LOSS } \\
\text { - VENTED FISSION GAS FUEL PIN DESIGN }\end{array}$ & $\begin{array}{l}\text { - IMPROVED BREED ING RATIO } \\
\text { - HIGH POWER DENSITY }\end{array}$ \\
\hline & $\begin{array}{l}\text { HIGHER COOLANI } \\
\text { OUILET TEMPERATURE } \\
\text { (1100 OF) }\end{array}$ & & $\begin{array}{l}\text { - IMPROVED HIGH TEMPERATURE MATER IAL } \\
\text { - IMPROVED CORE RESTRA INT } \\
\text { - IMPROVED INSTRUMENTATION } \\
\end{array}$ & $\begin{array}{l}\text { HIGHER THERMODYNAMIC } \\
\text { EFFICIENCY }\end{array}$ \\
\hline & SAFETY & $\begin{array}{l}\text { - ASSURED CORE SUPPORT INTEGRITY } \\
\text { - IMPROVED CORE INSTRUMENTATION }\end{array}$ & $\begin{array}{l}\text { - } \text { SMALLER FUELASSEMBLIES } \\
\text { - IMPROVED CORE SUPPORT } \\
\text { - INCREASED SHIELDING FOR CORE SUPPORT } \\
\text { STRUCTURE } \\
\text { - IMPROVED INSTRUMENT"TREE" DESIGN } \\
\text { - RADIATION RESISTANT MATERIALS } \\
\text { - IMPROVED CONTROL ARRANGEMENT } \\
\end{array}$ & IMPROVED SAFETY \\
\hline & TEST ACCESS IBILITY & REDUCED HEAD AREA CONGESTION & $\begin{array}{l}\text { - REDU CED IN-CORE CONTROL } \\
\text { - IMPROVED TEST LOOP ARRANGEMENT } \\
\text { - REDUCED TEST LOOP SIZE }\end{array}$ & IMPROVED IEST DATA \\
\hline & FUEL ECONOMY & IMPROVED FUEL BURNUP & $\begin{array}{l}\text { - RADIAIION DAMAGE RESISTANT CLAD AND } \\
\text { STRUCTURE } \\
\text { - REDUCED TEMPERATURE AND STRAIN } \\
\text { GRADIENTS - REDUCED METAL SWELLING }\end{array}$ & IMPROVED FUEL CYCLF COST \\
\hline & PIANT AVA IIAB ILITY & $\begin{array}{l}\text { - IMPROVED FUEL LIFE } \\
\text { - HIGH INTEGRITY CORE COMPONENTS } \\
\text { - IMPROVED CONTROL MATERIAL LIFE }\end{array}$ & $\begin{array}{l}\text { - SEE ABOVE } \\
\text { - INCREA SED NUMBER OF REPLACEABLE } \\
\text { - COMPONENTS TO INCLUDE CORE SUPPORT } \\
\text { AND RESTRAINT }\end{array}$ & $\begin{array}{l}\text { - FUEL LIFE } \\
\text { - LOWER COST FOR FULL CYCLE } \\
\text { - PLANT AVAILABILITY } \\
\text { - ACCELERATED ACCUMULATION } \\
\text { OF LMFBR DATA } \\
\end{array}$ \\
\hline & LMFBR PROTOTYPICALITY & ALTERNATE FUEL CHOICE FOR LMFBR & HIGHER POWER DENSITY FUEL & $\begin{array}{l}\text { PROTOTYPE OR } \\
\text { DEMONSTRATION LNII FUEL }\end{array}$ \\
\hline \multirow[t]{2}{*}{ LMFBR PROTOTYPE } & $\begin{array}{l}\text { FIND SOLUTION TO FUEL OR } \\
\text { CORE PROBLEM }\end{array}$ & $\begin{array}{l}\text { EXAMPLES: } \\
\text { - PONER INSTABILITY } \\
\text { - VIBRATION } \\
\text { - COMPONENI DISTORIION } \\
\text { - INSTRUMENI RESPONSE } \\
\end{array}$ & & \\
\hline & $\begin{array}{l}\text { DEMONSTRATE SATIS- } \\
\text { FACTORY SOLUTON TO } \\
\text { PROTOTYPE PROBLEM }\end{array}$ & $\begin{array}{l}\text { EXAMPLES: } \\
\text { - TRANSIENT PONER RESPONSE } \\
\text { - MELTDOWN (SAFETY) } \\
\text { - COOLANT BOILING (SAFETY) } \\
\text { - THERMAL DISTORTION }\end{array}$ & & \\
\hline
\end{tabular}


IABLE 6.D.11.

REACTOR CHANGES REQUIRED FOR ADVANCED CORES

\begin{tabular}{|c|c|c|c|c|c|c|c|c|c|c|c|c|}
\hline \multirow{3}{*}{$\begin{array}{c}\text { ADVANCED } \\
\text { DEडIGN FEATURES }\end{array}$} & \multirow{2}{*}{\multicolumn{2}{|c|}{$\begin{array}{c}\text { TYPICAL } \\
\text { FOR ADVANCED CORE } \\
\end{array}$}} & \multicolumn{10}{|c|}{ REQUIRED CHANGE OF ORIGINAL REACTOR COMPONENTS } \\
\hline & & & \multirow[b]{2}{*}{ FUEL } & \multirow{2}{*}{$\begin{array}{l}\text { TEST } \\
\text { LOOPS }\end{array}$} & \multirow{2}{*}{$\begin{array}{l}\text { CONTROL } \\
\text { RODS }\end{array}$} & \multirow[b]{2}{*}{ REFLECTORS } & \multirow[b]{2}{*}{ SHIELDS } & \multirow{2}{*}{$\begin{array}{c}\text { CORE } \\
\text { SUPPORT }\end{array}$} & \multirow{2}{*}{$\begin{array}{c}\text { CORE } \\
\text { BARREL } \\
\text { \& RESTRAINT }\end{array}$} & \multirow{2}{*}{$\begin{array}{l}\text { INSTRUMENT } \\
\text { TREE \& PLUG }\end{array}$} & \multirow{2}{*}{$\begin{array}{c}\text { IVHM } \\
\text { AND PLUG }\end{array}$} & \multirow{2}{*}{$\begin{array}{l}\text { REACTOR } \\
\text { COVER }\end{array}$} \\
\hline & OXIDE & CARB IDE & & & & & & & & & & \\
\hline 1. CHANGE CORE LENGTH & $x$ & $x$ & $x$ & $x$ & $x$ & $x$ & $x$ & - & $x$ & $x$ & $x$ & - \\
\hline BELOW FUEL REGION & INCREASE & INCREASE & & & & & & & & & & \\
\hline FUEL REGION & DECREASE & DECREASE & & & & & & & & & & \\
\hline ABOVE FUEL REGION & INCREASE & DECREASE & & & & & & & & & & \\
\hline 2. CHANGE CORE LATTICE & $x$ & $x$ & $x$ & $x$ & $x$ & $x$ & $\mathrm{x}$ & $x$ & $x$ & $x$ & - & $x$ \\
\hline SIZE & DECREASE & DECREASE & & & & & & & & & & \\
\hline NUMBER & DECREASE & DECREASE & & & & & & & & & & \\
\hline 3. CHANGE TEST LOOPS & $x$ & $\mathrm{x}$ & - & $x$ & - & - & - & $x$ & - & $\mathrm{x}$ & - & $\mathrm{x}$ \\
\hline ARRANGEMENT & $x$ & $x$ & & & & & & & & & & \\
\hline NUMBER & DECREASE & DECREASE & & & & & & & & & & \\
\hline SIZE & DECREASE & DECREASE & & & & & & & & & & \\
\hline KIND & $x$ & $x$ & & & & & & & & & & \\
\hline 4. CHANGE NUCLEAR CONTROL & $x$ & $x$ & - & - & $x$ & $x$ & - & $x$ & $x$ & $x$ & - & $x$ \\
\hline ARRANGEMENT & $x$ & $x$ & & & & & & & & & & \\
\hline NO. IN-CORE & DECREASE & DECREASE & & & & & & & & & & \\
\hline NO. EX-CORE & & & & & & & & & & & & \\
\hline SIZE & DECREASE & DECREASE & & & & & & & & & & \\
\hline KIND & $x$ & $x$ & & & & & & & & & & \\
\hline 5. CHANGE CORE INSTR. & $x$ & $x$ & - & - & - & - & - & - & - & $x$ & - & - \\
\hline FLOWMETER & $x$ & $x$ & & & & & & & & & & \\
\hline TEMPERATURE & $x$ & $x$ & & & & & & & & & & \\
\hline FEDAL & $x$ & $x$ & & & & & & & & & & \\
\hline $\begin{array}{l}\text { 6. CHANGE CORE SUPPORT } \\
\text { TECHNIQUE }\end{array}$ & $x$ & $x$ & - & - & - & $x$ & - & $x$ & $x$ & $x$ & - & $x$ \\
\hline RADIAL & $x$ & $x$ & & & & & & & & & & \\
\hline $4 X \mid A L$ & $x$ & $\mathrm{x}$ & & & & & & & & & & \\
\hline MECHANISM & $x$ & $x$ & & & & & & & & & & \\
\hline
\end{tabular}


TABLE 6. D. III

FULL PERFORMANCE OXIDE FUELED CORE

\section{PARAMETER}

FUEL TYPE

BOND (FUEL/CLADDING)

FISSION GAS DISPOSAL

TOTAL NUMBER LATTICE POSITIONS

CLOSED LOOP LOCATIONS

OPEN TESTS (CONTACT INSTRUMENTED)

OPEN TESTS (PROXIMITY INSTRUMENTED)

SAFETY RODS

IN-CORE CONTROL RODS

PERIPHERAL CONTROL RODS

DRIVERS

CORE VOLUME

EFFECTIVE NUMBER OF DRIVERS (COUNTING OPEN LOOPS AT $75 \%$ )

BULK OUTLET TEMPERATURE

HTS OPERATING POWER LEVEL

PEAK FLUX

PEAK ASSEMBLY POWER RATING

CORE OUTLET TEMPERATURE

ASSEMBLY BULK COOLANT $\triangle T$, ORIFICED

NUMBER FUEL PINS PER ASSEMB LY

FUEL PIN OD

SPACER WIRE DIAMETER

COOLANT VELOCITY IN HOT DUCT, ORIFICED

SUBASSEMBLY $\triangle P$, INCLUDING ORIFICE

FLOW DUCT INSIDE DIMENSION

FLOW DUCT OUTSIDE DIMENSION

FUEL LENGTH

PIN LENGTH

PEAK LINEAR POWER INCLUDING 1.14 ENGINEERING FACTOR FUEL PIN ID

PEAK HEAT FLUX

PEAK CLAD TEMPERATURE (ORIFICED)

PEAK FUEL \& TEMPERATURE

CLADDING

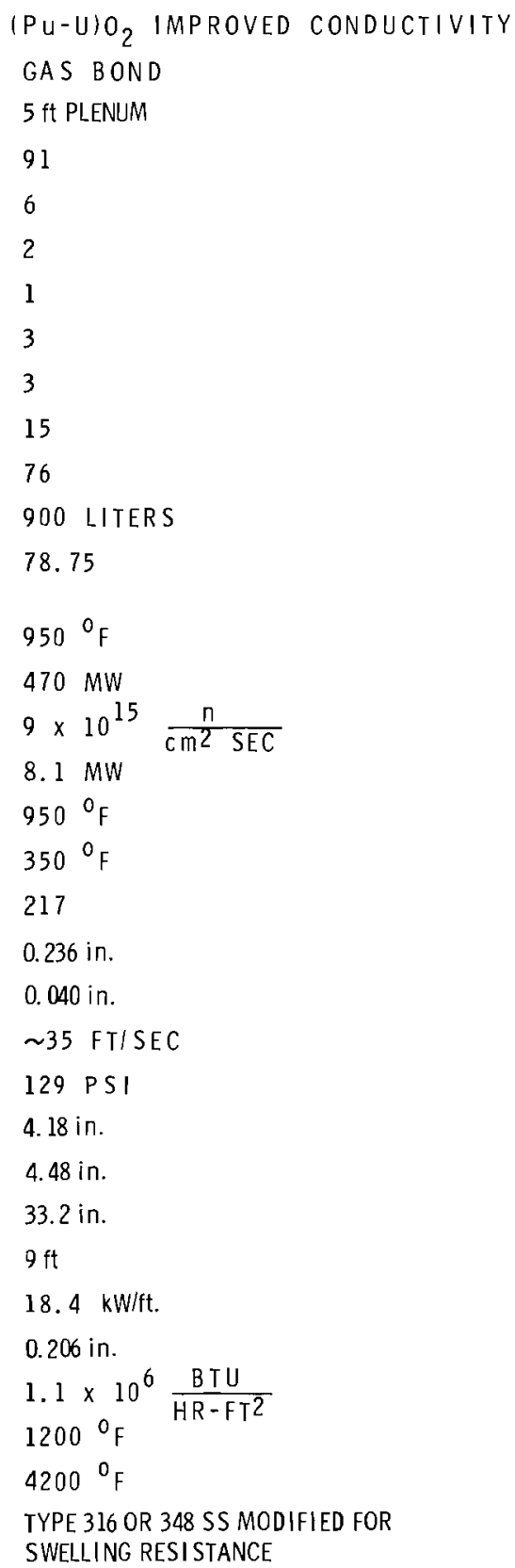

78.75 $950^{\circ} \mathrm{F}$

$470 \mathrm{MW}$

$9 \times 10^{15} \frac{\pi}{\mathrm{cm}^{2} \mathrm{SEC}}$

8.1 MW

$950^{\circ} \mathrm{F}$

$350^{\circ} \mathrm{F}$

217

$0.236 \mathrm{in}$.

$0.040 \mathrm{in}$.

$\sim 35 \mathrm{FT} / \mathrm{SEC}$

129 PSI

4. 18 in.

$4.48 \mathrm{in}$.

$33.2 \mathrm{in.}$

$9 \mathrm{ft}$

$18.4 \mathrm{~kW} / \mathrm{ft}$.

0.206 in.

$1.1 \times 10^{6} \frac{\mathrm{BTU}}{\mathrm{HR}-\mathrm{FT}^{2}}$

$1200^{\circ} \mathrm{F}$

$4200^{\circ} \mathrm{F}$

TYPE 316 OR 348 SS MODIFIED FOR SWELLING RESISTANCE 
TABLE 6. D. IV.

FULL PERFORMANCE CARBIDE FUELED CORE

\section{PARAMETER}

FUEL TYPE

BOND (FUEL/CLADDING)

FISSION GAS DISPOSAL

TOTAL NUMBER LATTICE POSITIONS

CLOSED LOOP LOCATIONS

OPEN TESTS (CONTACT INSTRUMENTED)

OPEN TESTS (PROXIMITY INSTRUMENTED)

SAFETY RODS

PERIPHERAL CONTROL RODS

DRIVERS

CORE VOLUME

EFFECTIVE NUMBER OF DRIVERS (COUNTING OPEN LOOPS AT $75 \%$ )

HTS OPERATING POWER LEVEL

PEAK FLUX

PEAK ASSEMBLY POWER RATING

CORE OUTLET TEMPERATURE

ASSEMBLY BULK COOLANT $\triangle T$, ORIFICED

ASSEMBLY BULK COOLANT $\triangle T$, UNORIFICED

NUMBER FUEL PINS PER ASSEMBLY

FUEL PIN OD

SPACER WIRE DIAMETER

COOLANT VELOCITY IN HOT DUCT, ORIFICED

COOLANT VELOCITY IN HOT DUCT, UNORIFICED

ASSEMBLY $\triangle P$, INC. ORIFICED, UNORIFICED

FLOW DUCT INSIDE DIMENSION

FLOW DUCT OUTSIDE DIMENSION

FUEL LENGTH

PIN LENGTH (VENTED PLENUM)

OVERALL ASSEMBLY LENGTH

PEAK LINEAR POWER 191\% DEPOSITION, 1.14 ENGINEERING FACTORI AT OPERATING POWER

FUEL PIN ID

PEAK HEAT FLUX

PEAK CLADDING TEMPERATURE:

1100 BULK OUTLET (ORIFICED)

1100 BULK OUTLET (UNORIFICED)

PEAK FUEL \& TEMPERATURE:

1100 BULK OUTLET (ORIFICED)

1100 BULK OUTLET (UNORIFICED)
$(P U-U) C$

GAS

VENTED (DIVING BELL)

61

5

1

3

3

12

49

590 LITERS

51

$470 \mathrm{MW}$

$1.25 \times 10^{16} \frac{\mathrm{n}}{\mathrm{cm}^{2} \mathrm{SEC}}$

$\sim 11 \mathrm{MW}$

$1100^{\circ} \mathrm{F}$

$350^{\circ} \mathrm{F}$

$460^{\circ} \mathrm{F}$

169

0.262 in.

0.046 in.

$48 \mathrm{FT} / \mathrm{SEC}$

$37 \mathrm{FT} / \mathrm{SEC}$

110 PSI

80 PSI

4. $120 \mathrm{in}$.

$4.500 \mathrm{in}$.

$32 \mathrm{in.}$

52 in.

$10 \mathrm{ft} 10 \mathrm{in}$.

$37 \mathrm{~kW} / \mathrm{ft}$

$0.228 \mathrm{in}$.

$2.2 \times 10^{6} \frac{B T U}{H R-F T^{2}}$

$\sim 1300{ }^{\circ} \mathrm{F}$

$\sim 1450^{\circ} \mathrm{F}$

$3270^{\circ} \mathrm{F}$

$3360^{\circ} \mathrm{F}$

6.24 


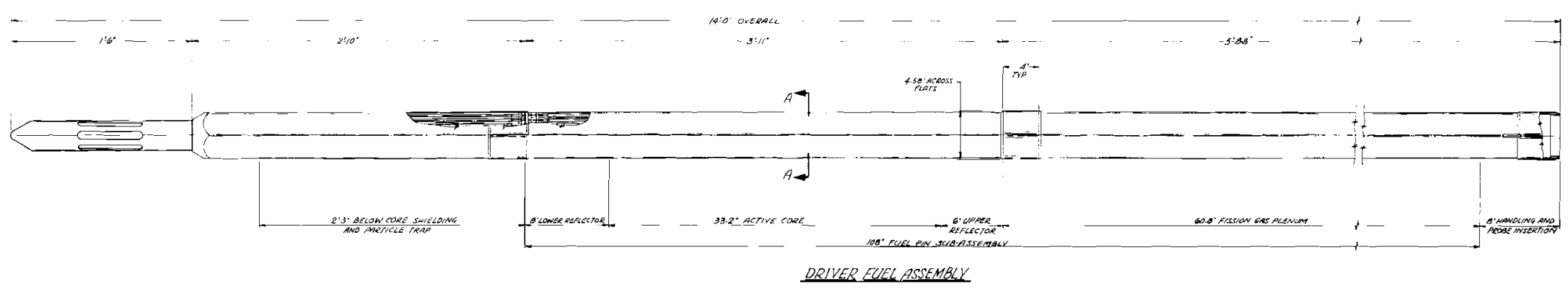

in
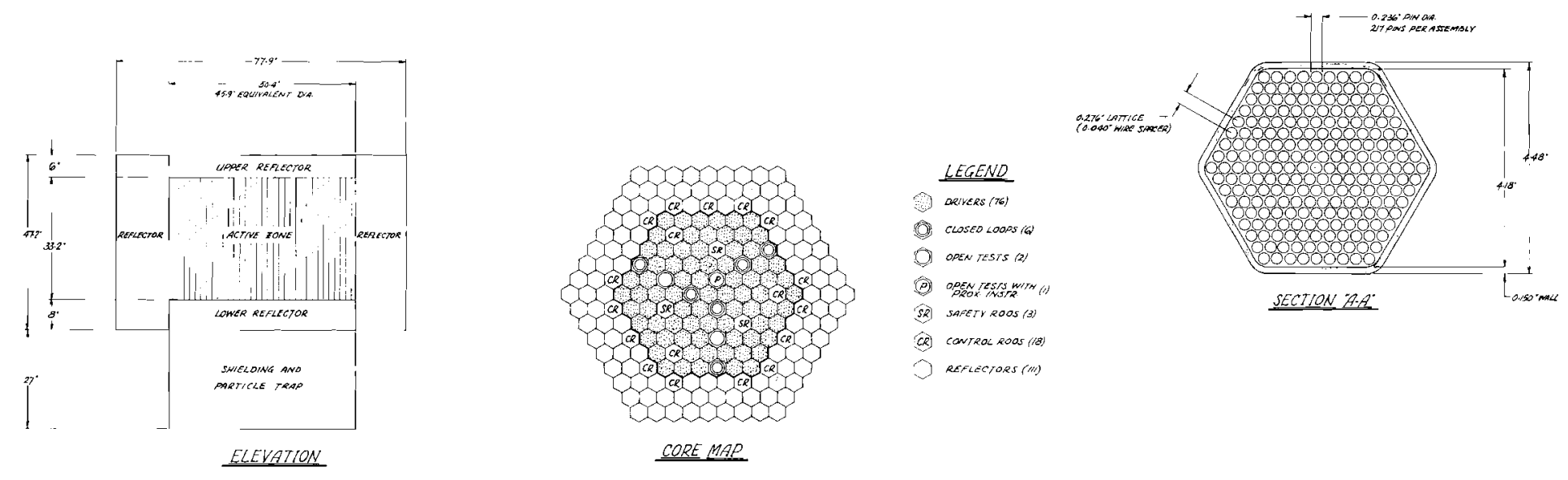


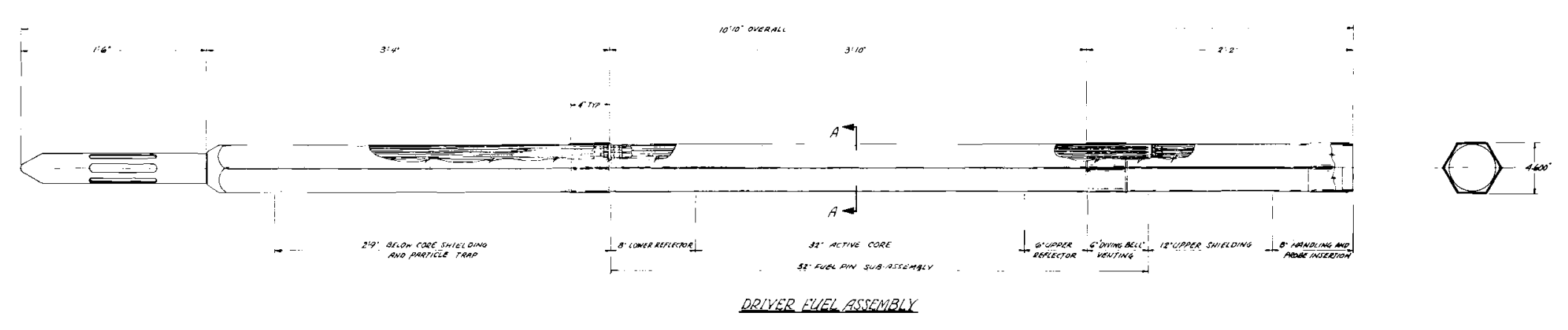

a
a
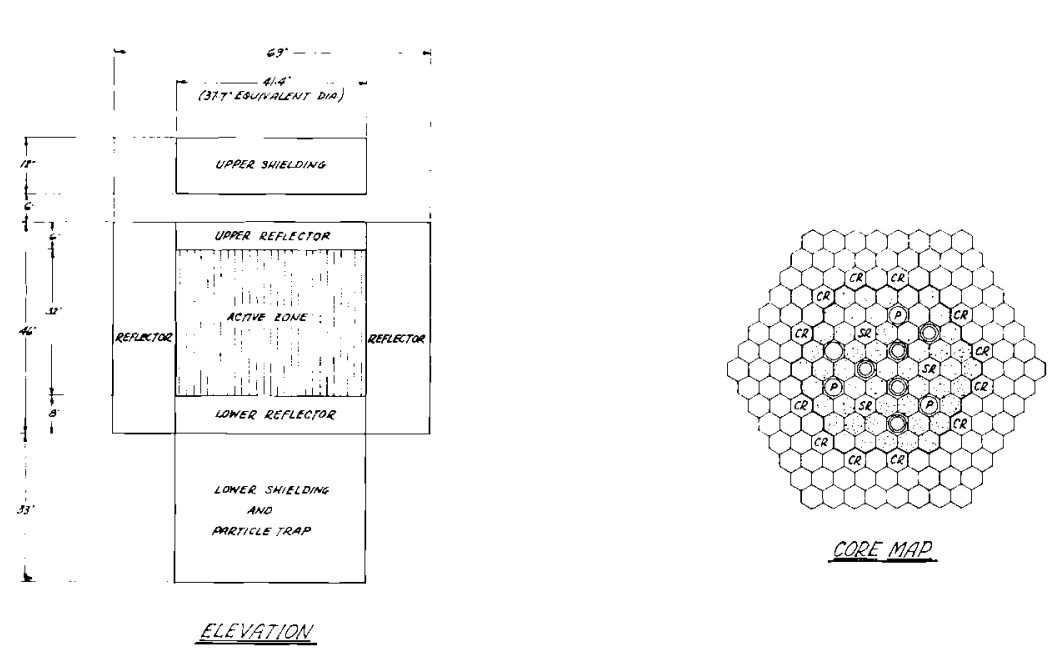

LEGEND

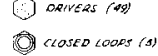

0 open IESTS "⿻

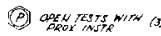

[Sol sagtivecos (i)

(Ge) cantroce gods (1/2)

CORE MAD

(1) effectoes (\%)

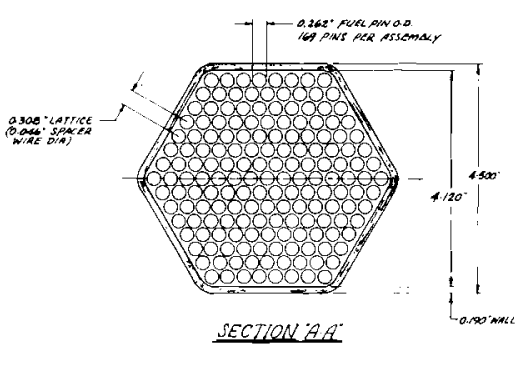

$S K-3-14751$

FIGURE 6.D.2. Advanced Core Study Carbide Fuel (Gas Bonded, Vented) 

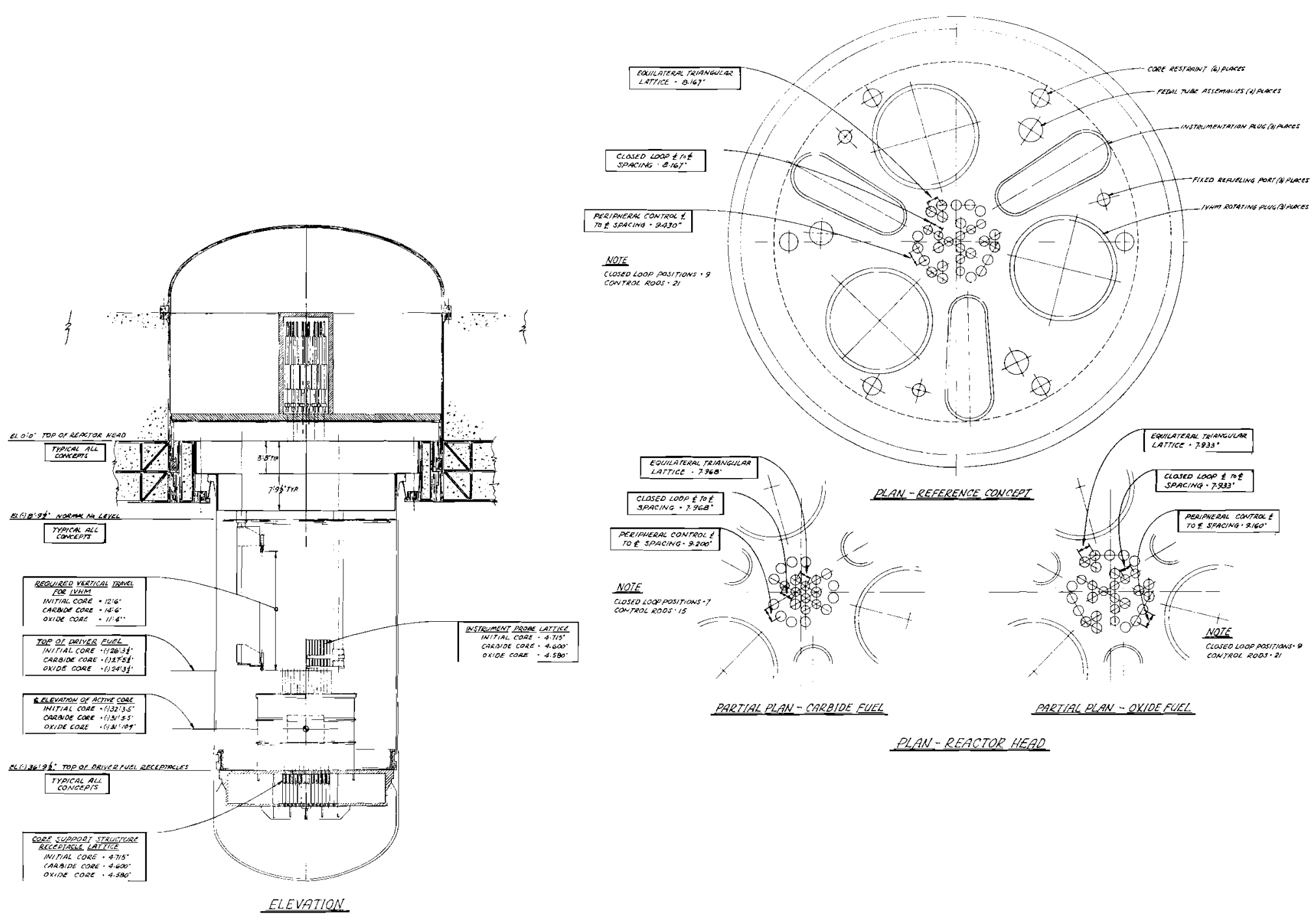

$S K-3-14752$

FIGURE 6.D.3. Advanced Core Study Required Reactor Changes 


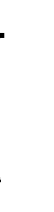


BNWL -1246

CHAPTER VII. FUELS AND MATERIALS EVALUATION

(See Appendix A for List of Author Codes Used in This Report.)

\section{A. FUELS AND MATERIALS EVALUATION \\ 1. BNW-1 Series Capsule Irradiations}

a. Status

J. E. Hanson (750)

The status of the BNW-1 capsule series is summarized in Table 7.A.1. Two capsules continue their irradiation toward a goa 1 exposure of $100,000 \mathrm{MWd} /$ tonneM.

b. Compilation of Fabrication and Irradiation Histories J. W. Weber and D. W. Dragnich (750)

Axial power distributions were calculated based on burnup analyses and gross, or ${ }^{95} \mathrm{Zr} /{ }^{95} \mathrm{Nb}$ axial gamma scans for BNW-1-4, 1-6, 1-9 and 1-11. These data are being compared to axial power distributions derived from thermocouple data. This comparison showed that the power derived from the thermocouple data is from 5 to $20 \%$ less than the power calculated from burnup data. Work is being continued in the reduction of thermocouple data and axial gamma scans to obtain a better correlation.

\section{c. Gamma Scanning of Irradiated Pins}

J. W. Weber (750), D. E. Christensen (COO), and

C. F. Beyer (COO)

Axial gamma scans for gross activity and for ${ }^{95} \mathrm{Zr} /{ }^{95} \mathrm{Nb}$ have shown several activity peaks on BNW-1-1, 1-2, 1-3 and 1-5. Spectra data collected along the length of the fuel pins, including several directly on the activity peaks, are being analyzed with a computer program GSSLRN (Gaussian - Learn) to determine the major gamma-emitting isotopes present. 
TABLE 7.A.I. Summary Status of Irradiation Experiments Conducted Under Task FP-6

Issue Date: $10 / 8 / 69$

\begin{tabular}{|c|c|c|c|c|c|c|c|c|c|}
\hline \multirow[b]{2}{*}{$\begin{array}{c}\text { Test } \\
\text { Designation }\end{array}$} & \multirow[b]{2}{*}{$\begin{array}{c}\text { Description (1) } \\
\text { Fue1 } \\
\text { Form } \\
\end{array}$} & \multirow[b]{2}{*}{$\underline{0} / \mathrm{M}$} & \multirow[b]{2}{*}{ Facility } & \multirow[b]{2}{*}{$\begin{array}{c}\text { Goal } \\
\text { Exposure } \\
\text { MWd/tonneM } \\
\end{array}$} & \multicolumn{5}{|c|}{ Status } \\
\hline & & & & & $\begin{array}{r}\text { Ac } \\
\text { Exp } \\
\text { MWd / }\end{array}$ & $\begin{array}{l}\text { tual } \\
\text { osure } \\
\text { tonneM }\end{array}$ & $\begin{array}{r}\text { Disch } \\
\text { Dat } \\
\end{array}$ & erge & Status \\
\hline BNW 1-1 & Solid & 1.93 & MTR & 100,000 & (Est) & 120,000 & & $2-69$ & Being Exam, at BNW \\
\hline BNW $1-2$ & Solid & 1.93 & ETR & 50,000 & (Est) & 70,000 & & $2-69$ & Being Exam. at BNW \\
\hline BNW $1-3$ & Solid & 1.96 & MTR & 100,000 & (Est) & 150,000 & & $2-69$ & Being Exam. at BNW \\
\hline BNW $1-4$ & Solid & 1.96 & MTR & 50,000 & & 71,000 & & $6-68$ & Exam. Completed at BNW \\
\hline BNW 1- 5 & Solid & 2.00 & MTR & 100,000 & $(E s t)$ & 160,000 & & $2-69$ & Being Exam. at BNW \\
\hline BNW $1-6$ & Solid & 2.00 & MTR & 50,000 & & 75,200 & & $10-68$ & Exam. Completed at BNW \\
\hline BNW $1-7$ & Annular & 1.93 & MTR & 50,000 & & $<1,000$ & & & Lead Tube Failed. Exam. at BNW \\
\hline BNW $1-8$ & Annular & 1.93 & MTR & 100,000 & & 29,000 & & $1-68$ & Failed. Exam. at BNW \\
\hline BNW $1-9$ & Annular & 1.96 & MTR & 50,000 & & 81,800 & & $6-68$ & Exam. Completed at LASL \\
\hline BNW $1-10$ & Annular & 1.96 & ETR & 100,000 & (Est) & 86,000 & (Est) & $2-70$ & $\begin{array}{l}\text { Discharged } 2-69 \text { for Interim } \\
\text { Exam. Recharged } 5 / 69\end{array}$ \\
\hline BNW $1-11$ & Annular & 2.00 & MTR & 50,000 & & 87,400 & & $8-68$ & Exam. Completed at LASL \\
\hline BNW $1-12$ & Annular & 2.00 & ETR & 100,000 & $(E s t)$ & 91,000 & (Est) & $2-70$ & $\begin{array}{l}\text { Discharged } 2-69 \text { for Interim } \\
\text { Exam. Recharged } 5 / 69\end{array}$ \\
\hline
\end{tabular}

1. $\quad$ Fue $\underline{2}$

$25 \% \mathrm{PuO}_{2}-75 \%$ UO

Pelzets 0.212 in. $O D(0.052$ in. ID for annuzar pezzets)

Smeared density - $87.5 \%$ TD

Pellet density - solid pelzet $93 \%$ TD, annular pellet $95 \%$ TD

cradding

$O D-0.250 \mathrm{in}$.

Wall thickness - 0.016 in.

Type 304 SS 
Analysis of the BNW-1-1 spectra data by the computer program indicates that the fission product ruthenium is the major contributor to the activity peaks except for one peak at the top of the fuel column which is produced by cesium.

These analyses are being continued.

d. Postirradiation Examination of Fuel Pins J.W. Weber (750), D. E. Christensen (COO), and C. F. Beyer (COO)

BNW-1-1, 1-2, 1-3 and 1-5 were drilled in the plenum sections for measurement of total plenum gas. Samples of this gas were analyzed for composition. Results of the gas measurements and analyses are shown in Table 7.A.II. Calculated fractional fission gas releases are included. Calculation of the theoretically generated fission gas is based on the estimated burnups. There is reason to believe that the estimated burnup of BNW-1-3 is in error in that it is too high. Accurate burnup measurements will be obtained by chemical analysis.
2. BNW Series Fue1 Pins
P. K. McDanie1 (700)
On October 2, 1969 subassemb1y X-018B containing BNW Pin No. BNW B-40 was loaded into position $4 E 2$ of EBR-II reactor grid. This pin contained specimens to evaluate the effects of metallurgical variables on irradiation induced swelling. The estimated discharge data for BNW Pin No. BNW B-40 is October, 1970 .

The four BNW Pins (35, 36, 37 and 38) from subassembly X-067 were disassembled. The specimens are being tested. Flux monitors are at the counting laboratory at Idaho Nuclear Corporation waiting to be counted. 
TABLE 7.A.II. Measurement and Analysis of Fission Gas from $B N W-1-1,1-2,1-3$ and 1-5

\begin{tabular}{|c|c|c|c|c|c|c|c|}
\hline BNW & $\begin{array}{l}\text { Volume of } \\
\text { Plenum Gas } \\
\text { Collected } \\
\text { (ml-STP) } \\
\end{array}$ & $\begin{array}{l}\text { Ana } 1 y \\
\text { \% Xe } \\
\end{array}$ & $\begin{array}{l}\text { sis } \\
\% \mathrm{Kr} \\
\end{array}$ & $\begin{array}{c}\text { Volume of } \\
\text { Fission Gas } \\
\text { Collected } \\
\text { (ml-STP) } \\
\end{array}$ & $\begin{array}{c}\text { Burnup } \\
(\text { est.) } \\
\text { Mwd/tonnem } \\
\end{array}$ & $\begin{array}{c}\text { Volume of } \\
\text { Fission Gas } \\
\text { Theoretically } \\
\text { Generated } \\
\end{array}$ & $\begin{array}{l}\quad \frac{0}{0} \text { of } \\
\text { Fission Gas } \\
\text { Released }\end{array}$ \\
\hline $1-1$ & 184 & 91.18 & 5.28 & 177.5 & 120,000 & 241 & 73.6 \\
\hline $1-2$ & 138 & 90.60 & 5.25 & 132.3 & 70,000 & 142 & 93.0 \\
\hline $1-3$ & 166 & 90.80 & 5.43 & 159.7 & 150,000 & 316 & 50.5 \\
\hline $1-5$ & 208 & 91.34 & 5.12 & 200.6 & 160,000 & 326 & 63.0 \\
\hline
\end{tabular}

3. PNL-1 Series Fue 1 Pins
a. Mechanical Testing
R. L. Fish (722)

The PNL-1 series pins were irradiated in the EBR-II reactor to a peak burnup of approximately $9000 \mathrm{MWd} / \mathrm{tonne.} \mathrm{These}$ pins were clad with annealed Type 304 SS (E-1ot).

As reported earlier, the burst pressures on specimens taken from the upper portion of PNL 1-3 and 1-6 fue 1 pins were much less than that of the controls, plenum, or sections taken from the lower portion of the same pins. The corresponding ductility was also reduced greatly for the upper sections. The reduced strength and ductility was the result of severe intergranular attack by some constituent of the irradiated fue 1 activated by the applied stress.

\section{b. Shielded Electron Microprobe Examination}

E. D. Jenson (AOO)

Efforts to identify the corrosive agent causing the failure by using a shielded electron microprobe have produced inconclusive results. 
A section of fuel pin PNL $1-6-F$ was re-examined in the shielded electron microprobe. The section was prepared using a hydrogenated terephenyl liquid phase with a Freon rinse between each grinding and polishing step.

In an area of cladding-fuel interface the elements $U, P u$, $\mathrm{Cs}, \mathrm{I}, \mathrm{Ba}$, and $\mathrm{Te}$ were found in a layer adhering to the cladding. cladding elements were found as metallic deposits in the fuel matrix and along the walls of a large crack. The composition of the particles in the crack is plotted against distance from the cladding in Figure 7.A.1. Chromium is seen to decrease, while nickel increases with distance from the cladding. Iron is shown as two plots, both decreasing with distance from the cladding. (The two separate segments probably are caused by the electron beam penetrating the smaller particles.)

To eliminate beam penetration effects, the ratio of iron to nicke1, and also of chromium to nicke1, were obtained as shown in Figure 7.A.2; both plots are fitted reasonably we 11 by a straight line. These plots can be interpreted as indicating a decrease in the rate of deposition of iron and chromium with distance from the cladding (increasing temperature) and an increase in the rate of nickel deposition with increasing temperature (distance). Other deposits, not in visible cracks, were found and their composition and distance from cladding is given in Table 7.A.III.

4. PNL-59 Series Fue 1 Pins

G. E. Culley (750)

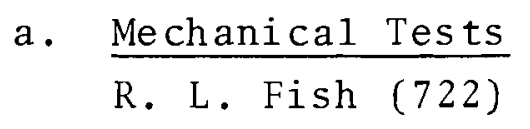

The PNL-59 series fue 1 pins were irradiated in the GETR thermal reactor to a peak burnup of approximately 69,000 MWd per tonne. The pins were clad with annealed Type 304 SS 

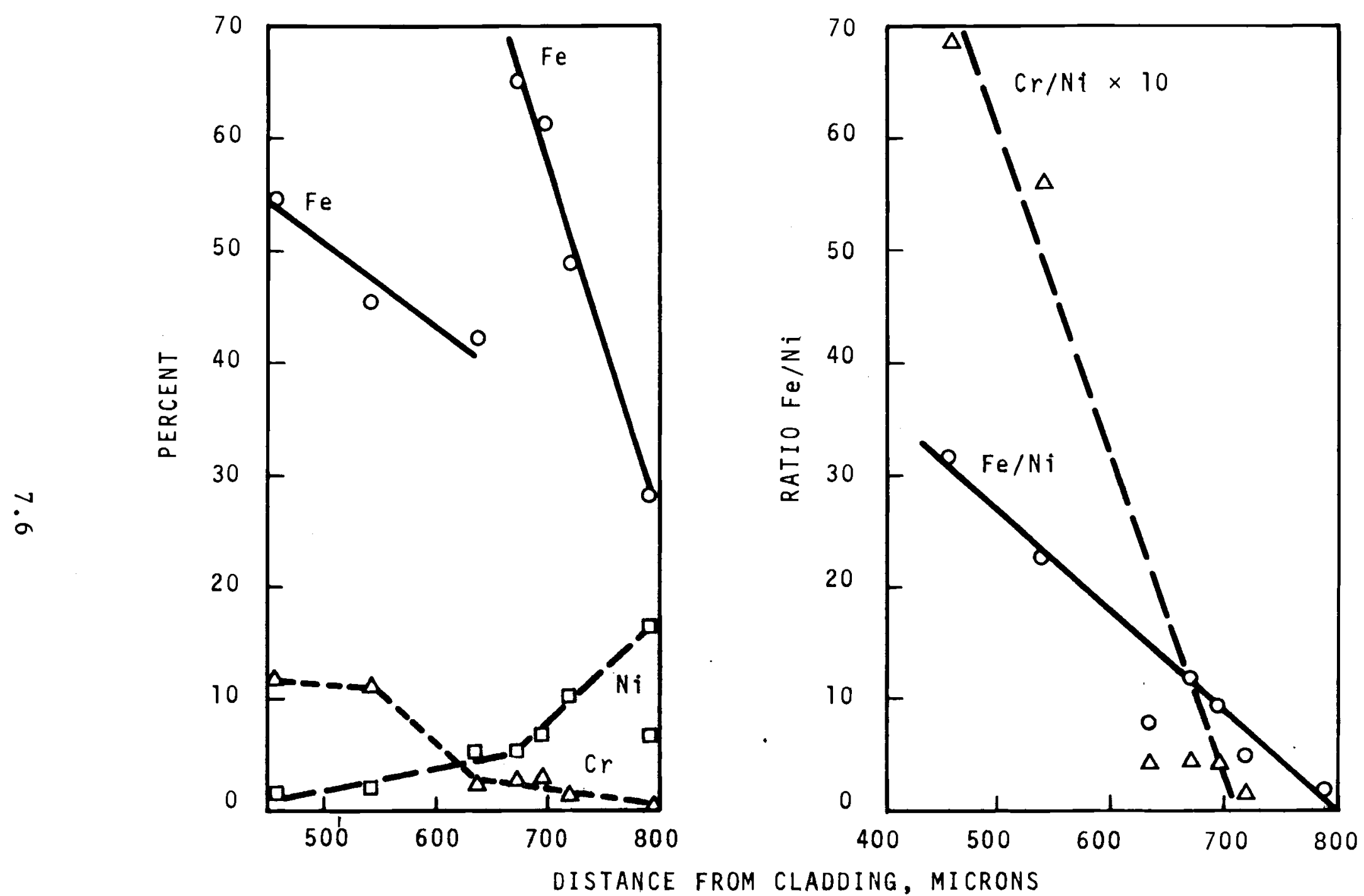

- FIGURE 7.A.1. Iron, Nickel, and

Chromium Composition of Deposits in Fuel Crack Versus Distance

FIGURE 7.A.2. Iron-to-Nickel and Chromium-to-Nickel Ratios in Deposits in from Cladding Fuel Crack Versus Distance from Cladding 
TABLE 7.A.III. Iron, Nickel, and Chromium Content of Metallic Deposits Not in Cracks in Fuel Pin PNL 1-6-F.

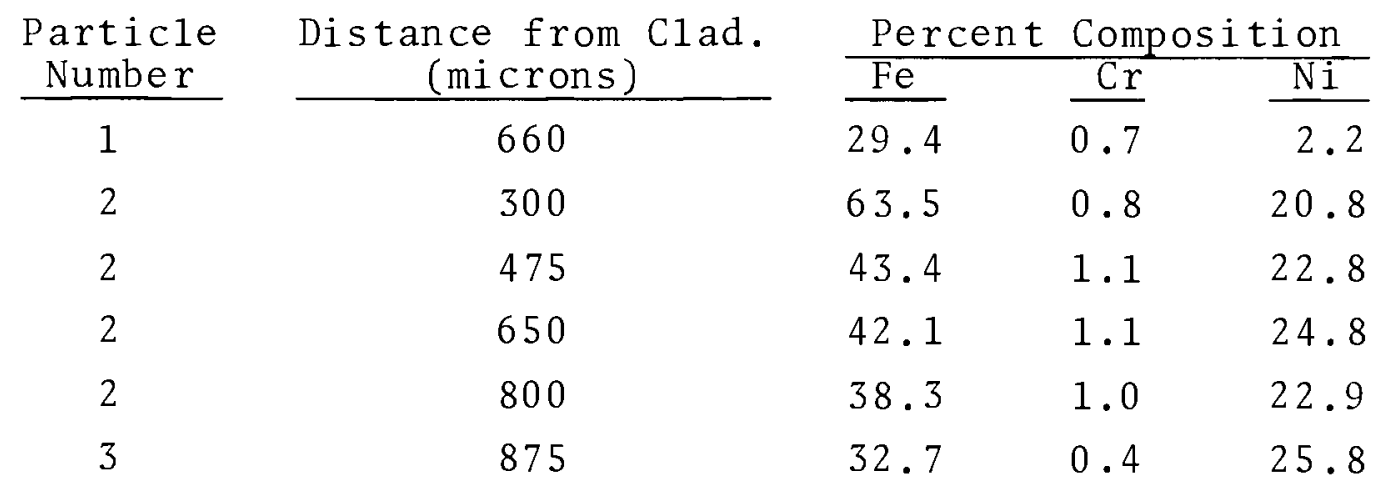

$(\mathrm{F}-10 \mathrm{t})$. The total peak fluence was $2.8 \times 10^{20} \mathrm{n} / \mathrm{cm}^{2}$, (E $>0.18 \mathrm{MeV})$. Temperature and fluence values for two specimens burst tested from the PNL 59-7 pin at 900 and $1450{ }^{\circ} \mathrm{F}$ are given in Table 7.A.IV. Post-test strain measurements are also included in this table. As reported previously, these burst pressures are comparable to that of the control specimen at $900^{\circ} \mathrm{F}$ but somewhat lower than that of the control at $1450{ }^{\circ} \mathrm{F}$.

TABLE 7.A.IV. Irradiation History and Postirradiation Properties of Specimens from PNL-59 Series Fuel Pins.

\begin{tabular}{|c|c|c|c|c|c|c|}
\hline $\begin{array}{c}\text { Specimen } \\
\text { Identification } \\
\end{array}$ & $\begin{array}{l}\text { Mean Cladding } \\
\text { Temperature } \\
\end{array}$ & Cladding Fluence & Test Temp & $\begin{array}{c}\text { Burst } \\
\text { Pressure } \\
\end{array}$ & $\begin{array}{c}\text { Hoop } \\
\text { Stress } \\
\end{array}$ & $\begin{array}{l}\text { Strain } \\
0 \triangle D / D\end{array}$ \\
\hline $59-7: \quad L$ & $730^{\circ} \mathrm{F}$ & $\begin{array}{l}2.7 \times 10^{20} \mathrm{n} / \mathrm{cm}^{2} \\
(\mathrm{E}>0.18 \mathrm{MeV})\end{array}$ & $1450^{\circ} \mathrm{F}$ & 3580 psi & $26,280 \mathrm{psi}$ & $12.4 \%$ \\
\hline $59-7: \quad E$ & $640^{\circ} \mathrm{F}$ & $\begin{array}{l}2.35 \times 10^{20} \mathrm{n} / \mathrm{cm}^{2} \\
(\mathrm{E}>0.18 \mathrm{MeV})\end{array}$ & $900{ }^{\circ} \mathrm{F}$ & 8920 psi & $65,470 \mathrm{psi}$ & $11.8 \%$ \\
\hline
\end{tabular}

b. Fue 1 Pin Power G. E. Culley (750)

Analysis of the thermocouple data collected during the irradiations of the twelve PNL-59 capsules is in progress. Fuel pin power as a function of time and accumulated burnup was obtained. Table 7.A.V presents the results. 
TABLE 7.A.V. GETR CapsuZe CaZculated Performance

\begin{tabular}{|c|c|c|c|}
\hline \multirow[b]{2}{*}{ Capsule } & \multirow{2}{*}{$\begin{array}{l}\text { Axial Peak } \\
\text { Power (kW/ft) } \\
\end{array}$} & \multicolumn{2}{|c|}{ Burnup (MWd/tonneM) } \\
\hline & & Axial Peak & Axial Avg. \\
\hline PNL-59-1 & 13.87 & 18,617 & 13,810 \\
\hline PNL- $59-2$ & 14.07 & 18,537 & 13,750 \\
\hline PNL- $59-3$ & 14.56 & 19,277 & 14,298 \\
\hline PNL- $59-4$ & 14.16 & 18,647 & 13,832 \\
\hline PNL- $59-5$ & 13.64 & 18,505 & 13,653 \\
\hline PNL- $59-6$ & 14.21 & 19,544 & 14,423 \\
\hline PNL- $59-7$ & 13.52 & 68,803 & 51,376 \\
\hline PNL- $59-8$ & 13.67 & 69,440 & 51,811 \\
\hline PNL- $59-9$ & 13.99 & 72,040 & 54,117 \\
\hline PNL- $59-10$ & 13.65 & 69,823 & 52,432 \\
\hline PNL- $59-11$ & 14.73 & 68,184 & 20,904 \\
\hline PNL- $59-12$ & 13.26 & 25,992 & 19,412 \\
\hline
\end{tabular}

5. Subassembly PNL-2

L. A. Pember (750)

The PNL-2 (X032) subassembly was discharged from the EBR-II August 31,1969 , at the end of Run 37. The estimated exposure on this subassembly at discharge is 47,000 MWd/tonnem. The subassembly was disassembled at EBR-II without incident. Neutron radiography performed at TREAT indicated that all pins were intact. The only unusual items visible on the neutron radiographs were what appears to be a small amount of fuel powder in the gas annulus around the insulator pellets on two pins and one of the pins with 0.010 in. thick cladding showed appreciable bowing. The pins from this subassembly will be shipped to BNW for postirradiation examination. 
6. Subassemblies PNL-3, 4 and 5

L. A. Pember and E. O. Ballard (750)

Three 37 unencapsulated pin experimental subassemblies (25 wt: $\mathrm{PuO}_{2}-75 \mathrm{wt} \% \mathrm{UO}_{2}$, Type 304 SS cladding, 0.250 in. OD) in EBR-II are operating we11. These subassemblies had attained the following estimated burnup at the end of EBR-II Run 37 (August 31, 1969).

\begin{tabular}{lc} 
Subassembly & Burnup, MWd/tonneM \\
\hline PNL-3 (X051) & 11,700 \\
PNL-4 (X059) & 14,700 \\
PNL-5 (X054) & 25,200
\end{tabular}

The subassemblies were removed from the reactor core during the first part of EBR-II Run 38 by reason of the increased power testing which took place during this period. Following the 62.5 MW test run the subassemblies were returned to their original core positions for further irradiation.

7. Subassemblies PNL-6, 7 and 8

L. A. Pember and E. O. Ballard (750)

Subassemb1y PNL-7 was assembled for insertion into EBR-II at the end of Run $38 \mathrm{~A}$. This subassembly contains 37 unencapsulated pins clad in 0.250 in. OD solution treated Type 316 SS. The fue 1 is $25 \mathrm{wt} \% \mathrm{PuO}_{2}-75 \mathrm{wt} \% \mathrm{UO}_{2}$. The $\mathrm{UO}_{2}$ is $45 \%$ enriched in $235 \mathrm{U}$. Following assembly the subassembly was neutron radiographed in three orientations at TREAT to provide a record of the assembled condition and to demonstrate the feasibility of neutron radiography of a 37-pin subassembly. The cladding which was used for the fabrication of PNL-6, 7 and 8 was all on the high side of the tolerance $(0.250 \pm 0.001 \mathrm{in.})$ This stacking of tolerance caused the pin bundles to be too large to fit a standard Mark H-37 flow tube and still allow the nominal 0.010-in. gap between the assembly and the flow duct. However, a slightly oversized hex tube was found and used for the PNL-7 
experiment. Additional, but slightly less oversized hex tubes were also found for the PNL- 6 and 8 subassemblies. In these cases the 8-mil clearance will not have an affect on the goal burnup of the subassemblies from a pin bundle-hex can interference standpoint.

8. (PNL-17) Instrumented Subassembly

M. K. Millhollen (750)

ANL forwarded to BNW complete sets of drawings for the conduit pin, the assembly grid, and the entire subassembly. The prints were checked in detail and marked prints were returned to ANL. Only one major problem, length of thermocouple above the fuel pin, was found. This was brought to ANL's attention and they have agreed that the dimension they specified can be changed.

The flow test on the dummy 37-pin PNL-17 subassembly was completed by ANL. ANL reported a pressure drop of 8 psi across the pin bundle at a flow of $53 \mathrm{gpm}$ which compares favorably with the BNW-calculated value of 7.9 psi:

9. Transient Irradiations

a. GE/VNC Capsules

G. E. Culley (750)

The five TREAT capsules fabricated by GE/VNC underwent qualification testing. Three of the five capsules failed the 15,000 psi hydrostatic test. The leak appeared at the epoxy seal in the head block and indications are that the leaks are in the epoxy resin rather than at the bond between the epoxy resin and the head block. A cost estimate for the necessary repairs is being generated by GE/VNC. 
BNWL - 1246

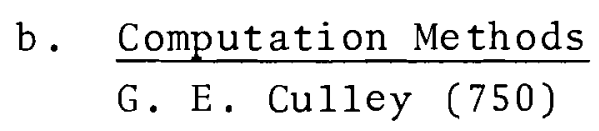

Significant progress was made in the capability to perform neutronics calculations of the fuel pins to be transient tested. These fuels contain a large portion of fissile material and a significant portion of the power is produced from nonthermal neutron-induced fissions. Thus, in addition to determining the spatial power distribution resulting from thermal neutron induced fissions, the ratio of nonthermal to thermal neutron induced fissions must be determined. The computer codes HRG and BATTELLE-REVISED-THERMOS, are being used to compute spectrum average cross sections for use in the DTF-IV code which calculates the spatial power distribution in the fue 1 . The net result is a much flatter radial power profile than is calculated when on $1 y$ the thermal fissions are considered.

\section{c. Remote Re-encapsulation}

D. O. Sheppard (750)

A remote re-encapsulation of a dummy EBR-II type fue 1 pin was successfully performed, demonstrating several untried systems and procedures.

10. Biaxial Stress-Rupture Studies for Type 316 SS Cladding R. W. Barker (722)

Biaxial stress-rupture tests on 0.208 in. diameter $x 0.008 \mathrm{in}$. wall, Type 316 SS fuel cladding in the as-received condition were begun at $900^{\circ} \mathrm{F}$. At this temperature the burst stress was 55,000 psi. A biaxial stress-rupture test was begun at $900^{\circ} \mathrm{F}$ with a hoop stress of $52,000 \mathrm{psi}$. This test has now accumulated more than $1400 \mathrm{hr}$ without specimen failure. It seems apparent that creep mechanisms are not operable or rates are extremely $10 \mathrm{w}$ in this temperature region $\left(\varepsilon 0.46 \mathrm{~T}_{\mathrm{m}}\right)$. 
Therefore additional stress-rupture tests on as-received Type 316 SS at $900^{\circ} \mathrm{F}$ will not be started at this time. However, the present $900^{\circ} \mathrm{F}$ test is functioning well and will be continued.

It was determined that the burst stress at $900{ }^{\circ} \mathrm{F}$ for Type 316 SS irradiated to $1 \times 10^{22} \mathrm{n} / \mathrm{cm}^{2}$ ( $\mathrm{E}>0.1 \mathrm{MeV}$ ) at $800^{\circ} \mathrm{F}$ is $60,000 \mathrm{psi}$. Biaxial stress-rupture tests of irradiated Type 316 SS will be performed at $900^{\circ} \mathrm{F}$ in sufficient quantity to determine if creep mechanisms will be operable at stresses higher than that required to burst as-received material.

11. Damage Analysis

J. L. Straalsund (722) and H. R. Brager (AOO)

The objectives of this effort are to establish the irradiation-induced swelling characteristics of FFTF alloys, to relate fast reactor induced submicrostructural changes to corresponding changes in mechanical properties, and to develop means for data extrapolation and interpolation, using both microscopic and empirical approaches.

Three dimensional graphs were constructed to relate void size and number density to fluence and temperature for nominally unstressed solution treated Type 304 and 316 SS. The three dimensional plots provide a better perspective of the trends in microstructural features with fluence and temperature. Tentatively, these plots show that:

- The number of voids produced increases with increasing fluence and decreasing temperature.

- The void size increases with increasing irradiation temperature, but for the temperature range between 370 and $450{ }^{\circ} \mathrm{C}$ and for fluences between 0.5 and $6 \times 10^{22} \mathrm{n} / \mathrm{cm}^{2}$ the void size appears to be independent of fluence. 
The above conclusions suggest that the average void size is quickly stabilized at some limiting size which depends only on temperature. These trends need to be substantiated and clarified by obtaining more data in the high temperature and low fluence ranges. The data suggest that the fluence dependency of swelling is caused primarily by the fluence dependency of nucleation and that the temperature dependence of swelling is associated with both nucleation and growth. Efforts will be made during the next month to put these comparisons on a more quantitative basis by fitting equations to the void size and density data and comparing these with equations describing the swelling or total void volume.

In addition to aiding in the identification of trends in the microscopy data, the three dimensional plots indicate which irradiation conditions should be investigated to substantiate or clarify the indicated relationships. Thus emphasis was shifted to include examination of samples irradiated in the lower range of fast fluence, from $1 \times 10^{21}$ to $1 \times 10^{22} \mathrm{n} / \mathrm{cm}^{2}$ $\left(\mathrm{E}>0.1 \mathrm{MeV}\right.$ ) and from 370 to $620^{\circ} \mathrm{C}$.

B. MATERIALS TECHNOLOGY

1. Uniaxia1 Creep-Rupture Studies*

J. F. Bates and A. J. Love11 (AOO)

Preliminary attempts to correlate creep-rupture data of unirradiated solution treated $\left(1950^{\circ} \mathrm{F} / 1 \mathrm{hr}\right)$ Type 304 and 316 SS have shown that the expression $\dot{\varepsilon}=\mathrm{A}[\sinh (\alpha \sigma)]^{\mathrm{n}} \mathrm{e}^{-\mathrm{Q} / \mathrm{RT}}$ where $A, \alpha, n$, and $R$ are constant can be used.

$$
\begin{aligned}
& \dot{\varepsilon}=\text { minimum creep rate (in./in./hr) } \\
& \sigma=\text { applied engineering stress (psi) } \\
& \mathrm{T}=\text { temperature of test }\left({ }^{\circ} \mathrm{K}\right) \\
& \mathrm{Q}=\text { activation energy }(\mathrm{ca} / / \text { mole). }
\end{aligned}
$$

* Reported by J. C. Tobin (960) 
Studies are now in progress to evaluate in more detail the significance of this relationship. A more detailed report will be forthcoming upon conclusion of these studies.

Data on the effect of irradiation on Types 304 and 316 solution treated $\left(1950^{\circ} \mathrm{F} / 1 \mathrm{hr}\right)$ SS specimens show that the reduction in rupture life and decrease in creep rate for the Type 304 irradiated specimens, as compared to the solution treated control, is roughly the same for total fluence of both $1 \times 10^{22}$ and $4.2 \times 10^{22} \mathrm{n} / \mathrm{cm}^{2}$. However, the Type 316 specimens tested thus far show a reduction in rupture 1 ife and an increase in creep rate that is apparently strongly dependent upon the irradiation conditions. Further tests, which should aid in the understanding of this observation, are in progress.

Weldment specimens have been irradiated in EBR-II to a fluence of $\sim 9 \times 10^{21} \mathrm{n} / \mathrm{cm}^{2}$ and are being prepared for creeprupture testing in the hot cell in $321 \mathrm{~A}$ Building. Specimens of the following types of weld processes are being prepared:

(1) Sub-Arc, (2) Stick Electrode, (3) TIG, and (4) MIG.

2. High Strain Rate Effects*

J. M. Steichen (AOO)

Several high strain rate tests on 304 SS have been completed. These tests were performed at a strain rate of $10 \mathrm{in./in./sec}$ at test temperatures from room temperature to $1400^{\circ} \mathrm{F}$. The preliminary data gave the following results:

- A comparison of strain rate effects on strength of Type 304 SS at temperature shows that ultimate strength is affected more than yield strength. At test temperatures of $800^{\circ} \mathrm{F}$ and above, the highest values for the ultimate strength are obtained at a strain rate of $0.1 \mathrm{sec}^{-1}$. As the strain rate is increased to 1.0 and $10.0 \mathrm{sec}^{-1}$, a drop is observed in the ultimate strength.

* Reported by J. C. Tobin (960) 
- Uniform and total elongation of Type 304 SS show little sensitivity to strain rate change other than to suggest slight ductility decreases with increasing rates.

- If strength values are plotted against strain rate, the room temperature ultimate and yield strengths are observed to increase as strain rate increases. The ultimate strength appears to increase about 1500 psi for each order of magnitude increase in strain rate, while the yield strength appears to increase about 2500 psi for each order of magnitude increase in strain rate. At $1000^{\circ} \mathrm{F}$, the ultimate strength increases as strain rate is increased to $0.1 \mathrm{sec}^{-1}$. At rates above $0.1 \mathrm{sec}^{-1}$ the ultimate strength decreases significantly. The yield strength at $1000^{\circ} \mathrm{F}$ decreases only slightly at the higher rates.

3. Radiation Effects on Absorbing Materials for Control Rods* A. L. Pitner (AOO)

Post-irradiation analysis is continuing on the boron carbide samples from the first thermal reactor subassembly discharge. Five forms of $\mathrm{B}_{4} \mathrm{C}$ are being investigated: 60 and $80 \%$ TD powder, and 65, 90 , and $99 \%$ TD pellets. Burnup values were obtained by mixing each powder sample thoroughly (because of the high surface reaction rate), and performing mass spectrographic analyses of boron isotopic ratios. Temperatures were assigned to the fifteen samples in accordance with those inferred from five thermocoupled capsules.

In general, the results show that gas release increases with increasing irradiation temperature. The $99 \%$ TD pellets appear to retain the helium gas more than the other sample forms.

* Reported by J. C. Tobin (960) 
The visual appearance of the pellet samples showed significant deterioration from the irradiation. This was particularly true for the $99 \%$ TD pellets. These pellets swelled during irradiation and had to be forced out of their holders. Most of the pellets had broken into smaller pieces. Corners were rounded and cracks were prominent. The surface of the $99 \%$ TD pellets was quite powdery, while the surfaces of the lower density pellet, chipped easily. Densities of several of the pellet particles were measured by immersion weighing. After irradiation, the pellets all showed apparent densities near the theoretical value $\left(2.52 \mathrm{~g} / \mathrm{cm}^{3}\right)$, indicating that the porosity and cracks generated during irradiation are easily accessible to water.

Two more subassemblies are continuing under irradiation at similar temperatures, and will be discharged to yield data at $\sim 10$ and $15 \% \mathrm{~B}^{10}$ burnup. In addition, another capsule assembly operating at temperatures from 400 to $700{ }^{\circ} \mathrm{F}$ is being irradiated to similar burnup levels.

The X042-A subassembly was removed from the EBR-II after $\checkmark 3 \% \mathrm{~B}^{10}$ burnup and $\sim 15 \times 10^{21}$ nvt tantalum exposure. These values are approximately double that attained before the first interim discharge. Neutron-radiography measurements showed that the poison column lengths of the two capsules $\mathrm{BC}-2$ and $\mathrm{BC}-5$ have returned to their original unirradiated values after showing apparent growths of $0.51 \%$ and $0.26 \%$ respectively, at the time of the first interim discharge. Capsules $\mathrm{BC}-3$ and $\mathrm{BC}-8$, which were charged after the first interim examination, showed column length changes of $+0.52 \%$ and $-0.51 \%$. Accuracy of the measure ments is considered to be $\pm 0.26 \%$ ( $1 / 64$ inch). Neutronradiography measurements of a tantalum sample that has been irradiated since the original test insertion showed a length change of $+0.25 \%$. This is approximately double the growth seen at the first interim discharge. 
4. $\underline{B}_{4}$ C - Sodium Compatibility*

L. R. Bunne11 (AOO)

Analys is by spark-source mass spectroscopy of Type 316 SS sodium-bonded to $\mathrm{B}_{4} \mathrm{C}$ pellets and heat treated at $300{ }^{\circ} \mathrm{C}$ and $500{ }^{\circ} \mathrm{C}$ for $3450 \mathrm{hr}$ showed decreasing boron and carbon transport with increased pellet density, as would be expected simply on the basis of surface area considerations. Little ot no temperature dependence is evident in the data.

$\mathrm{B}_{4} \mathrm{C}$ pellets of three densities irradiated in a thermal reactor to a nominal burnup of $3 \%$ have recently been received. The pellets swelled inside the stainless steel container and had to be pressed out. One pellet was left in place and an attempt will be made to polish the sample and thus observe a possible reaction product microstructure at the interface between $\mathrm{B}_{4} \mathrm{C}$ and the Type 304 SS. Metallography was performed on the as-received $\mathrm{B}_{4} \mathrm{C}$ pellets to provide a comparison for later work on the irradiated pellets. The two lower-density pellets had a uniform microsturcture and it is evident that a coarse hot-press feed was used. Metallic particles observed contained iron and chromium, and are probably stainless steel introduced during grinding. Open and closed porosity was obtained by a water impregnation method.

Metallography is now being performed on the irradiated pellets. X-ray analysis of some of the "crust" of high burnup material on external surfaces showed $\mathrm{B}_{4} \mathrm{C}$ peaks, plus weak peaks which could not be ascribed to lithium boride or lithium carbide.

* Reported by J. C. Tobin (960) 

CHAPTER VIII. FUELS RECYCLE

(See Appendix A for List of Author Codes Used in this Report.)

A. FUEL TECHNOLOGY

1. FFTF Fue1 Procurement

J. F. Williams (712)

The progress of the LMFBR fuel supplier prequalification contractors is as follows:

Babcock and Wilcox completed the blending of mixed oxides into five process batches and added binder to all batches. The first batch of pellets was pressed and started through sintering.

NUMEC processed the $\mathrm{PuO}_{2}$ to the point where they are ready to start mixing the two oxides. Release to blend a small batch of mixed oxides for sintering tests was granted, based on a preliminary review of procedures submitted to date.

United Nuclear Corporation was released to blend the $\mathrm{UO}_{2}$ and $\mathrm{PuO}_{2}$. This is currently in progress. Fabrication of metal components through a subcontractor was started. $\mathrm{UO}_{2}$ insulator pellets were completed and are undergoing final inspection.

NUMEC, UNC, and Babcock and Wilcox reported some quality problems with tubing. NUMEC indicated a problem with burrs on the end of the tubing plus the presence of some unidentified foreign matter in the bore. UNC reported burrs on the end of tubing, and some internal contamination. Babcock and Wilcox reported some contamination on the interior surface of tubes. Babcock and Wilcox accepted sufficient tubes to complete the required number of pins. Replacement tubing will be supplied to NUMEC and UNC when BNW inspection is complete. 
BNWL - 1246

2. LMFBR Fue1 Development - Offsite Technical Direction

B. R. Hayward (711)

Test sintering batches of mixed oxide powders under NUMEC Task 7 yielded pellets with low oxygen-to-metal ratio and high nitrogen ( 1.93 and $1200 \mathrm{ppm}$, respectively). NUMEC subsequently modified the sintering equipment to provide a controlled moisture addition.

NUMEC is using methylcellulose additions for pellet density control. The test batches for density control yielded erratic results. Larger test batches are planned in an attempt to solve this problem.

Subassemb1y X012 containing 19 NUMEC mixed oxide encapsulated pins was removed from EBR-II and disassembled for interim examination. The average burnup was $87,000 \mathrm{MWd} /$ tonne $(9.3 \mathrm{at} . \%$ ). Neutron radiographs of the pins indicated no unusual conditions or failed pins. Minor evidence of cladding ridging was observed. Copies from these neutron radiographs will be submitted to Philco-Ford for image enhancement evaluation. It is intended that some of these pins will be reinserted for burnup to $100,000 \mathrm{MWd} /$ tonne or, possibly, 150,000 MWd/tonne.

The Phase II analytical chemistry results from AI, Babcock and Wilcox, United Nuclear, General Electric Company, BNW, and NUMEC are now being compiled and evaluated at both BNW and LASL. NUMEC submitted only partial results because of analytical equipment problems. LASL has completed the work but has not yet submitted the report. The compilation of results should prove interesting since a cursory examination indicates discrepancies among certain analyses. 
3. Development and Control of Pellet Homogeneity Inspection and Testing

D. A. Stranik (740)

A method for quantitative measurement of fuel pellet homogeneity has been developed which in turn has resulted in the development of an improved homogeneity specification.

Quantitative characterization of the fuel pellet matrix was accomplished by scanning the pellets with the electron microprobe for $\mathrm{PuO}_{2}$ concentration, sizes of $\mathrm{PuO}_{2}$ enriched or depleted zones, and separation distance of such zones. This technique enabled a mathematical model to be developed relating fuel pellet characteristics to a figure of merit which describes the homogeneity of mixed oxide fuel in terms of the degree of uniformity of energy deposition (or temperature rise) under transient conditions in the $\mathrm{UO}_{2}$ content of the fuel.

A mean value of the figure of merit, $\bar{M}$, equal to or greater than 0.8 was established by FFTF Project Nuclear Analysis Section as adequate to meet FTR fuel homogeneity requirements.

The microprobe data from three $\left(\mathrm{Pu} .25 \mathrm{U}_{.75}\right) \mathrm{O}_{2}$ fuel pellets with three different degrees of inhomogeneity were analyzed according to the homogeneity method model given above. Pellet 8131 was a typical irradiation test pellet used in PNL-3 fuel pins. Pellet 956 was a pellet with less ballmilling of the powder and was used to break in new processing equipment. Pellet 8235 was a pellet in which the powder was " $V$ " blended only.

The $99 \%$ confidence limit for $\bar{M}$ for the three pellets indicates that all three are significantly greater than $\bar{M}=0.8$ which has been established as the lower limit of acceptance. 


\section{B. CLADDING TECHNOLOGY}

1. Vendor Qualification

R. C. Aungst and J. C. Tverberg (721)

Al1 comments from the various LMFBR Contractors on the Fue1 Cladding Product Description A-0086 were received and evaluated. Perhaps the most persistent criticism was directed at the inclusion of product, process, and test method specifications within a single document. All of these comments will be considered when the revised product description is rewritten and issued as the controlling document for the Vendor Qualification Program.

2. LMFBR Fuel and Cladding Center

F. R. Shober (723)

The LMFBR Fuel and Cladding Information Center is designed for computer storage and retrieval of data pertaining to the complete material, fabrication, irradiation, and postirradiation histories of LMFBR type fuel pins. The data fields frequently in place or being programmed are cladding fabrication, fuel fabrication, fuel pin fabrication, fuel subassembly fabrication, irradiation history, and postirradiation examination. Under consideration are two complementary sections to the system, one pertaining to document references and another related to materials and process specifications. The reference section will provide the necessary documentation for summary reports to be published by the center, and the specifications section will provide historical continuity between manufacturing processes and product performance. The latter will be tied closely with quality assurance activities.

The information and fields for fue 1 pin data were arranged in an hierarchical order within their respective sections to maintain compatibility in the system and to permit selective 
accessibility and storage of data. The program format and data input forms are also being prepared for the fuel pin section.

Entries made in the LMFBR file include data from 107 tensile tests in the austenitic stainless steel file and data for 18 tensile tests from $\mathrm{N}-1$ lot of tubing in the cladding characterization file. This brings their respective totals to 2,323 and 231. Data from 30 creep tests were added to the creep data file. Plots made of the creep data to test the system indicated the need for only minor changes in the program. Further check of the program will be made by retrieving the data from these 30 creep tests and plotting their strain versus time graphs. The files now contain the results of 6541 tests, with most of them being tensile tests.

C. FUEL PIN TECHNOLOGY

1. NDT Systems Development - Ultrasonic Test for Fue 1 Pin Welds J. L. Thompson (MOO), J. Ryden (MOO), R. M. Crawford (733), and A. C. Callen (740)

Five sample fuel pin end closure welds were previously made to achieve some degree of lack of penetration. The initial ultrasonic examination indicated several possible areas with less than full weld penetration. Radiographic examination of the sample welds indicates that the ultrasonic test detected tiny pockets at the tube ID-cap interface. Metallography of the samples will be made to confirm the nature and size of the indicated defects.

2. Cladding Test Round Robin

W. F. Stevenson (740)

Twelve cladding tubes of Type 316 SS 0.230 in. OD, 0.015 in. wall thickness by $5 \mathrm{ft}$ long have been shipped to United Nuclear Corporation for the purpose of qualifying a subcontractor for performing ultrasonic testing of cladding 
tubes on subsequent contracts. These same tubes are to be tested by those other organizations participating in the prequalification program. Data from these tests will be analyzed to determine precision and accuracy.

3. Irradiation Test Pin Fabrication

R. M. Crawford (733)

Twenty fuel pins for EBR-II subassembly PNL-6 were loaded, xenon tagged and welded. Sixteen additional pins are loaded and ready for tagging and welding.

4. Fuel Pin End Closure Development

R. M. Crawford (733)

To date, approximately 2100 fuel pin end closures using the reference FTR weld design have been welded and radiographed. About $5 \%$ of these welds were examined metallographically. Metallographic examination revealed no evidence of any condition that would cause the weld to be rejected in any of the 81 welds examined.

Radiographs of all the pin closure welds for irradiation in EBR-II were examined and accepted by the quality assurance group at EBR-II.

Approximately $50 \%$ of the welds produced to date have had a build-up across the diameter of $0.001-i n$. or less and $95 \%$ of the welds have had a build-up on the diameter of 0.0025-in. or less. While 37 of the 2100 welds made were rejected for incomplete (less than $100 \%$ ) penetration based on radiography, none of the 81 welds submitted for metallography showed incomplete penetration. 
The following is a summary of the welds made to date:

Irradiation Test Pins for PNL-3, 4, 5-0.250 in. OD Type 304 SS

Total Welds - 376

Metallography - 19

Weld Rejects - 6 unable to close, 5 incomplete penetration, $20 \mathrm{Pu}$ contaminated greater than $500 \mathrm{~d} / \mathrm{m}$ - Total 31 .

CCTL Test Pins -0.250 in. OD - Type 304 SS

Total Welds - 677

Metallography - 5

Weld Rejects - 2 unable to close, 4 incomplete penetration - Total 6 .

Irradiation Test Pins for PNL-7, $8-0.250$ in. OD - Type 316 SS

Total Welds - 216

Metallography - 12

Weld Rejects - 0

Irradiation Test Pins for PNL-17 - 0.230 in. OD - Type 316 SS 20\% Cold Worked C1adding

Total Welds - 97

Metallography - 5

Weld Rejects - 1 incomplete penetration

Physics Test Pins - 0.230 in. OD - Type 316 SS 20\% Cold Worked Cladding

Total Welds - 727

Metallography - 40

Weld Rejects - 27 incomplete penetration, 13 tungsten inclusions, 2 porosity, 6 concavity, 4 other - Total 52. 
It was necessary to increase the welding current approximately $14 \%$ to achieve complete penetration when the change was made from commercially available Type 316 SS to vacuum melted Type 316 SS end cap material. The vacuum melted end cap material which is the reference material for FFTF was used in the end caps for PNL-17 and the physics test pins.

The emphasis on the welding development program in the immediate future will be on: (a) the effect of end cap machining tolerances and end cap-to-tube fit on the completed weld and (b) an intensive physical testing program on the completed welds. This testing program will be similar to the program currently in progress for the fuel pin cladding and will include tensile tests, stress rupture tests, and burst tests.

D. FUEL SUBASSEMBLY TECHNOLOGY

1. Fabrication Technology

a. Project Status M. D. Jackson (732)

Project BCP-034 (Fuel Subassembly Fabrication Demonstration Facility) provides for a facility for demonstrating fabrication methods to assemble fast reactor fuel pin subassemblies.

Work in Room 231, Building 308, progressed we11. The cleaning tanks and air dryer are being connected to the building utilities. The installation of the fuel bundle storage cylinders in Room 138 is approximately 75\% complete. The doorways connecting Rooms 132 and 138 are complete. The overall project construction is $80 \%$ complete and on schedule.

Project BAP-022 (Plutonium Fuel Laboratory Addition) provides for special facilities required for initial storage, handling, testing, assembly, and instrumentation of nonirradiated fuel. 
BNWL -1246

The design work of this project is $50 \%$ complete and on schedule. Completion of the design phase of this project is scheduled for November 15, 1969.

b. Wire-End Cap Termination Weld (3/32 in. fillet type) Evaluation R. L. Myers (732)

Oxalic acid etch tests on six wire-to-end cap weld samples were completed. The samples included two each with the weld parameters set for minimum acceptable penetration, mid-range values, and maximum acceptable penetration for a total of six samples. The results show a definite step structure. Thus, the welding technique does not increase susceptibility to intergranular attack. Good corrosion resistance is therefore maintained.

\section{Fue1 Examination - System Group 70}

a. CFDD No. 71

E. B. Ramsey (942)

Changes to the base section of the published Inert Gas Ce11 Examination Facility CFDD No. 71 were approved by RDT subject to resolution of comments. RDT comments were incorporated and revised pages are being prepared for distribution.

b. Disassembly-Reassembly Equipment

W. S. Chenault and E. B. Ramsey (942)

The requirement for this equipment is to make provisions for the remote disassembly and reassembly of those irradiated core components and test assemblies requiring examination and evaluation.

Work has been initiated at ORNL to identify the impact of the proposed test assembly length reduction on examination facility related requirements for disassembly-reassembly of FFTF tests. The documentation of this work will be published 
as an addendum to the "Conceptual Study of DisassemblyReassembly Equipment for Examination of FFTF Core Components."

c. Fuel Examination Gas Cooling Tests J. M. Yatabe (913), D. R. Dickinson, T. C. Reihman, and R. A. Hildner (COO)

The objective of this program is to determine the requirements for gas cooling of fuel assemblies during removal from the reactor and during postirradiation examination. Work done last fiscal year on this task showed that axial and transverse flow interactions allowed hot spots to exist in the fuel assembly (an electrically heated 169-pin bundle - - 0.250-in. pins wrapped on a 12 -in. pitch with $0.030-i n$. wire - the heated section is 36 in. long) using positive displacement of the gas.

It has been proposed that the Fuel Examination facility be modified to allow axial gas flow in suction rather than by positive displacement. Suction flow should prevent hot spots which resulted with positive displacement flow, and should also control foreign contaminants in the gas. 
BNWL - 1246

CHAPTER IX. PHYSICS

(See Appendix A for List of Author Codes Used in This Report.)

A. CORE PHYSICS

1. FTR Critical Experiments

a. FTR-2 Experiments in ZPPR

R. A. Bennett (833)

Shielding and core experiments being carried out in the FTR- 2 critical assembly in ANL's ZPPR are on a schedule with a predicted completion date of November 19, 1969. No problems have been identified that will interfere with the scheduled completion.

b. FTR-3 Experiments

R. A. Bennett (833)

Preliminary plans for the conduct of two-zone core experiments in the FTR-3 Critical Experiment program have been prepared by ANL personnel and are being reviewed by BNW personnel.

If authorization for plutonium is not received early in November, it is expected that the FTR-3 program will be carried out in ZPPR.

c. Analysis of FTR-2 Experiments on the ZPPR J. V. Nelson (833)

The FTR-2 reference loading (1-70) contains $527.04 \mathrm{~kg}$ fissile material and is 102.5 Ih supercritical with all fuel control rods fully inserted. The multiplication constant of this loading was calculated to be 0.98713 , using $2 \mathrm{DBS}$ in $\mathrm{X}-\mathrm{Y}$ mode and a 13-group cross section set. After correcting to $\mathrm{S}_{12}$ transport theory and for core heterogeneity, the calculated $\mathrm{k}_{\text {eff }}$ was $1.0036(\mathrm{c} / \mathrm{e}=1.0026)$. Similar results were obtained for loading 1-52 which was measured to be $83 \$$ subcritical. The final corrected $2 \mathrm{DB}, \mathrm{X}-\mathrm{Y} \mathrm{k}_{\mathrm{eff}}$, was 1.0003 and the corresponding $c / e$ value was 1.0029 . 
The edge worth of fuel relative to radial reflector material, keeping the number of $\mathrm{B}_{4} \mathrm{C}$ control ring drawers constant, was calculated for two drawers and compared to the measured values. The results are shown in Table 9.A.I.

The radial reaction rates for ${ }^{239} \mathrm{Pu}, 238^{\mathrm{U}}$, and ${ }^{10} \mathrm{~B}$, were measured in FTR-2 through Row $137,3.036$ in. above the midplane.

\section{TABLE 9.A.I. Fuel Edge Worths, FTR-2 on ZPPR}

\begin{tabular}{|c|c|c|c|c|c|}
\hline $\begin{array}{l}\text { Matrix } \\
\text { Position } \\
\end{array}$ & $\begin{array}{c}\text { Fissil } \\
\text { Mass, } \\
\mathrm{kg}\end{array}$ & Exchanges & $\frac{\text { Worth of Exc }}{\text { Experimental }}$ & $\frac{\text { hange, Ih }}{\text { Calculated }}$ & $\mathrm{c} / \mathrm{e}$ \\
\hline 130,29 & 1.0116 & Core for C.R. & +27.25 & +30 & 1.09 \\
\hline 129,28 & & $C \cdot R$. for R.R. & & & \\
\hline 128,32 & 0.5088 & C.R. for Core & -24.06 & -23 & 0.96 \\
\hline 127,31 & & R.R. for C.R. & & & \\
\hline
\end{tabular}

Both the measured and calculated activities are plotted in Figures 9.A.1, 2, and 3. The calculated reaction rates, using core averaged cross sections, and the measured data are normalized to the same value at the core center in all three plots. The calculational results were obtained from the 2DBS, 13 group, X-Y calculation of loading 1-70 mentioned above. In general, the discrepancy between measured and calculated reaction rates near the core reflector interface, which occurred in the analysis of previous cores [ZPR-3 Assemblies 48a, 51, and $\left.56 \mathrm{~b}^{(1-3)}\right]$, is not present in FTR-2. However, neither did

1. "2DBS, A Modification of $2 D B, "$ FFTF Monthly Informal Technical Progress Report, BNWL-990, Battelie-Northwest, Richland, Washington, January 1969, p. 3.54 .

2. R. A. Bennett and S. L. DeMyer, Analysis of FTR Phase A Control Rod Experiments in ZPR-III, Assemblies 48 and $48 a$, BNWL-967, Battelle-Northwest, Richland, Washington, Apriz 1969.

3. W. R. Young and R. A. Bennett, Analysis of FTR Phase $B$ Critical Experiments, Part 1, ZPR-III, Assembly 51, BNWL-1138, Battelle-Northwest, Richland, Washington, August 1969 . 


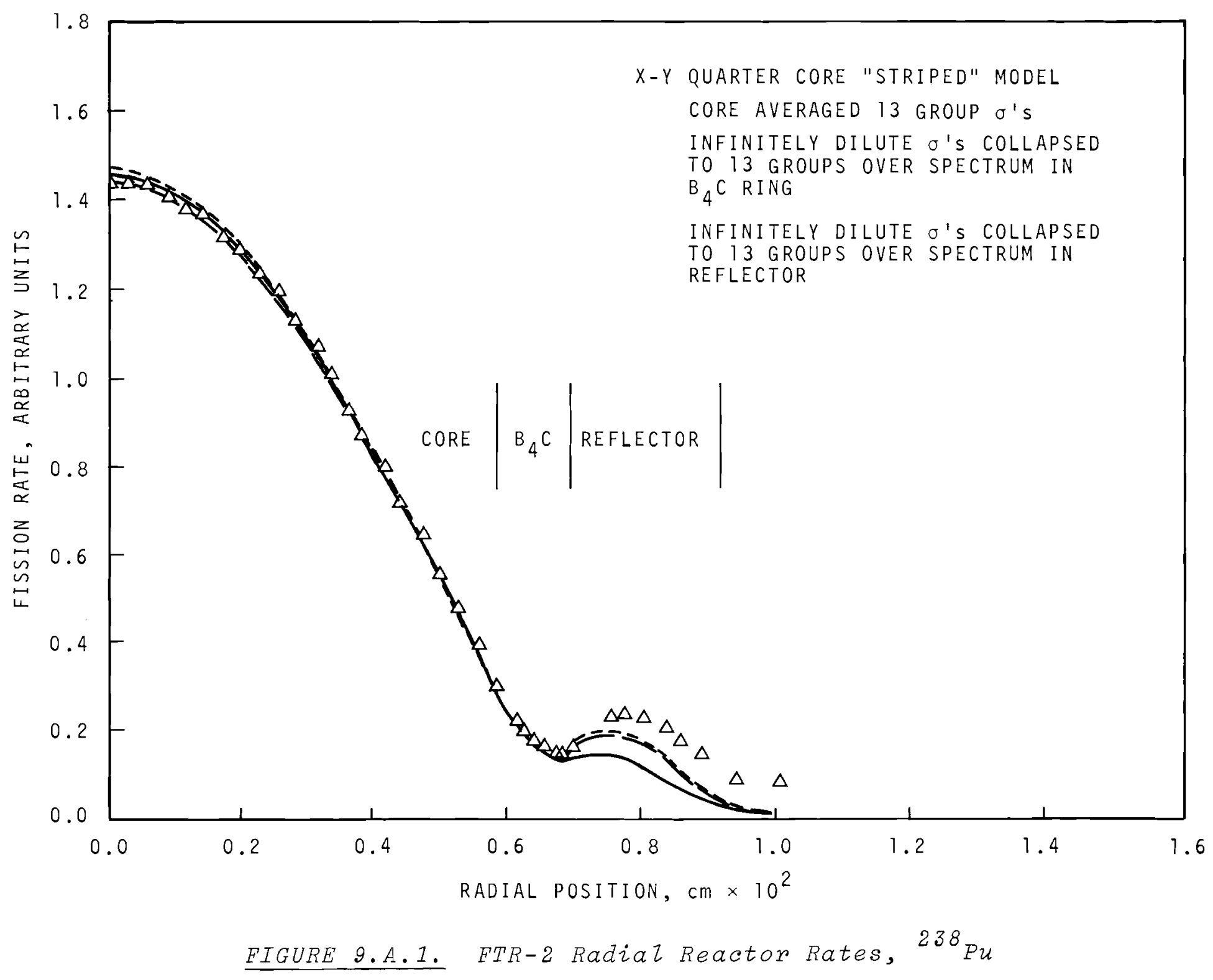

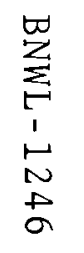




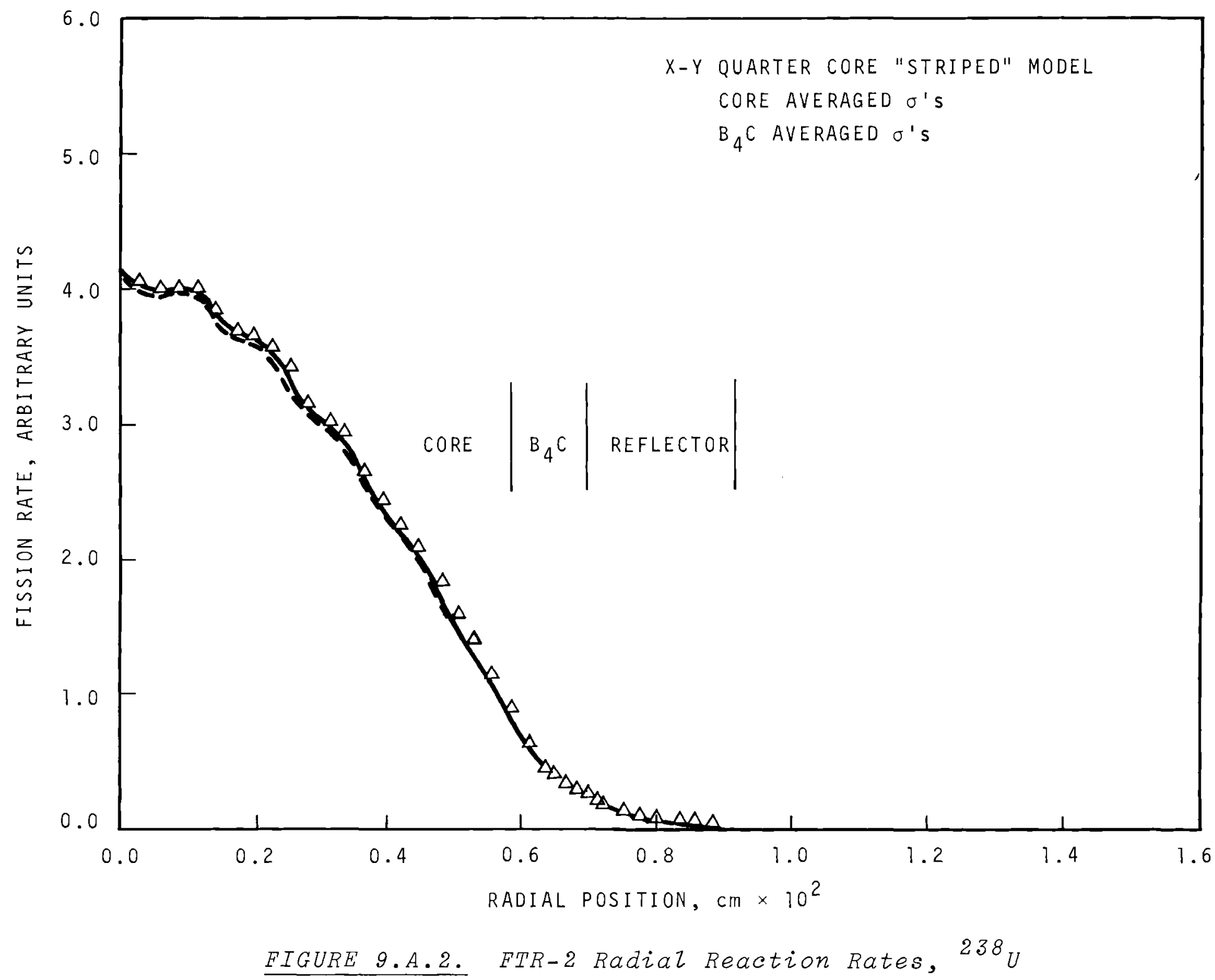

FIGURE 9.A.2. FTR-2 Radial Reaction Rates, 


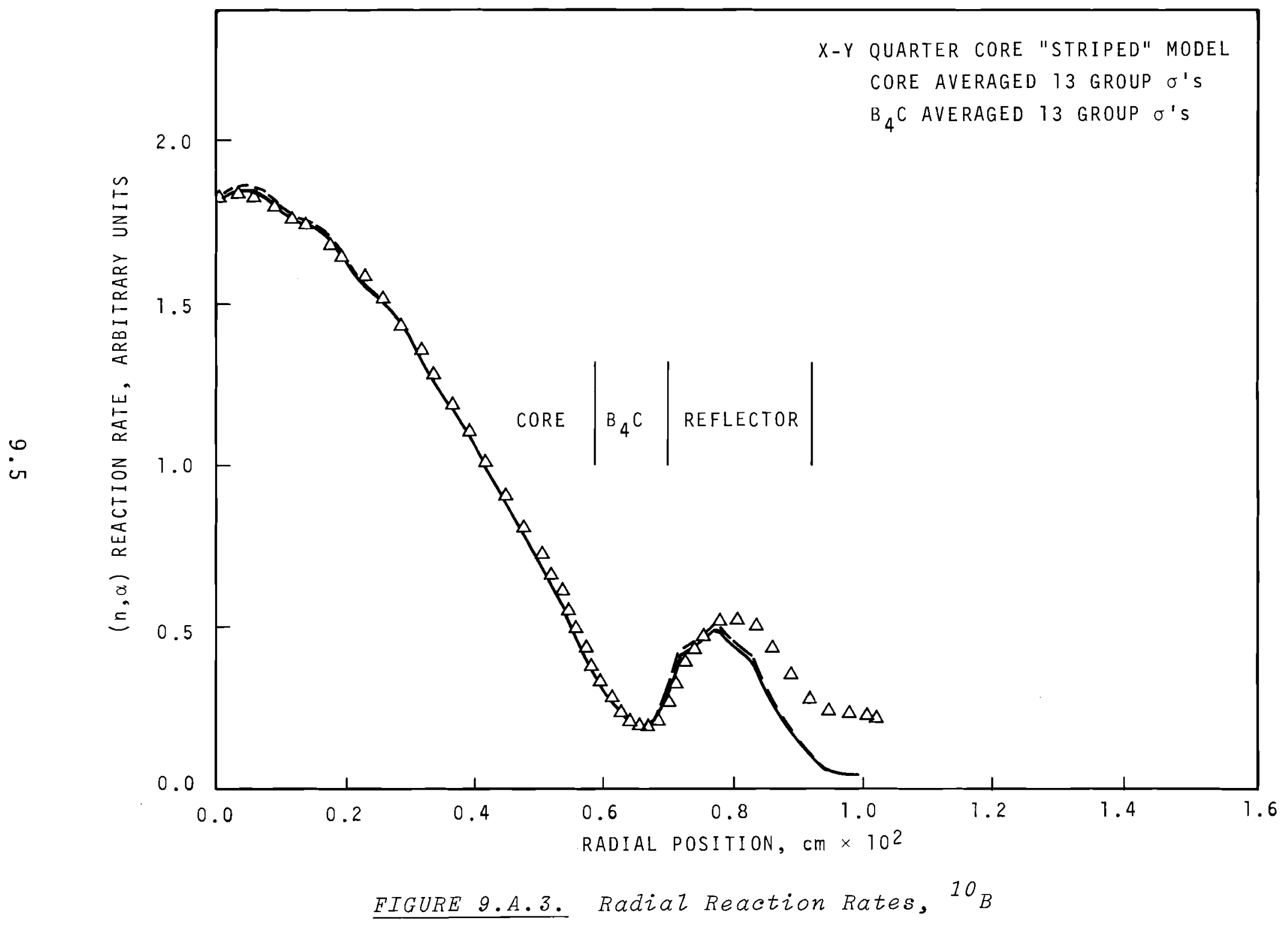

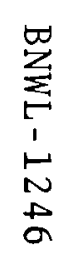


the discrepancy occur in Assembly 48a when traverses were taken through a peripheral control rod. Both the calculated ${ }^{239} \mathrm{Pu}$ fission rates and the ${ }^{10} \mathrm{~B}(\mathrm{n}, \alpha)$ reaction rates are considerably lower than the measured values throughout the reflector. One possible source of error, being investigated presently, is that the effect of the matrix structure outside the reflector is not accounted for in the calculational model.

The worth of the control ring was calculated in $2 \mathrm{DB} X-\mathrm{Y}$ and $R-Z$ geometries. The worth computed in $R-Z$ mode was $-4.84 \%$ $\Delta \mathrm{k} / \mathrm{k}$ while the $\mathrm{X}-\mathrm{Y}$ result was $-4.83 \% \Delta \mathrm{k} / \mathrm{k}$.

d. $\frac{\text { ZRP-3 Peak-to-Average }{ }^{239} \mathrm{Pu} \text { Fission Rate }}{\text { V. O. Uotinen (COO) }}$

The ratio of peak-to-average ${ }^{239} \mathrm{Pu}$ fission rate has been determined from measured and calculated fission rate traverses in ZPR-3 Assemblies 48a, 51, and 56b. For these assemblies, the peak-to-average ratio is consistently overestimated by the calculation. The average calculated radial peaking factor is 6.5 to $9.2 \% \mathrm{high}$; the average calculated axial peaking factor is $3.5 \% \mathrm{high}$; the overall peaking factor is 10 to $13 \% \mathrm{high}$.

\section{e. FTR-3 Preanalysis \\ S. L. DeMyer (833)}

Material compositions and the reference reactor configuration for the FTR-3 Critical Experiments program are tentatively approved. $(1,2)$ This will be a 2 -zone core approximating a homogenized version of the FTR reference design. Preanalysis of this assembly is nearing completion.

1. R. A. Bennett. Unpublished Data. Battelle-Northwest, Richland, Washington, September 4, 1969. (Personal Communication to A. Trave Zli, "Required FTR-3 Experiments, Supp 2. No. 1," BNW-FFTF-692557.)

2. A. Travelzi. Unpublished Data. Argonne National Laboratory, Argonne, IZlinois, September 29, 1969. (Personal Communication to R. A. Bennett, "Detailed Plans for FTR-3 Experiments," ANL-69-188.) 
Some calculated characteristics are given in Table 9.A.II.

TABLE 9.A.II. Calculated Characteristics

and Values of Material Compositions

1. Fissile Mass, $\mathrm{kg}$

2. Core Volume, 1iters

3. Effective Multiplication Constant

4. Controls: $16-4 \times 4$ in. 32 vol\% Natural $\mathrm{B}_{4} \mathrm{C}$, worth, : $\Delta \mathrm{k} / \mathrm{k}$

5. Controls: $5 \mathrm{~cm}$ thick ring, 32 vol\% Natural $\mathrm{B}_{4} \mathrm{C}$ worth, $\triangle \mathrm{k} / \mathrm{k}$

6. Controls: $16-4 \times 4$ in. 48 vol\% Natural $B_{4} C$ worth, : $\Delta \mathrm{k} / \mathrm{k}$

7. A $16 \%$ increase in 238 U content of outer zone, worth, $\frac{\circ}{6} \Delta \mathrm{k} / \mathrm{k}$

8. A 2 vol\% reduction (22 1iters) in core volume at the outer edge of outer zone, worth, $\Delta \mathrm{k} / \mathrm{k}$

9. Redistribution of $16-4 \times 4$ in. control zones in an array of 8 sets of two closely spaced zones, worth, $: \Delta \mathrm{k} / \mathrm{k}$

f. ETOX

R. B. Kidman ( $\mathrm{COO})$

Both ETOX (IDX) and $M C^{2}$ have generated multigroup cross sections for ZPR-III Assembly 52. A comparison shows good general agreement but a few differences exist, and those occurring in the resolved and unresolved region of ${ }^{239} \mathrm{Pu}$ are being investigated.

The fission cross sections for Groups 13 (15 to $24.8 \mathrm{keV}$ ) and 20 (454 to $749 \mathrm{eV}$ ) were calculated in two ways by ETOX: (1) Using the ETOX unresolved approximations. (2) Using the $\mathrm{MC}^{2}$ unresolved approximations. Since the resulting cross sections were insignificantly different, it appears that the different approximations will not account for the present ETOX $-\mathrm{MC}^{2}$ differences in ${ }^{239} \mathrm{Pu}$. 
The effect of varying the number of fine intervals for any coarse group had to be examined since ETOX and $\mathrm{MC}^{2}$ vary in this respect. Changing the fine interval size did not change the ETOX value for Group 13. However, for Group 20, the ETOX value changed by approximately $2 \%$. Group 13 has smooth floor values while Group 20 has discontinuous floor values which explains the above results. Fine interval size cannot explain the ETOX $-\mathrm{MC}^{2}$ differences for Group 13 , but, depending on how $\mathrm{MC}^{2}$ handles the discontinuities, it may explain some of the Group 20 differences.

Very often, the floor discontinuities occur at the energies separating the resolved, unresolved and smooth cross section regions. ETOX was reprogrammed so that interpolation on the floor cross sections does not occur across any of these energies. This improved the ETOX $-\mathrm{MC}^{2}$ comparison in the groups containing those energies.

The effect of ${ }^{239} \mathrm{Pu}-{ }^{238} \mathrm{U}$ resonance overlap in Group 20 was investigated by running ETOX in the following ways: (1) Using a constant effective total cross section for $238_{U}$. (2) Using a model that specifically accounted for the ${ }^{238} \mathrm{U}$ resonances. The similarity of the resulting cross sections suggests that $239 \mathrm{Pu}^{238} \mathrm{U}$ resonance overlap cannot explain the Group 20 ETOX - MC ${ }^{2}$ differences.

Group 22 (167 to $275 \mathrm{eV}$ ) is a resolved region for both ${ }^{239} \mathrm{Pu}$ and ${ }^{238} \mathrm{U}$. Resonances overlap was investigated in this group by using the BNL values for $\sigma_{t}^{238}$ and $\sigma_{t}^{239}$, and the nuclide concentrations for Assembly 52. Preliminary results indicate that the effective group total cross sections for $238{ }^{\mathrm{U}-}{ }^{239} \mathrm{Pu}$, as calculated in the $1 \mathrm{DX}$ manner, do not vary more than $1 \%$ from the values which are calculated in an exact manner (i.e., by following the exact energy variation of $\sigma_{t}^{238}$ and $\sigma_{t}^{239}$ ). 
2. Uncertainties in FTR Design Parameters

R. A. Bennett (833)

Based upon the FTR Critical Experiments conducted to date, a preliminary assessment of uncertainties in some FTR design parameters has been made. These values are summarized in Table 9.A.III. Included in the table are reasonable corresponding design allowances that are to be included in the final specification of design parameters. Statistical confidence levels are included where possible. The major exception is the FTR Doppler coefficient uncertainty which is an intuitive estimate based upon experiment-theory correlations on small sample Doppler experiments conducted in the FTR Critical Experiments program.

$$
\begin{aligned}
& \text { TABLE 9.A.III. Summary of Uncertainties } \\
& \text { in FTR Design Parameters }
\end{aligned}
$$

\begin{tabular}{|c|c|c|c|}
\hline Parameter & Value & Uncertainty & $\begin{array}{l}\text { Design } \\
\text { Allowance } \\
\end{array}$ \\
\hline Critical Mass (CM), $\mathrm{kg}$ & $\begin{array}{l}\text { Nominally } \\
530239 \mathrm{Pu}\end{array}$ & $\begin{array}{l} \pm 1.3 \% \text { of } C M \\
(95 \% \text { CL) }\end{array}$ & $\begin{array}{l}+1.3 \% \text { of the } \\
\text { Calculated } \\
\text { Critical } \\
\text { Mass }\end{array}$ \\
\hline Peak-to-Average Power & $\begin{array}{l}\text { Calculated } \\
\text { Value }\end{array}$ & $\begin{array}{l} \pm 3 \% \\
(95 \% \quad C L)\end{array}$ & $+3 \%$ \\
\hline \multicolumn{4}{|c|}{ Sodium Void Coefficient } \\
\hline Whole Core & $\begin{array}{l}\text { Calculated } \\
\text { Value }\end{array}$ & $\pm 7 \%$ & $+7 \%$ \\
\hline Central & $\begin{array}{l}\text { Calculated } \\
\text { Value }\end{array}$ & $\begin{array}{l}\text { Factor } \\
\text { of } 2\end{array}$ & $+100 \%$ \\
\hline \multicolumn{4}{|l|}{ Control Rod Worths } \\
\hline Central & $\begin{array}{l}\text { Calculated } \\
\text { Value }\end{array}$ & $\begin{array}{l} \pm 20 \% \\
(95 \% \mathrm{CL})\end{array}$ & $+20 \%$ \\
\hline Peripheral & $\begin{array}{l}\text { Calculated } \\
\text { Value }\end{array}$ & $\begin{array}{l} \pm 6 \% \\
(95 \% \mathrm{CL})\end{array}$ & $+6 \%$ \\
\hline Doppler Coefficient & $\begin{array}{l}\text { Calculated } \\
\text { Value }\end{array}$ & $\begin{array}{l} \pm \sim 50 \% \\
\sim 95 \% \mathrm{CL})\end{array}$ & $-50 \%$ \\
\hline
\end{tabular}


BNWL -1246

3. Count Rates in the Shutdown FTR

V. O. Uotinen (COO)

Subcritical source calculations have been performed to determine reaction rates at in-vessel sensor locations in the FTR. These calculations indicate that the expected count rate at $96 \mathrm{~cm}$, using a commercially available $2-i n .235_{U}$ fission chamber, is $\sim 50$ counts/second when operating in a gamma-field of $10^{6} \mathrm{R} /$ hour. According to stated design requirements, (1) a count rate as low as 10 counts/second would be acceptable. Hence, the expected count rate is more than adequate, and a startup source is not a requirement for the FTR.

Immediately following shutdown, while the gamma-field is higher than $10^{6} \mathrm{R} /$ hour, it should be possible to verify that the chamber is responding to neutrons by simply removing a safety rod or two.

B. RADIATION AND SHIELDING

1. Core Support Structure Shielding

D. R. Marr (813)

Location of core support structural members less than $5 \mathrm{ft}$ from the core will require that efficient shielding material be incorporated to reduce radiation damage to tolerable rates. Calculations were made to determine the effect of sodium penetrations, which might exist below control rods or closed loops, through a stainless steel-sodium shield. Twodimension diffusion theory calculations indicate localized total neutron flux leakage through such a penetration would be about a factor of five greater than through the shielded region. In order to substantiate the diffusion theory calculation, both a two-dimension discrete ordinates and a Monte Carlo calculation were made. Since these substantiated the

1. CSDD for System 95, p. 1.1-18, March 18, 1969. 
diffusion theory calculation, it is concluded that sodiumfilled penetrations the size of a flow channel are not tolerable through the lower axial shield region if the core support structure is to be protected adequately.

2. Gamma Distributions

D. R. $\operatorname{Marr}(813)$

Calculation of the gamma flux distribution throughout the FTR system is required to define heat generation rates and the radiation environment. In most regions external to the core, the gamma intensity is dominated by photons resulting from neutron capture. Thus, to obtain the gamma distribution, it is first necessary to calculate the neutron distribution and the corresponding spatial gamma production rates, followed by the gamma transport calculation. The necessary libraries and linking codes have now been developed to automate this process, providing a discrete ordinates oriented gamma capability.

3. Stored Fuel Effects on FTR Ex-Vessel Monitoring

E. T. Boulette (813)

The conceptual design of the FTR includes in-vessel storage of fuel subassemblies in the $\mathrm{Na}$ annulus around the radial shield. Since ex-vessel monitors are to be used for fullpower monitoring, the effect of the stored fuel on the monitor signal was investigated.

Two-dimensional diffusion theory calculations in R- $\theta$ geometry were made based on Concept V-A. A 120 degree sector with reflective boundary conditions at $\theta=0$ degrees and $\theta=120$ degrees was employed. Two large homogeneous stored fuel zones were positioned in the $\mathrm{Na}$ annulus. The larger zone, containing 11 homogenized fuel subassemblies, was 
bounded azimuthally by angles $\theta=75$ degrees and $\theta=93$ degrees; whereas the smaller zone, with 6 subassemblies, was bounded by the angles $\theta=36$ degrees and $\theta=51$ degrees.

Two calculations were made, one with the stored fuel in position, the other with the stored fuel replaced by sodium. The reaction rate distributions for ${ }^{239} \mathrm{Pu}(\mathrm{n}, \mathrm{f})$ were calculated and a comparison was made along $\theta=4.5$ degrees. The results of the comparison indicate that only about $6.5 \%$ of the signal received at the ex-vessel monitor is induced by flux from the stored fuel when the reactor is operating at $400 \mathrm{MW}$.

4. ZPPR FTR-2 Reaction Rate Calculations

E. T. Boulette (813)

A series of shield experiments are in progress on ZPPR to provide an evaluation basis for the FTR conceptual design. Two-dimensional diffusion theory calculations were made to provide guidance for the experiments. In addition to flux distributions, reaction rate distribution for $B(n, \alpha), M n(n, \gamma)$,

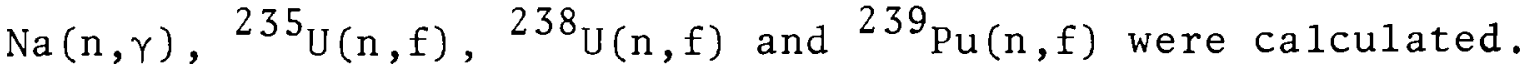
In the case of ${ }^{235} \mathrm{U}$ and ${ }^{239} \mathrm{Pu}$, reaction rate distributions calculated from core-spectrum and shield-spectrum weighted reaction cross sections were obtained and compared. Reaction rate comparisons indicate very good agreement $(<1 \%)$ in the core region, with differences no larger than about $10 \%$ exterior to the core. In the case of ${ }^{235} \mathrm{U}$, the core-spectrum weighted reaction rate was higher in the shield; whereas for ${ }^{239} \mathrm{Pu}$, the shield-spectrum weighted reaction rate was higher in the shield.

5. Dose Rates at the FTR Operating Deck

C. A. Mansius and E. T. Boulette (813)

The current personnel protection criterion ascribed at the deck location above the FTR cover is $0.2 \mathrm{mrem} / \mathrm{hr}$. Calculations were made to determine the necessary effective thickness 
of stainless steel required to satisfy this limit. Two primary sources of radiation exist. One is the neutron flux emanating from the core and the other is the gamma flux from the ${ }^{24} \mathrm{Na}$ in the sodium pool. Based on a $14.5 \mathrm{ft}$ pool, $39 \mathrm{in}$. of steel (or its equivalent) is required to reduce the neutron dose rate at the deck to about $0.1 \mathrm{mrem} / \mathrm{hr}$. This amount of steel is more than adequate for the pool gammas, giving a tota $1<0.2 \mathrm{mrem} / \mathrm{hr}$.

Another source of radiation that was considered is the closed loop piping. Calculations indicate that 20 in. of steel (or equivalent) is required to reduce the gamma intensity from four 4 -in. closed loop pipes ( 2 inlet, 2 outlet) to below $0.2 \mathrm{mR} / \mathrm{hr}$ in the region above the work deck. 
(

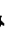




\section{CHAPTER $X$. SAFETY}

(See Appendix A for List of Author Codes Used in this Report.)

\section{A. PLANT SAFETY ANALYSIS}

1. Fau1t Tree Simulation Test

R. J. Schroder (821)

The fault trees for several protective functions in the plant protective system were evaluated using the fault tree simulation program, MFTS. These runs were for comparison with results calculated using standard reliability techniques. In general, the simulation results tend to be smaller than the hand calculated results. The differences were created primarily by a tendency for the program to underestimate unreliabilities. However, the downward bias is somewhat less than that indicated by the hand calculations since the latter were conservative.

The following cases were run using the indicated test intervals and failure rates.

\begin{tabular}{|c|c|c|c|c|c|c|c|}
\hline \multirow{3}{*}{$\begin{array}{l}\text { Protective Function } \\
\text { Low Level Neutron } \\
\text { Flux Level }\end{array}$} & \multicolumn{4}{|c|}{$168 \mathrm{hr}$ Test } & \multicolumn{3}{|c|}{$1500 \mathrm{hr}$ Test } \\
\hline & Fland & $\overline{\mathrm{Ca}} \overline{\mathrm{C}}$ & & MFTS & Hand Ca1c. & & MFTS \\
\hline & $2 \times$ & $10^{-4}$ & & $\times 10^{-4}$ & $2 \times 10^{-2}$ & 2 & $\times 10^{-2}$ \\
\hline $\begin{array}{l}\text { Low Level Neutron } \\
\text { Flux Period }\end{array}$ & $3 \times$ & $10^{-4}$ & & $\times 10^{-4}$ & $2 \times 10^{-2}$ & 2 & $\times 10^{-}$ \\
\hline $\begin{array}{l}\text { Intermed. Level } \\
\text { Flux Level }\end{array}$ & $2 \times$ & $10^{-4}$ & 1 & $\times 10^{-4}$ & $1 \times 10^{-2}$ & 1 & $\times 10^{-2}$ \\
\hline $\begin{array}{l}\text { Intermed. Level } \\
\text { Flux Period }\end{array}$ & (Sa) & me as & for & Low Leve & 1 Flux Leve & 1) & \\
\hline $\begin{array}{l}\text { Power Level Neutron } \\
\text { F1ux }\end{array}$ & $3 \times$ & $10^{-6}$ & 1 & $\times 10^{-6}$ & $2 \times 10^{-3}$ & 0.9 & $\times 10^{-3}$ \\
\hline $\begin{array}{l}\text { Power Level Neutron } \\
\text { Rate-of-Change }\end{array}$ & $4 \times$ & $10^{-6}$ & 2 & $2 \times 10^{-6}$ & $2 \times 10^{-3}$ & 1 & $\times 10^{-3}$ \\
\hline $\begin{array}{l}\text { Bulk outlet } \\
\text { Temperature }\end{array}$ & $9 \times$ & $10^{-7}$ & 4 & $+10^{-7}$ & $7 \times 10^{-5}$ & 5 & $\times 10^{-5}$ \\
\hline $\begin{array}{l}\text { Primary Loop IHX } \\
\text { Outlet Temperature }\end{array}$ & $1 \times$ & $10^{-6}$ & 0.6 & $5 \times 10^{-6}$ & $3 \times 10^{-4}$ & 2 & $\times 10^{-4}$ \\
\hline Reactor F1ux/F1ow & $2 \times$ & $10^{-5}$ & 2 & $2 \times 10^{-5}$ & $5 \times 10^{-3}$ & 8 & $\times 10^{-3}$ \\
\hline $\begin{array}{l}\text { Reactor Vesse } 1 \\
\text { Coolant Level }\end{array}$ & & as & or & Primary & IHX Te & & 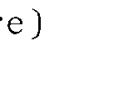 \\
\hline
\end{tabular}


2. Multiple Protective Function Failure

R. J. Schroder (821)

Several possible accidents are subject to detection by more than one protective function. The probability of failure of two or more protective functions for two cases was investigated using MFTS. Nominal failure rates and a test interval of $168 \mathrm{hr}$ were assumed in each case. Only independent component failures were considered. The results should be viewed accordingly. The following unavalabilities were found.

Low Level and Intermediate Level Neutron Flux $1 \times 10^{-7}$ Power Level and Intermediate Level Neutron Flux $1 \times 10^{-9}$ The above results can be used to conclude that if only independent component failures are considered the unavailabilities for any other pair of protective function (except those with common components) are about $10^{-9}$ or less. The unavailability of a pair of protective functions having common elements (e.g., power level flux level and flux-flow) is about equal to, but a little better (lower) than, the unavailability of the more reliable of the two.

The only conclusion that should be reached is that component failures will not make a significant contribution to the unavailability of multiple protective functions unless common components are involved.

\section{B. ANALYSIS OF HYPOTHETICAL ACCIDENTS}

1. Containment Transients

R. D. Peak (821)

The CAVCEL digital computer code (formerly called the CONSDM or CONRAD code) was used to analyze the responses of the 2-volume containment to a DBA energy release of $4000 \mathrm{MW}$-sec and a fuel vapor release of $200 \mathrm{~kg}$. The results can be compared to a DBA energy release of $8000 \mathrm{MW}-\mathrm{sec}$ and $790 \mathrm{~kg}$ of fue 1 
vapor reported previously. (1) The 2-volume containment includes the reactor cavity and the three heat transport cells. The reduced spray of fuel vapor into the cavity atmosphere reduced the initial pressure peak to only 24 psig (compared to 50 psig previously). The reduced value of excursion energy about doubled the time delay for initiation of boiling of the sodium pool on the floor of the cavity. The secondary pressure peak during the boil off of sodium from the cavity and its condensation in the cells remains the same as before, about 18 psig.

2. Sodium Pool Fire in Containment Sphere, DBA with no Machinery Dome

P. R. Shire (821)

The consequences of a hypothetical pool fire in the main containment vessel have been calculated for the case of a severe excursion accident with no machinery dome. Containment sphere initial conditions are $80^{\circ} \mathrm{F}$ and 14.7 psia. Approximately $75 \%$ of the vessel inventory or a 130 ton mass of $1050^{\circ} \mathrm{F}$ liquid sodium is assumed to be expelled from the reactor vessel. Reactor head lift following the accident accommodates the large mass expulsion. With no machinery dome, liquid sodium is assumed to come to rest in a pool covering the entire operating floor of the reactor building. Uniform mixing of core debris with vessel sodium prior to expulsion was assumed pessimistically. Therefore, $75 \%$ of core decay heat from full power $\left(400 \mathrm{MW}_{\mathrm{t}}\right)$ is carried with the sodium resulting in an initial heat input of $800 \mathrm{Btu} / \mathrm{hr} / \mathrm{ft}^{2}$ of pool surface. Heat losses from the sodium pool were to the sphere steel and environment and to the concrete operating floor. Calculation was performed with the SOFIRE code.

1. MITPR, August 1969 . 
Sphere internal pressure rose rapidly to a peak of $24.0 \mathrm{psig}$ in 8.5 minutes; air temperature was $1060^{\circ} \mathrm{F}$ while sphere stee 1 temperature was $120^{\circ} \mathrm{F}$. The run terminated at $2.8 \mathrm{hr}$ because of low oxygen concentration $(<0.05 \%)$ sphere internal pressure and temperature decreased to $8.3 \mathrm{psig}$ and $680^{\circ} \mathrm{F}$ while sphere steel temperature was at $627^{\circ} \mathrm{F}$ and rising. The rising stee 1 temperature and decreasing depleted air temperature indicated a limiting steel temperature of $650^{\circ} \mathrm{F}$.

3. Cold Sodium Insertion Analysis

C. L. Fies (821)

The insertion of cold sodium into the reactor core when the reactor is critical will result in a reactivity increase caused by the negative temperature coefficients inherent in the design. A cold sodium accident can only occur if the reactor is operating at a power level somewhat less than full power where an idle heat transport loop contains sodium at a lower temperature. The most severe cold sodium accident would occur if the reactor is placed in a condition where the average core temperature were a maximum and the heat transport system were in a condition where the maximum amount of cold sodium were available for insertion into the core. This condition, while unlikely, could occur if the reactor heat transport system were operating with only one loop to remove the decay heat from the reactor and the flow through the reactor was controlled in such a manner that a delta $T$ was present across the reactor core. A similar condition could occur if the reactor were operating under natural circulation conditions with the use of one heat transport loop. With the above considerations in mind, analyses were performed based on the following as sumptions :

- The reactor is at a low prompt power ( 1 Watt) and decay heat level is $10 \mathrm{MW}$. 
- Decay heat is being removed with one heat transport loop operating at a flow in such a manner that the full core delta $\mathrm{T}\left(600^{\circ} \mathrm{F}\right.$ to $\left.900^{\circ} \mathrm{F}\right)$ is maintained.

- The other two loops are isothermal at $350^{\circ} \mathrm{F}$.

- At time zero, the two cold loops begin pouring cold sodium into the reactor inlet plenum increasing the primary flow.

The reactor inlet plenum mixing creates an inlet temperature transient to the reactor core.

The flow and temperature transients were then combined with the following reactivity feedback terms:

$\begin{array}{lll}\text { Doppler Coefficient } & \mathrm{T} \frac{\mathrm{dk}}{\mathrm{d} t} & -0.004 \\ \text { Sodium Temperature Coefficient } & \Delta \mathrm{k} /{ }^{\circ} \mathrm{F} & -1.5 \times 10^{-6} \\ \mathrm{C} l a d \text { Expansion Coefficient } & \Delta \mathrm{k} /{ }^{\circ} \mathrm{F} & -2.5 \times 10^{-6} \\ \text { Radial Expansion Coefficient } & \Delta \mathrm{k} /{ }^{\circ} \mathrm{F} & -3.0 \times 10^{-6}\end{array}$

The reactor $\Delta \mathrm{T}$ is collapsed during the first five seconds of the transient due to the decrease in inlet temperature combined with the increase in reactor primary flow. Both the Doppler and expansion coefficients insert positive reactivity during the first $5.4 \mathrm{sec}$ of the transient. At approximately $5.4 \mathrm{sec}$ the net positive reactivity insertion approaches prompt critical and the reactor power increases. The reactor power is turned around by the Doppler and expansion feedback but then increases to approximately $250 \mathrm{MW}$ in 20 seconds. No fuel or cladding damage will occur since a reactor trip occurs near $5.4 \mathrm{sec}$ as a result of the power spike. 
BNWL - 1246

APPENDIX A

AUTHOR CODES FOR FFTF PERIODIC TECHNICAL REPORTS

(Effective 9-16-69) 
APPENDIX A

AUTHOR CODES FOR FFTF PERIODIC TECHNICAL REPORTS

(Effective 9-16-69)

$\underline{\text { Code }}$

A00

$\mathrm{COO}$

KOO

MOO

NOO

390

391

392

393

394

395

400

410

420

600

610

620

630

700

Author's Organization

BNW Chemistry \& Metallurgy Division

BNW Physics \& Engineering Division

BNW Environmental \& Life Sciences Division

BNW Systems \& Electronics Division

FFTF Division, E. R. Astley, J. C. Cochran

FFTF Administration Department - H. E. Little

Contract Negotiations - J. C. Richardson

Procurement - R. J. Gandy

Data \& Support Services - J. R. Boldt

Reports \& Publications - J. F. Erben

FFTF Finance - L. A. Jones

FFTF Quality Assurance Dept. - R. J. Squires

QA Program Planning \& Requirements

QA Program Audit \& Evaluation

FFTF Construction Department - J. S. McMahon

Construction Engineering - C. E. Love

Engr. Administration \& Contro1 - H. E. Hylbak

Construction Engr. \& Inspection

FFTF Fuels Dept. - E. A. Evans, W. E. Roake,

T. W. Evans

710 Offsite Fue1 Programs - G. A. Last

711 LMFBR Fuel Dev. - B. R. Hayward

712 FFTF Fue1 Procurement

720

Cladding Development - T. T. Claudson

721 Cladding Dev. \& Procurement - J. C. Tverberg

722 Cladding Evaluation - J. J. Holmes

723 Fue1 \& C1adding Info. Center

Fuel Element Dev. - C. A. Burgess 
731 Process Dev. \& Demonstration - R. E. Bardsley

732 Subassembly Dev. - J.W. Thornton

733 Special Products Fab. - E. T. Weber

Fuels Qual. Assurance - H. G. Powers

750

Fuels Evaluation - J. E. Hanson

760

800

Fuel Cycle Analysis - A. W. Demerschman

FFTF Reactor \& Plant Technology Dept. -

P. L. Hofmann, D. E. Simpson

810

Reactor \& Plant Engr. - L. M. Finch

811 Reactor Engineering - D. Marinos

812 Plant Engineering - D. P. Schively

813 Radiation \& Shield Analysis - W. L. Bunch Safety \& Systems Analysis - R. E. Peterson

821 Safety Analysis - D. D. Stepnewski

822 Systems Analysis - H. G. Johnson

823 Control Analysis - R. A. Harvey

824 Rad. E Environ. Safety

825 Safety Tech. \& Practices

830 Nuclear \& Process Tech. - R. E. Heineman

831 Nuclear Analysis - W. W. Little

832 Core Analysis - P. D. Cohn

833 Exper. Physics - R. A. Bennett

834 Operations - D. C. Boyd

835 Process Analysis

900 FFTF Engineering Department - D. L. Condotta,

F. C. Gronemeyer, W. B. McDonald

910 Reactor Design - S. O. Arneson

911 Specialists

912 Reactor Components - R. C. Walker

913 Core Engineering - J. F. Wett

914 Equipment Engineering - C. A. Munro

920 Fluid Systems - J. M. Batch

921 Specialists 
922 Sodium Technology - W. R. Wykoff

923 Heat Removal System - T. W. Withers

924 Test Systems - P. F. Shaw

925 Auxiliary Systems - R. V. Dulin

931 Tech. Staff

932 Reactor Instrumentation - R. R. Cone

933 Plant Instrumentation - J. W. Mitchell

Facilities \& Site - E. M. Johnston

941 Structures \& Utilities - F. H. Shade1

942 Fuel Examination - C. L. Boyd

943 Electrical Systems - G. H. Strong

950 Engr. Coordination \& Planning - J. R. Carre11

951 Tech. Staff

952 Design Procedures \& Control - H. D. Lenkersdorfer

953 Project Scheduling - D. R. Doman

954 Development \& Test Coordination - K. G. Toyoda

960 Metals, Materials \& Codes - J. C. Tobin

961 Technical Staff

962 Fabrication Development

963 Materials Application

964 Surveillance Program

970 Engineering Q.A. \& Standards - J. A. Perry 


\section{DISTRIBUTION}

No. of

Copies

OFFS ITE

AEC Division of Reactor Development and Technology*

M. Shaw, Director, RDT

Asst Dir for Nuclear Safety

Analysis \& Evaluation Br, RDT:NS

Environmental \& Sanitary Engrg Br, RDT:NS

Research \& Development Br, RDT:NS

Asst Dir for Plant Engrg, RDT

Facilities $\mathrm{Br}$, RDT : PE

Components $\mathrm{Br}, \mathrm{RDT}: \mathrm{PE}$

Instrumentation \& Control $\mathrm{Br}, \mathrm{RDT}: \mathrm{PE}$

Liquid Metal Systems Br, RDT:PE

Asst Dir for Program Analys is, RDT

Asst Dir for Project Mgmt, RDT

Liquid Metals Project Br, RDT:PM

FFTF Project Manager, RDT:PM (3)

Asst Dir for Reactor Engrg, RDT

Control Mechanisms Br, RDT:RE

Core Design Br, RDT:RE (2)

Fue 1 Engineering $\mathrm{Br}$, RDT:RE

Fuel Handling $\mathrm{Br}$, RDT: RE

Reactor Vessels Br, RDT:RE

Asst Dir for Reactor Tech, RDT

Coolant Chemistry $\mathrm{Br}$, RDT:RT

Fuel Recycle $\mathrm{Br}$, RDT:RT

Fuels \& Materials Br, RDT:RT

Reactor Physics Br, RDT:RT

Special Technology Br, RDT:RT

Asst Dir for Engrg Standards, RDT

EBR-II Project Manager, RDT:PM

AEC Idaho Operations office*

Nuclear Technology Division

C. W. Bills,Director

1

AEC San Francisco Operations Office * Director, Reactor Division

* Distribution by FFTF 
No. of

Copies

4

$\frac{\text { AEC Site Representatives }}{\text { Argonne National Laboratory }}$

Atomics International

Atomic Power Development Assoc.

General Electric Co.

1 Aerojet General Corporation

R. L. Murray, Project Manager

1 Rockwe11 Manufacturing Company

W. T. Gettig, Gov. Contract Admin.

1 The Crane Company

R. C. Murphy, Project Engineer

10 Bechte1 Corporation*

J. J. Teachnor, Project Administrator, FFTF

15 Westinghouse Electric Corporation*

Atomic Power Division

Advanced Reactor Systems

D. C. Spencer

1 AEC Chicago Patent Group

G. H. Lee

2

3 Argonne National Laboratory

R. A. Jaross

LMFBR Program Office

N. J. Swanson

1 Atomic Power Development Associates

Document Librarian

$7 \quad$ Atomics International

FFTF Program Office (5)

Liquid Metal Information Center - A. E. Miller (2)

* Distribution by FFTF 
No. of

Copies

2

Babcock \& Wilcox Co.

Atomic Energy Division

S. H. Esleeck

G. B. Garton

1

BNW Representative

R. M. Fleischman (ZPPR)

1 Combustion Engineering

1000 MWe Fo11ow-on Study

W. P. Staker, Project Manager

1 Combustion Engineering

Mrs. Ne11 Holder, Librarian

5

General Electric Co.

Advanced Products Operation

Karl Cohen (3)

Nuclear Systems Programs

D. H. Ahmann (2)

2 Gulf General Atomic Inc. General Atomic Division

D. Coburn

1 Idaho Nuclear Corporation

D. R. DeBoisblanc

$1 \quad$ Liquid Metal Engineering Center

R. W. Dickinson

1 Oak Ridge National Laboratory

W. O. Harms

$1 \quad$ Stanford University

Nuclear Division

Division of Mechanical Engineering

R. Sher 
No. of

Copies

United Nuclear Corporation

Research and Engineering Center

R. F. DeAnge 1is

ONSITE - HANFORD

1

AEC Chicago Patent Group

R. K. Sharp (Richland)

$\underline{\text { Battelle Memorial Institute }}$

Batte $11 \mathrm{e}-$ Northwest

F. W. Albaugh

G. J. A1kire

S. O. Arneson

J. M. Batch

A. L. Bement, Jr.

R. A. Bennett

T. K. Bierlein

L. D. Blackburn

C. L. Boyd

R. L. Brown

W. L. Bunch

C. A. Burgess

J. J. Cadwe 11

A. C. Callen

C. M. Cantre11

J. R. Carre11

T. D. Chikalla

T. T. Claudson

P. D. Cohn

J. H. Cox

G. M. Dalen

J. M. Davidson

F. G. Dawson

D. R. de Halas

A. W. DeMerschman

D. R. Doman

G. E. Driver

K. Drumbeller

R. V. Dulin

T. W. Evans

P. L. Farnsworth

L. M. Finch
J. C. Fox

E. E. Garrett

W. L. Hampson

J. E. Hanson

K. M. Harmon

H. Harty

R. A. Harvey

B. R. Hayward

R. E. Heineman

J. W. He $1 \mathrm{~m}$

R. J. Hennig

G. M. Hesson

J . J . Holmes

H. G. Johnson

E. M. Johnston

J. N. Judy

F. J. Kempf

G. A. Last

D. C. Lehfe1dt

H. D. Lenkersdorfer

C. W. Lindenmeier

W. W. Little, Jr.

C. E. Love

B. Mann

D. Marinos

C. A. Munro

R. E. Nightingale

L. T. Pedersen

G. S. Petersen

R. E. Peterson

H. G. Powers

H. S. Pringle 
Battelle-Northwest (contd)
W. D. Richmond
W. E. Roake
M. Voge 1
R. L. Roske
R. C. Walker
L. C. Schmid
E. T. Webber
F. H. Shadel
J. H. Westsik
D. W. Shannon
J. F. Wett
F. R. Shober
R. G. Wheeler
D. E. Simpson
F. J. Williams
C. R. F. Smith
N. G. Wittenbrock
D. D. Stepnewski
T. W. Withers
G. H. Strong
M. R. Wood
C. D. Swanson
F. W. Woodfield
J. W. Thornton
D. C. Worlton
J. C. Tobin
K. G. Toyoda
J. C. Tverberg
H. H. Yoshikawa
Technical Information (5)
C. E. Voge 1
Technical Publications (3)
Legal-703 B1dg.
Legal-ROB, 221-A

AEC Program Office-PNL*

T. A. Nemzek

AEC Richland Operations Office*

J. M. Shivley

Bechte1 Corporation*

M. 0. Rothwe 11

1

Westinghouse Electric Corporation*

R. Strzelecki (Richland)

27

Battelle-Northwest*

E. R. Astley

C. P. Cabe11 (2)

J. C. Cochran

D. L. Condotta

C. T. Davis

J. F. Erben

E. A. Evans

F. C. Gronemeyer

P. L. Hofmann
H. E. Little

W. B. McDonald

J. S. McMahon

P. F. Shaw

R. J. Squires

W. R. Wykoff

FFTF Files (10)

FFTF TPO Files (List "M")

Distribution by FFTF 
1

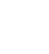

